Key Words: Phytoremediation, $\mathrm{Ac}, \mathrm{Co}, \mathrm{Cr}, \mathrm{Hg}, \mathrm{Pb}, \mathrm{Ra}, \mathrm{Th}$, U, Stabilization, Wetlands, Apatite, Zeolite, Metallic Iron, Water Oak, Tupelo, Cypress, Loblolly Pine, Red Maple, Ferns

Retention: Permanent

\title{
Proof-of-Concept of the Phytoimmobilization Technology for TNX Outfall Delta: Final Report
}

\author{
Daniel I. Kaplan ${ }^{(1)}$, Anna S. Knox ${ }^{(2)}$, Thomas G. Hinton ${ }^{(2)}$, \\ Rebecca R. Sharitz ${ }^{(2)}$, Bruce P. Allen ${ }^{(2)}$, Steven M. Serkiz ${ }^{(1)}$ \\ (1) Westinghouse Savannah River Company \\ (2) Savannah River Ecology Laboratory
}

March 19, 2001

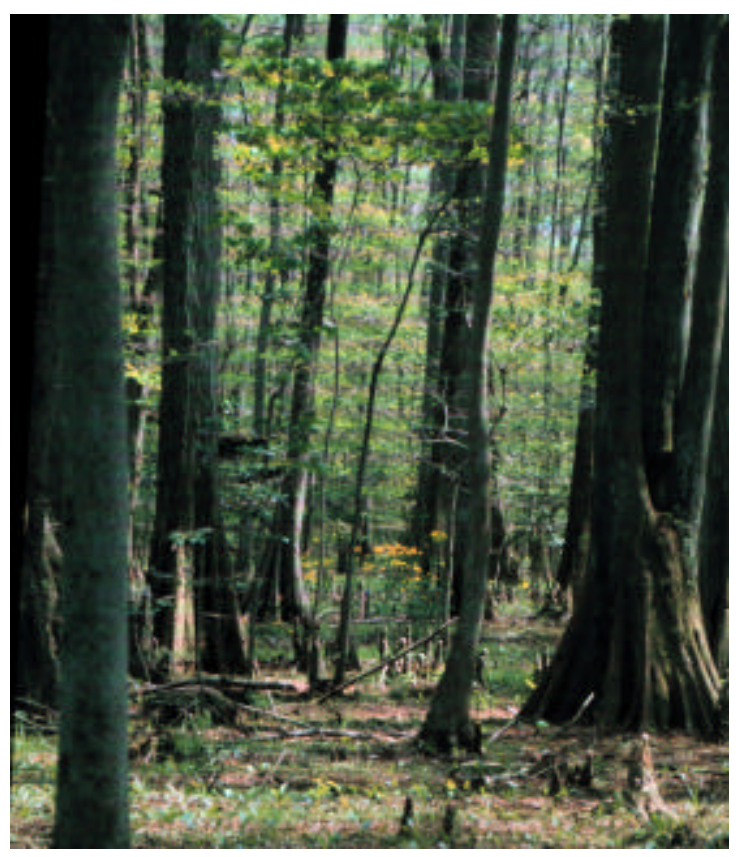

Westinghouse Savannah River Company

Savannah River Site

Aiken, SC 29808

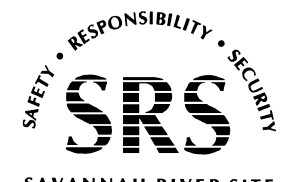

Prepared for the U.S. Department of Energy Under

Contract Number DE-AC09-96SR18500 
This document was prepared in conjunction with work accomplished under Contract No.

DE-AC09-96SR18500 with the U.S. Department of Energy.

\section{DISCLAIMER}

This report was prepared as an account of work sponsored by an agency of the United States Government. Neither the United States Government nor any agency thereof, nor any of their employees, makes any warranty, express or implied, or assumes any legal liability or responsibility for the accuracy, completeness, or usefulness of any information, apparatus, product or process disclosed, or represents that its use would not infringe privately owned rights. Reference herein to any specific commercial product, process or service by trade name, trademark, manufacturer, or otherwise does not necessarily constitute or imply its endorsement, recommendation, or favoring by the United States Government or any agency

thereof. The views and opinions of authors expressed herein do not necessarily state or reflect those of the United States Go vernment or any agency thereof.

This report has been reproduced directl y from the best available copy.

Available for sale to the public, in paper, from: U.S. Department of Commerce, National Technical Information Service, 5285 Port Roy al Road, Springfield, VA 22161, phone: (800)

553-6847, fax: (703) 605-6900, email: orders@ntis.fedworld.gov online ordering: http://www.ntis.gov/ordering.htm

Available electronically at http://www.doe.gov/bridge

Available for a processing fee to U.S. Department of Energy and its contractors, in paper, from: U.S. Department of Energy, Office of Scientific and Tech nical Information, P.O. Box 62, Oak Ridge, TN 37831-0062, phone: (865 ) 576-8401, fax: (865) 576-5728, email: reports@adonis.osti.gov 
Key Words: Phytoremediation, $\mathrm{Ac}, \mathrm{Co}, \mathrm{Cr}, \mathrm{Hg}, \mathrm{Pb}, \mathrm{Ra}$, Th, U, Stabilization, Wetlands, Apatite, Zeolite, Metallic Iron, Water Oak, Tupelo, Cypress, Loblolly Pine, Red Maple, Ferns Retention: Permanent

\title{
Proof-of-Concept of the Phytoimmobilization Technology for TNX Outfall Delta: Final Report
}

\author{
Daniel I. Kaplan ${ }^{(1)}$, Anna S. Knox ${ }^{(2)}$, Thomas G. Hinton ${ }^{(2)}$, \\ Rebecca R. Sharitz ${ }^{(2)}$, Bruce P. Allen ${ }^{(2)}$, Steven M. Serkiz ${ }^{(1)}$ \\ (1) Westinghouse Savannah River Company \\ (2) Savannah River Ecology Laboratory
}

March 19, 2001

Westinghouse Savannah River Company

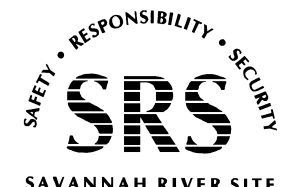

Prepared for the U.S. Department of Energy Under 


\section{REVIEWS AND APPROVALS}

Daniel I. Kaplan, Co-author, Waste Processing Technology

Date

Anna S. Knox, Co-author, Savannah River Ecology Laboratory

Date

Thomas G. Hinton, Co-author, Savannah River Ecology Laboratory

Date

Rebecca R. Sharitz, Co-author, Savannah River Ecology Laboratory

Date

Bruce P. Allen, Co-author, Savannah River Ecology Laboratory

Date

Steven M. Serkiz, Co-author, Waste Processing Technology

Date

B. Thomas Butcher, Level 4 Manager, Waste Processing Technology

Date

Gary Iversen, Design Check, Waste Processing Technology

Date

Page 2 


\section{TABLE OF CONTENTS}

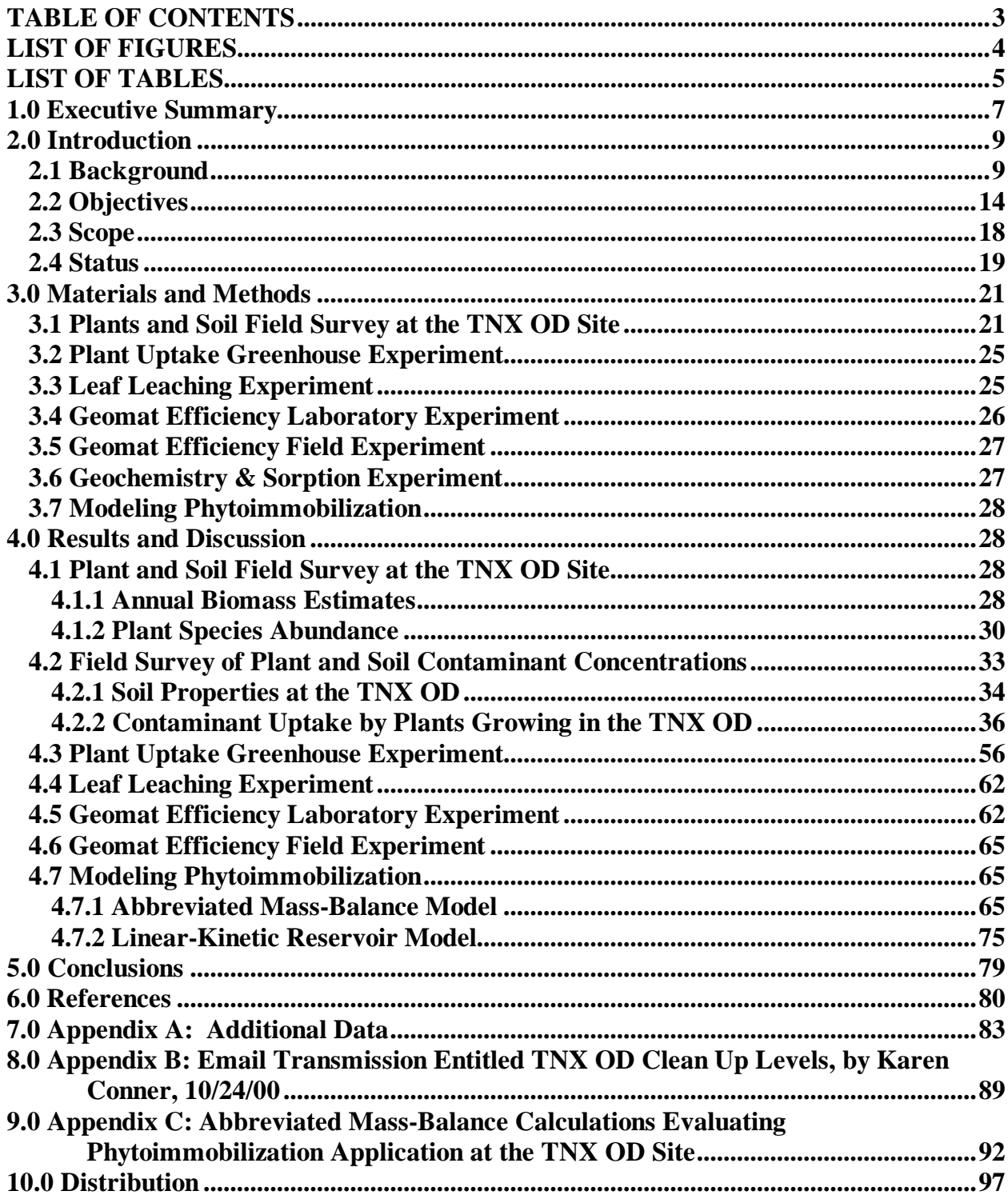




\section{LIST OF FIGURES}

Figure 1. Simplified cross sectional view of the TNX Outfall Delta operable unit.

Figure 2. First step in phytoimmobilization, phytoextraction, involves extraction of the sediment contaminant, followed by translocation of the contaminant into the above ground plant parts.

Figure 3. Second step in phytoimmobilization, sequestration, involves immobilizing the contaminants leached from plant litter material within a sequestering agent.

gure 4. Emplacement of the sequestering agent can be either (A), incorporated into the contaminated sediment surface, or (B) in the geomat configuration.

gure 5. Contaminant reservoirs included in the linear-kinetic reservoir model...... 14

Figure 6. Example of the type of output that the linear-kinetic reservoir model produces (COC stands for constituent of concern).

Figure 7. Experiments conducted and their relation to the linear-kinetic reservoir model....18

Figure 8. Plant tissue and soil sampling locations at the TNX OD.................................23

Figure 9. Litter Basket locations at the TNX-OD. ..........................................................24

Figure 10. Elemental concentrations in netted-chain ferns as a function of harvesting date. 55

Figure 11. Predicted soil Ra-228 activity as a function of years of phytoimmobilization remediation at the TNX OD site (volume of remediated soil $=4214 \mathrm{~m}^{3}$; target $10 \mathrm{e}-6$ risk clean up level indicated with dotted line).

Figure 12. Predicted soil $\mathrm{Pb}-212$ activity as a function of years of phytoimmobilization remediation at the TNX OD site (volume of remediated soil $=4214 \mathrm{~m}^{3}$; target $10 \mathrm{e}-6$ risk clean up level indicated with dotted line).

Figure 13. Predicted soil Th-228 activity as a function of years of phytoimmobilization remediation at the TNX OD site (volume of remediated soil $=4214 \mathrm{~m}^{3}$; target $10 \mathrm{e}-6$ risk clean up level indicated with dotted line).

Figure 14. Predicted soil U-235 activity as a function of years of phytoimmobilization remediation at the TNX OD site (volume of remediated soil $=4214 \mathrm{~m}^{3}$; target $10 \mathrm{e}-6$ risk clean up level indicated with dotted line).

Figure 15. Predicted soil U-238 activity as a function of years of phytoimmobilization remediation at the TNX OD site (volume of remediated soil $=4214 \mathrm{~m}^{3}$; target $10 \mathrm{e}-6$ risk clean up level indicated with dotted line).

Figure 16. Predicted soil Ac-228 activity as a function of years of phytoimmobilization remediation at the TNX OD site (volume of remediated soil $=4214 \mathrm{~m}^{3}$; target $10 \mathrm{e}-6$ risk clean up level was not calculated). ........................................................................... 74

Figure 17. Linear-kinetic Reservoir Model of Phytoimmobilization at the TNX OD Site....76 


\section{LIST OF TABLES}

Table 1. Status and reporting of project tasks.

Table 2. Experimental matrix for the Geomat Efficiency Field Experiment. .........................2 27

Table 3. Leaf litter mass collected on March 15, 2000 from sampling baskets placed in 40 locations in the contaminated area and 6 locations in the uncontaminated area. ............29

Table 4. Annual leaf-litter biomass estimates for leaves at the TNX OD.............................30

Table 5. Species-composition of leaf litter (wt-\%) (Table continues in Table 6)..................31

Table 6. Specie-composition of leaf litter (\%-g species/100-g total leaf litter) (Table continues in Table 5).

Table 7. Mass of leaves of plant species collected from 21-leaf litter baskets located in the contaminated portion of the TNX OD.

Table 8. Soil characterization of an uncontaminated background soil collected from coordinate BGCH05 and a contaminated soil collected from coordinate A-5 ................35

Table 9. Elemental Composition $(\mu \mathrm{g} / \mathrm{g})$ of an uncontaminated background soil collected from coordinate $\mathrm{BGCH} 05$ and a contaminated soil collected from coordinate A-5 ................35

Table 10. Elemental composition and total concentration ratio (plant concentration/total soil concentration) of plants collected from coordinate A-5 within the TNX OD on November 11, 1999

Table 11. Correlation coefficients ( $\mathrm{r}$ ) between concentration ratios and soil concentrations. 37

Table 12. COCs concentrations ( $\mathrm{mg} / \mathrm{kg}$ dry wt.) of leaves recovered from the TNX-OD study site (table continues on next page).

Table 13. Correlation coefficients ( $\mathrm{r}$ ) between $\mathrm{Mn}$ or Fe and COC total concentration ratios (CR-T).

Table 14. Total soil and plant concentrations ( $\mathrm{mg} / \mathrm{kg}$; dry wt.) and total concentration ratios (CR-T; plant conc./total soil conc.) (table continues on following page)........................44

Table 15. Average total concentration ratios (CR-T; plant conc./total soil conc.) values. ....47

Table 16. COC concentrations ( $\mathrm{mg} / \mathrm{kg}$; dry weight) and total concentration ratios (CR-T; plant conc./total soil conc.) from leaves and soils collected from coordinate A-5 at the TNX-OD study site.

Table 17. COC concentrations ( $\mathrm{mg} / \mathrm{kg}$; dry weight) and total concentration ratios (CR-T; plant conc./total soil conc.) from leaves and soils collected from coordinate B-3 at the TNX-OD study site.

Table 18. COC concentrations ( $\mathrm{mg} / \mathrm{kg}$; dry weight) and total concentration ratios (CR-T; plant conc./total soil conc.) from leaves and soils collected from coordinate C-5 at the TNX-OD study site.

Table 19. COCs concentration in four fern plants $(\mathrm{mg} / \mathrm{kg}$; dry weight) collected at the TNX OD study site.

Table 20. Total concentration ratios (plant conc./total soil conc.) in four fern plants collected at the TNX OD study site.

Table 21. Greenhouse study of netted-chain fern in non-contaminated background soil: total soil (Soil-T) and available soil (Soil-A) COC concentrations $(\mathrm{mg} / \mathrm{kg})$, tissue concentrations $(\mathrm{mg} / \mathrm{kg})$, and concentration ratios (CR-T; plant conc./soil conc.).. 
Table 22. Greenhouse study of netted-chain fern in contaminated B-5 soil: total soil (Soil-T) and available soil (Soil-A) COC concentrations $(\mathrm{mg} / \mathrm{kg})$, tissue concentrations $(\mathrm{mg} / \mathrm{kg})$, and concentration ratios (CR-T; plant conc./soil conc.).

Table 23. Greenhouse study of netted-chain fern in contaminated C-5 soil: total soil (Soil-T) and available soil (Soil-A) COC concentrations $(\mathrm{mg} / \mathrm{kg})$, tissue concentrations $(\mathrm{mg} / \mathrm{kg})$, and concentration ratios (CR-T; plant conc./soil conc.).

Table 24. Greenhouse study of Bermuda grass in non-contaminated background soil: total soil (Soil-T) and available soil (Soil-A) COC concentrations ( $\mathrm{mg} / \mathrm{kg}$ ), tissue concentrations $(\mathrm{mg} / \mathrm{kg})$, and concentration ratios (CR-T; plant conc./soil conc.).

Table 25. Greenhouse study of Bermuda grass in contaminated B-5 soil: total soil (Soil-T) and available soil (Soil-A) COC concentrations $(\mathrm{mg} / \mathrm{kg})$, tissue concentrations $(\mathrm{mg} / \mathrm{kg})$, and concentration ratios (CR-T; plant conc./soil conc.).

Table 26. Greenhouse study of Bermuda grass in contaminated C-5: total soil (Soil-T) and available soil (Soil-A) COC concentrations $(\mathrm{mg} / \mathrm{kg})$, tissue concentrations $(\mathrm{mg} / \mathrm{kg})$, and concentration ratios (CR-T; plant conc./soil conc.).

Table 27. Chromium distribution coefficients $(\mathrm{Kd})$ for several sequestering agents in a SRS surface water.

Table 28. Effect of sequestering materials on aqueous $\mathrm{Hg}$ concentration. ${ }^{(a)}$......

Table 29. Kd values (mL/g) of $\mathrm{Co}, \mathrm{Ba}, \mathrm{Eu}, \mathrm{Pb}$, and $\mathrm{U}$ for various potential sequestering agent materials. ${ }^{(a)}$

Table 30. Current soil inventory ( $\mathrm{I}_{\text {current soil }}$; Equation 3 ), allowable soil inventory, annual contaminant reduction in the soil $\left(\mathrm{ACR}_{\text {total }}\right.$; Equation 7$)$ and the number of years necessary to accomplish clean up to $10 \mathrm{e}-6$ risk levels.

Table 31. Preliminary input values for the Linear-kinetic Reservoir Model of Phytoimmobilization (additional input in next table).

Table 32. Preliminary input values for the Linear-kinetic Reservoir Model of Phytoimmobilization (additional input in previous table).

Table 33. Scientific names of several plants referred to in this report.................................. 84

Table 34. Available soil (Soil-A) and plant concentrations ( $\mathrm{mg} / \mathrm{kg}$; dry weight) and available concentration ratios (CR; plant conc./available soil conc.).

Table 35. Average available concentration ratios (CR-A; plant conc./available soil conc.) values.

Table 36. Current and allowable soil activity at the study site ........................................93

Table 37. Current soil inventory ( $\mathrm{I}_{\text {current soil }}$; Equation 1 ) of selected isotopes......................93

Table 38. Netted-chain fern and leaf litter activity levels $\left(\mathrm{A}_{\text {plant } i}\right)$ based on soil activity $\left(\mathrm{A}_{\text {current soil }}\right)$ and concentration ratio $\left(\mathrm{CR}_{\text {plant } i}\right)$ data (Equation 2$)$.

Table 39. Netted-chain fern and leaf-litter isotope inventory $\left(\mathrm{I}_{\text {plant } i}\right.$; Equation 3$)$............... 94

Table 40. Annual contaminant reduction $\left(\mathrm{ACR}_{\text {plant } i}\right.$; Equations 4 and 5) in soils as a result of plant uptake (inventory in plant/inventory in soil).

Table 41. Total inventory allowed based on $10 \mathrm{e}-6$ risk. ................................................95 


\subsection{EXECUTIVE SUMMARY}

A series of proof-of-principle studies was initiated to evaluate the soil remediation technology, phytoimmobilization, for application at the TNX Outfall Delta (TNX OD) operable unit. Phytoimmobilization involves two steps. The first step is entitled phytoextraction, and it takes place mostly during the spring and summer. During this step the plants extract contaminants from the sediment into the roots and then translocate the contaminants to the aboveground plant parts. The second step is referred to as sequestration and it takes place largely during the autumn and winter when annual plants senesce or deciduous trees drop their leaves. This step involves the immobilization of the contaminant once it leaches form the fallen leaves into a "geomat," a geotextile embedded with mineral sequestering agents. This final report describes the results to date, including those reported in the status report (Kaplan et al. 2000a), those completed since the report was issued, and the preliminary calculations of the phytoimmobilization effectiveness.

Leaf litter at the site was found to contain measurable concentrations of the constituents of concern (COCs; actinium, cobalt, chromium, mercury, lead, radium, thorium and uranium). Equally important, the leaf litter at the site was found to have a large annual biomass, $>7000$ $\mathrm{kg} / \mathrm{ha} / \mathrm{yr}$. As part of a survey of the indigenous plants at the test site, it was discovered that the netted-chain fern (Woodwardia areolata) contained exceptionally high contaminant concentrations of cobalt, cerium (an analog for actinium) and chromium. Contaminant concentrations in netted-chain ferns were found to vary with the seasons. During the spring, when plant growth was greatest, all contaminant plant concentrations were their lowest. During the autumn, the season when the leaves (or in the case of ferns, the fronds) come into contact with the geomat, the contaminant plant concentrations were their greatest. This trend in plant concentration is ideal for the phytoimmobilization technology. Among the more abundant trees at the site, tupelo (Nyssa sylvatica var. biflora) was found to take up high concentrations of barium (an analog for radium), cobalt, and thorium.

Greenhouse studies were conducted in which netted-chain ferns were grown in contaminated soils collected from the TNX OD operable unit. The netted-chain fern took up appreciably greater concentrations of essentially all contaminants than a grass (Bermuda grass, Cynnodon dactylon). The fern hyperaccumulated cobalt (defined as having a concentration ratio [plant concentration/soil concentration] greater than unity) and had exceptionally high uptake ratios of cadmium, chromium, cesium, mercury, lead and uranium (concentration ratios between 0.1 and 1$)$.

Laboratory studies were conducted to evaluate various sequestering agents. Pyrite, a sulfide mineral, was found to have a distribution coefficient (Kd value) of $20,000 \mathrm{~mL} / \mathrm{g}$ for mercury. Hydroxyapatite, a phosphate source, was able to remove large amounts of cobalt $(\mathrm{Kd}=7700$ $\mathrm{mL} / \mathrm{g}$ ), europium (an analogue for actinium; $\mathrm{Kd}=720,000 \mathrm{~mL} / \mathrm{g})$, lead $(\mathrm{Kd}=138,000 \mathrm{~mL} / \mathrm{g}$ ), and uranium $(\mathrm{Kd}=282,000 \mathrm{~mL} / \mathrm{g})$. Clinoptilolite, a zeolite cation exchange mineral, effectively removed barium (an analogue for radium; $\mathrm{Kd}=6200 \mathrm{~mL} / \mathrm{g}$ ). A field demonstration of the various sequestering agents was set up at the TNX OD site, but the project was terminated prior to collecting the first year's data. 
The first year's status report (Kaplan et al. 2000a) concluded that a manner in which phytoimmobilization might be deployed at the site was to use the existing trees and plant additional netted-chain ferns. The existing trees would have a high litter biomass, but only moderate contaminant concentrations. The ferns would produce less biomass, but would have appreciably greater contaminant concentrations. The sequestering agents would consist of a combination of hydroxyapatite, clinoptilolite, and a sulfide source. Pieces of geomat, made up of sequestering agent embedded between two pieces of geofabric, would be used to deploy the sequestering agents around the existing trees and the planted ferns. The contaminant survey and greenhouse results obtained since the status report was issued support this approach of deployment with the modification that tupelo trees should also be planted to increase the annual leaf-litter biomass and uptake by leaves.

A mass balance calculation was conducted with the available site-specific data to provide an early estimate of the efficacy of the proposed phytoimmobilization scheme. In these calculations, it was assumed that the amount of contaminant remediated would incrementally decrease over time, thereby diminishing the error of extrapolating long-term estimates based on short-term experimental results. Based on these conservative estimates, Th-232, Th-234, and U-233 already exist at levels well below the 10e-6 risk level and therefore do not require remediation. The remaining risk drivers at the site are $\mathrm{Ra}-228, \mathrm{~Pb}-212$, Th-228, U-235, and U-238. Ra-228 could be cleaned up to below 10e-6 risk levels within 52-years; Pb-212, Th228 , U-235, and U-238 would require $>300$-years. Another set of calculations was conducted using increased, readily achievable, annual biomass input values. In addition to cleaning up Ra-228, these calculations indicated that $\mathrm{Pb}-212$ and U-235 could be cleaned up to $10 \mathrm{e}-6$ risk levels within 183 and 298 years, respectively. Th-228 and U-238 would not be cleaned within 300-years of phytoimmobilization. A final set of calculations was conducted using a lower clean up requirement based on a 10e-5 risk level. The risk levels upon which clean up levels are based have not been established yet, but a risk level of 10e-5 is very probable in light of the fact that an industrial worker, one of the possible risk receptors, has a risk level of 10e-3. All the contaminants included in the 10e-5 risk-level calculations, except Th-228, could be clean with phytoimmobilization within 10 years or did not require remediation.

There are very few remediation options for ecologically sensitive wetland areas. Application of phytoimmobilization at the TNX OD site has a number of attributes, but also an important limitation, namely that it will likely not clean up the site of all radionuclides. Among its attributes, phytoimmobilization uses existing natural geocycling processes and simply interrupts these processes by accumulating the contaminants in the geomat. Additionally, it should greatly reduce the cost of waste disposal by creating a concentrated waste in the sequestering agent. However, the fact that not all the contaminants will be cleaned in a timely manner compromises its utility, thereby requiring that we further evaluate other remediation approaches and/or the clean up goals of the site. 


\subsection{INTRODUCTION}

\subsection{BACKGROUND}

The TNX pilot-scale research facility located on the Savannah River Site, released process waste into an unlined seepage basin between 1958 and 1980. The basin, referred to as the Old TNX Seepage Basin, was designed to contain wastewater until it could seep into the underlying sediments, which would then act to impede contaminant migration. The waste discharged to the Old TNX Seepage Basin included large quantities of $\mathrm{Cr}, \mathrm{Hg}, \mathrm{Na}$ compounds, depleted $\mathrm{U}, \mathrm{Th}$, and other radionuclides and heavy metals. The basin contents are believed to have entered the nearby inner and outer swamps on the flood plains of the Savannah River by subsurface flow and overland flow; a result of purposely breaching a basin wall and routinely overfilling the basin (Figure 1).

The constituents of concern (COC) at the operable unit include $\mathrm{Ac}, \mathrm{Co}, \mathrm{Cr}, \mathrm{Hg}, \mathrm{Pb}, \mathrm{Ra}$, Th and $\mathrm{U}$. These contaminants are concentrated primarily in the upper $30-\mathrm{cm}$ of sediment in the Inner Swamp area (WSRC 1999). A large portion of the operable unit is designated as a wetland. As such, the approaches applicable to remediating the site are limited due to the ecologically sensitive nature of the site. Among the most promising approaches to remediating the site are: 1) soil mixing, which involves mixing a sequestering agent into the contaminated sediment, 2) monitored natural attenuation, which involves monitoring that the contaminants do not move off site, 3) phytoremediation, a broad term referring to any form of remediation in which plants are involved, and 4) returning the site to its natural wetter condition by installing engineered earthen ridges to restrict water movement off site and then imposing monitored natural attenuation on the geochemically reduced site.

The subject of this report is the evaluation of a new form of phytoremediation referred to as phytoimmobilization for application at the TNX OD operable unit. Phytoimmobilization involves two steps. The first step is entitled phytoextraction, and it takes place mostly during the spring and the summer. During this step, plants extract contaminants from the sediment into the roots and then translocate the contaminants to the aboveground plant parts (Figure 2 ). The second step is referred to as sequestration and it takes place during the autumn and winter (Figure 3). This involves the immobilization of the contaminant once it leaches from the fallen leaf or senescent plants during the autumn. 


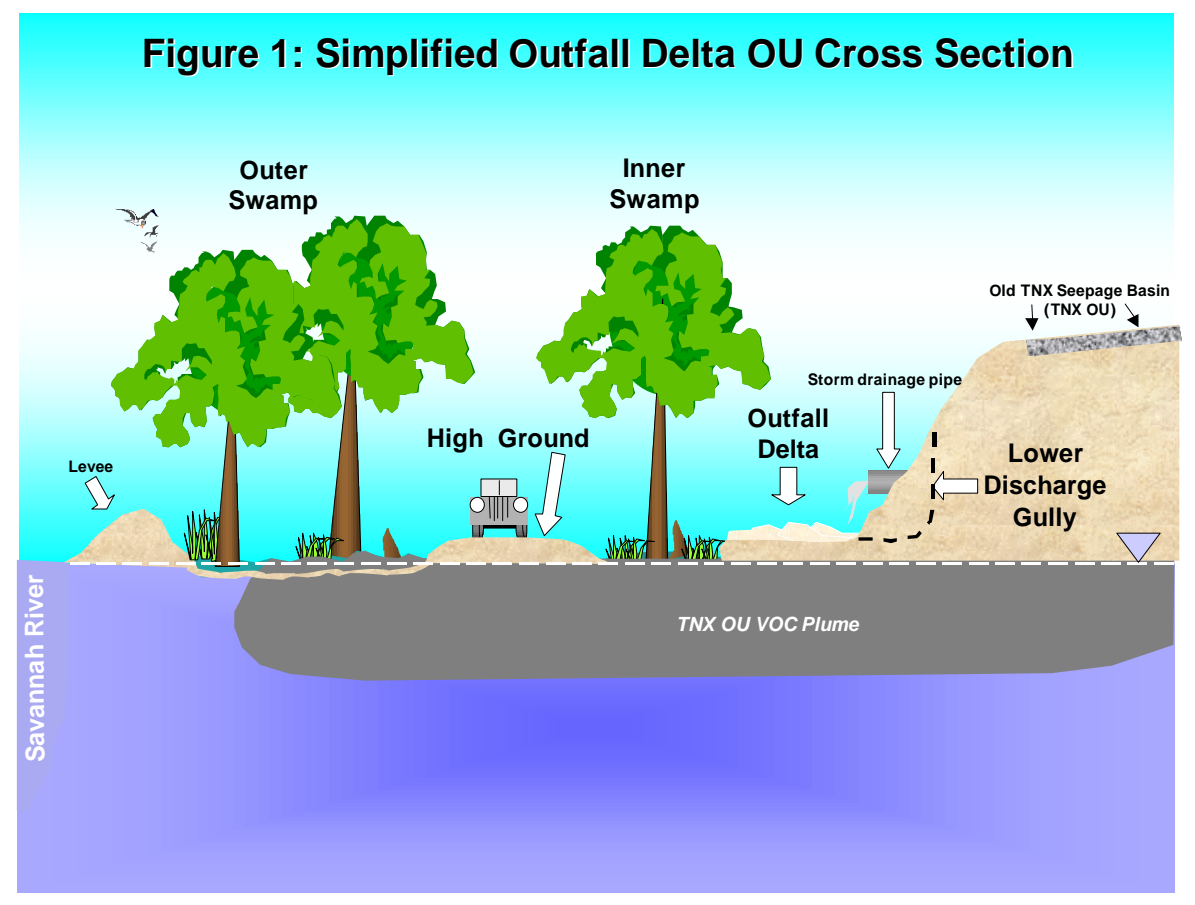

Figure 1. Simplified cross sectional view of the TNX Outfall Delta operable unit. 
The sequestering agent used in this technology should have a number of qualities; it should:

- remove the targeted contaminant(s) in the presence of leaf-leachate,

- immobilize the contaminants for a sufficient amount of time, and

- not release undesirable constituents from its matrix into its surroundings.

The sequestering agent can be emplaced by mixing into the surface sediment, or as a geomat (Figure 4). A geomat consists of a sequestering agent placed in between two sheets of a geotextile. The advantage of the geomat configuration is that it can be removed. The advantage of the soil-mixing configuration is that no labor is required to make and remove the geomat. Other considerations regarding which configuration to use include the end use of the contaminated site and the risk associated with leaving the sequestered contaminants in place.

There are a number of different materials that can be used as sequestering agents (reviewed by Cantrell and Kaplan 1998). The criteria for selecting a sequestering agent will depend on the contaminants and the chemical composition of the background solution; in this case, the background solution is plant leachate. Examples of potential sequestering agents include apatite (a calcium phosphate mineral) for $\mathrm{Pb}, \mathrm{Cd}$, $\mathrm{Th}$, and $\mathrm{U}$, and sulfide minerals for $\mathrm{Hg}, \mathrm{Sn}$, and $\mathrm{Ag}$.

The two most important attributes of phytoimmobilization are that it has minimal environmental impact on the site, and that it concentrates the waste. This latter point is especially important when compared to conventional phytoextraction approaches to remediating sites contaminated with radioactivity. Phytoextraction generates a large volume of waste. There are few facilities that will incinerate radioactive waste. Thus, the radioactive waste removed from a site must be disposed of via subsurface burial. This is extremely costly:

- $\$ 3700 / \mathrm{m}^{3}$ for low level waste,

- $\$ 8800 / \mathrm{m}^{3}$ to $214,000 / \mathrm{m}^{3}$ for mixed waste,

- $\$ 8800 / \mathrm{m}^{3}$ for hazardous waste, and

- $\$ 28,500 / \mathrm{m}^{3}$ for transuranic radioactive (TRU) waste. 


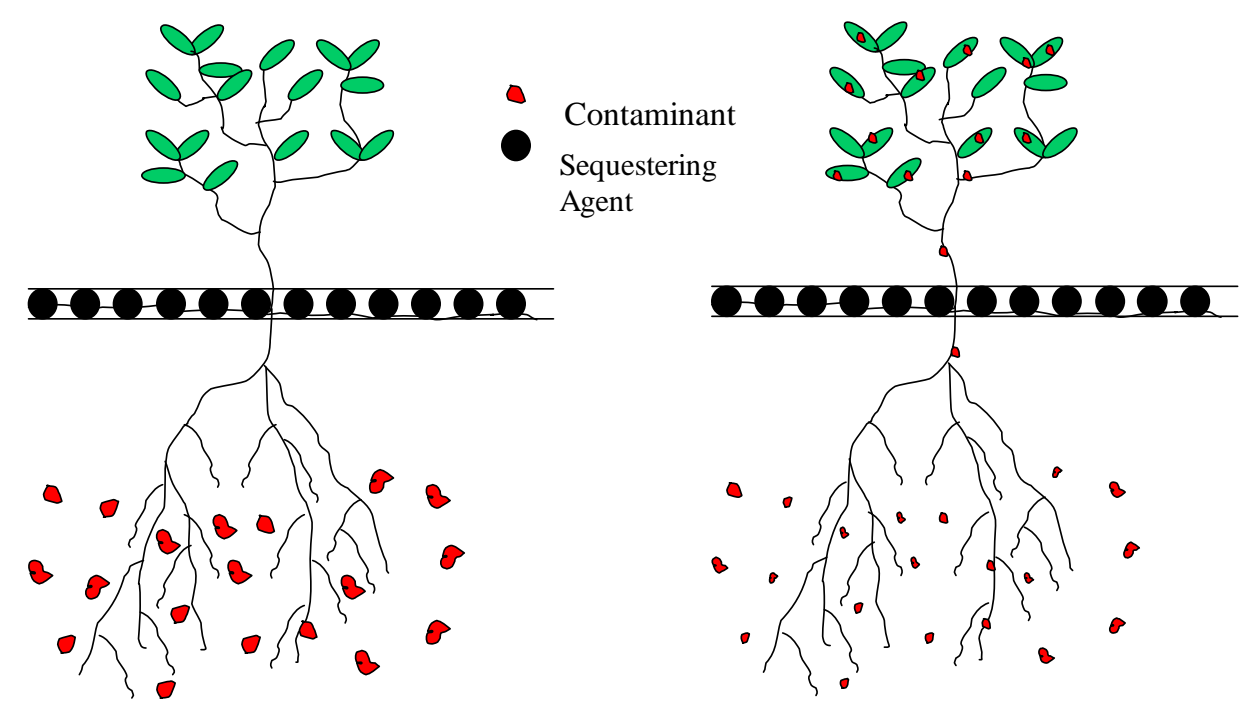

Figure 2. First step in phytoimmobilization, phytoextraction, involves extraction of the sediment contaminant, followed by translocation of the contaminant into the above ground plant parts. 


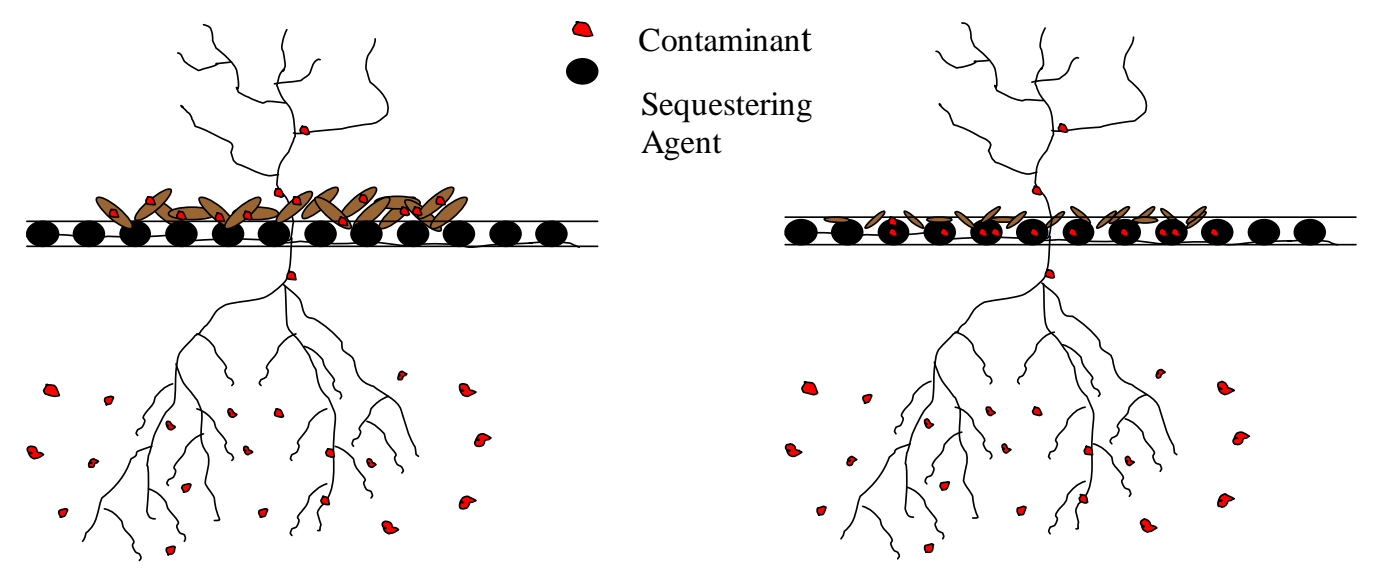

Figure 3. Second step in phytoimmobilization, sequestration, involves immobilizing the contaminants leached from plant litter material within a sequestering agent. 


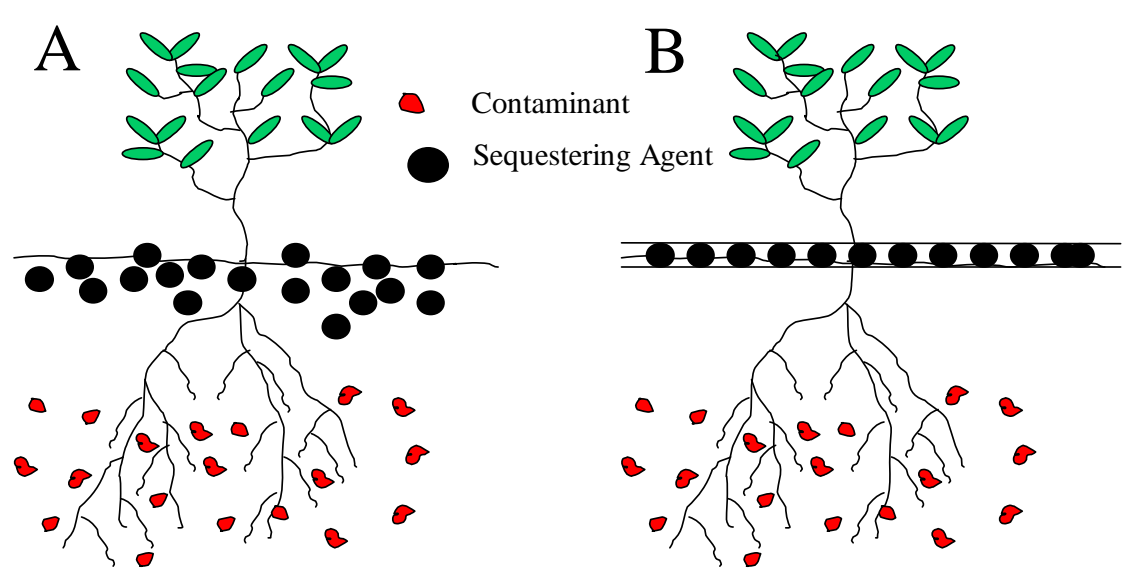

Figure 4. Emplacement of the sequestering agent can be either (A), incorporated into the contaminated sediment surface, or (B) in the geomat configuration.

\subsection{OBJECTIVES}

The objectives of this study were to 1) conduct a proof-of concept of the phytoimmobilization technology, and 2) parameterize a computational design tool that could be used in the future deployment of this technology. Rather than conduct a field demonstration that would be costly and contain an unacceptable amount of scientific uncertainty, it was decided between Savannah River Technology Center and Environmental Restoration Division personnel to conduct a series of small experiments that would independently investigate each of the various processes involved in phytoimmobilization. The important advantage of this approach is that it permitted a large number of controlled experiments to be conducted that could evaluate and quantify the various processes that occur during deployment of the technology.

These experiments were organized to supply information that could be applied to a computational design tool, a linear-kinetic reservoir model. The linear-kinetic reservoir model (Lasaga 1980) uses matrix algebra to evaluate the concentration of a contaminant in various reservoirs as a function of time. The six reservoirs that were considered in the phytoimmobilization project are schematically presented in Figure 5. An example of the output from the linear-kinetic reservoir model is presented in Figure 6. However, the project was terminated prior to completing all the studies needed for supplying input to the model. Instead a simplified mass-balance calculation was conducted using the available data. 
The various experiments that were conducted and how they relate to the conceptual model of the phytoimmobilization process are presented in Figure 7. These studies are:

1. Field Survey of Plant and Soil Contaminant Concentrations: The objective of this study was to determine, as a function of plant species, the contaminant concentrations and the concentration ratio (concentration in plant tissue divided by the concentration in the soil) in herbaceous plants and tree leaves of plants growing in the TNX OD site. Eighteen sets of herbaceous plant, leaf litter, and soil samples were collected from the contaminated and uncontaminated portion of the TNX OD. The samples were then analyzed for their contaminant concentrations.

2. Plant Uptake Experiment: The objective of this greenhouse investigation was to determine the rate at which netted-chain fern (Woodwardia areolata) and Bermuda grass (Cynnodon dactylon) took up contaminants from three different sediments collected from the TNX OD site. The uptake data would then be used in the model.

3. Leaf Leaching Experiment: The objective of this study was to determine the rate at which the contaminants leached from plant material. Plant tissues collected from the TNX OD were placed in a dialysis bag, which in turn was placed in uncontaminated TNX surface water. The rate of contaminant concentrations released from the leaves was monitored over two months.

4. Geomat Efficiency Laboratory Experiment: The objective of this laboratory investigation was to conduct a survey of several potential sequestering agents for their ability to remove contaminants from the aqueous phase.

5. Geomat Efficiency Field Experiment: The objective of this field study was to evaluate the most effective sequestering agents identified during the laboratory study during a one-year period.

6. Geochemistry and Sorption Experiment: The objective of this laboratory investigation was to quantify the relative availability (leachability) of the contaminants within TNX OD soils and to provide Kd values for the model. 


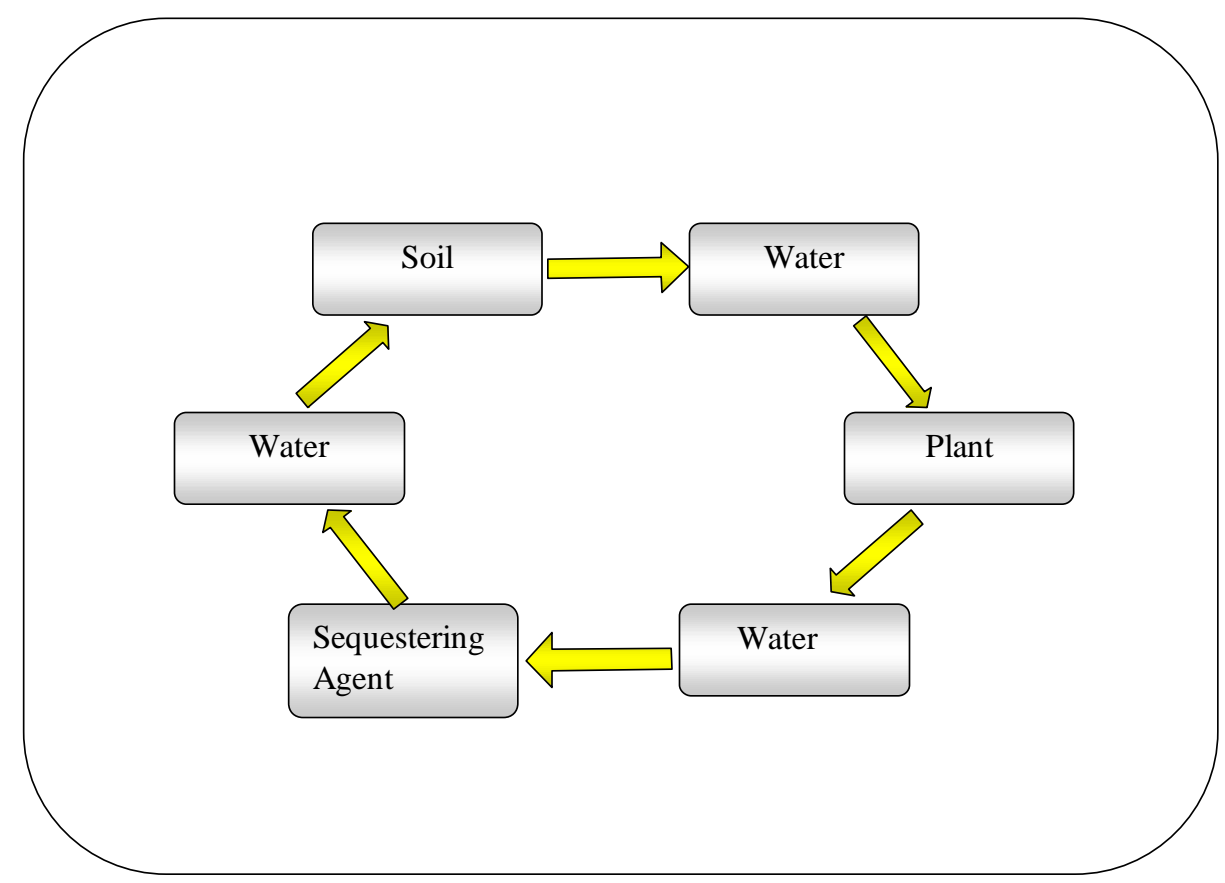

Figure 5. Contaminant reservoirs included in the linear-kinetic reservoir model. 


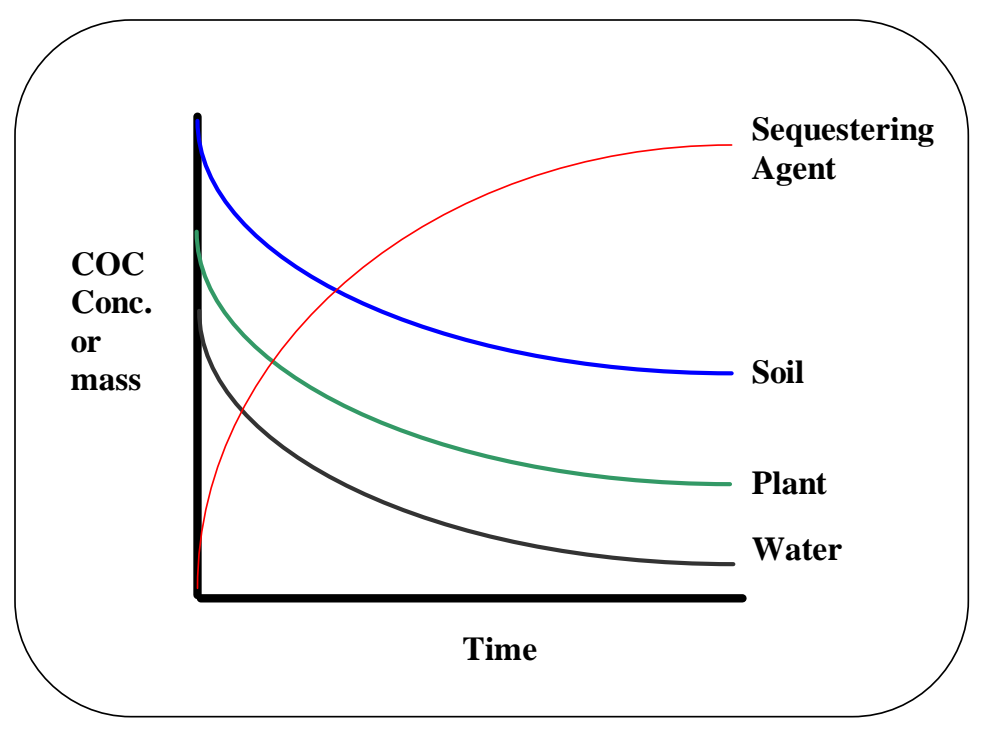

Figure 6. Example of the type of output that the linear-kinetic reservoir model produces (COC stands for constituent of concern). 


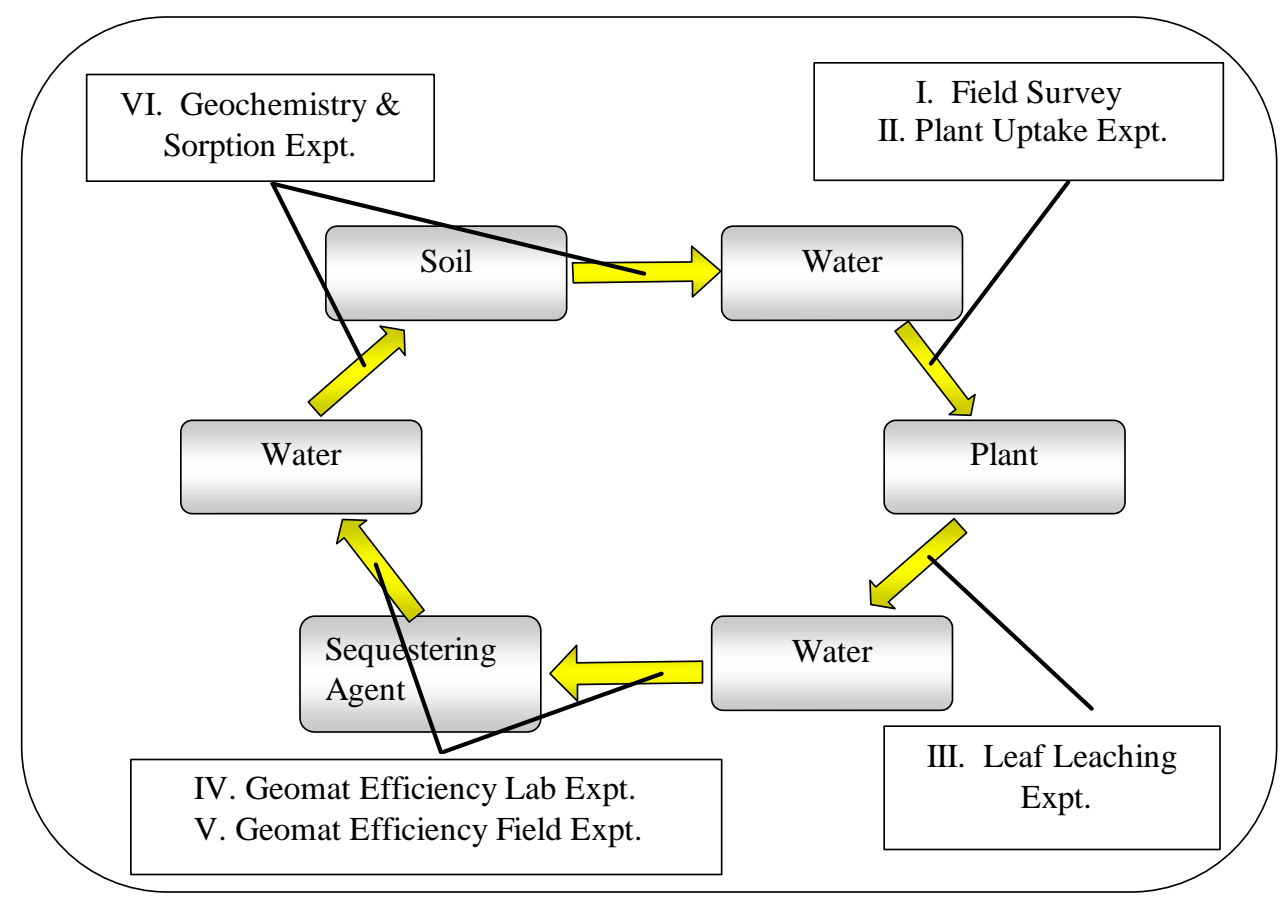

Figure 7. Experiments conducted and their relation to the linear-kinetic reservoir model.

\subsection{SCOPE}

The constituents of concern (COCs) in these studies were $\mathrm{Ac}, \mathrm{Ba}, \mathrm{Co}, \mathrm{Cr}, \mathrm{Hg}, \mathrm{Pb}, \mathrm{Ra}$, Th, and $\mathrm{U}$. Evaluation of the technology was made relevant to the TNX OD operable unit. To reduce analytical cost, it was decided by Savannah River Technology Center and Environmental Restoration Division personnel to restrict analyses to inductively coupled plasma - mass spectrometry (ICP-MS) and cold-vapor fluorescence spectroscopy, avoiding costly radiochemical analyses. Actinium and Ra concentrations were below detection by the ICP-MS. Thus, Eu and Ce, both trivalent cations, were used as analogues for Ac biogeochemical behavior, and $\mathrm{Ba}$, a divalent cation, was used as an analogue for $\mathrm{Ra}$ biogeochemical behavior. Europium, $\mathrm{Ce}$, and Ba were easily detected by the ICP-MS. The cold-vapor fluorescence spectroscopy was used for $\mathrm{Hg}$ analyses. 
This project was terminated early, thus not all of the original objectives were achieved. The project was terminated because simplified mass-balance calculations indicated that the phytoimmobilization technology would not clean up the site of all the radionuclides in a timely manner.

\subsection{STATUS}

The project included 7 tasks: one task for each of the six objectives presented in the Objective Section (Section 2.2) and a modeling task. The status of each task is presented in Table 1. All subtasks were completed except for the following:

- collecting the $2^{\text {nd }}$ year of data from the Plant Uptake Greenhouse Experiment (Task 2),

- analyzing the chemical composition of the leachates recovered from the Leaf Leaching Experiment (Task 3),

- collecting data for the Geomat Efficiency Field Experiment (Task 5), and

- conducting the linear-kinetic reservoir modeling (Task 7).

Since the status report (Kaplan et al. 2000a), the following subtasks were completed:

- Sample chemical analysis of the plant and soil samples collected during the Field Survey of Plant and Soil Contaminant Concentrations Task,

- Completion of the $1^{\text {st }}$ harvest of the Plant Uptake Greenhouse Experiment, and

- Completion of the abbreviated mass-balance model of phytoimmobilization at the TNX OD.

The results from these newly completed experiments have been incorporated into the results presented in the status report (Kaplan et al. 2000a). This report contains roughly twice as much information as the status report. The status report contained 10 figures, this report contains 17 figures; the status report contains 15 tables, this report contains 41 tables; the status report was 40 pages long, this report is greater than 90 pages long. 
WSRC-TR-2001-00032, REV. 0

Table 1. Status and reporting of project tasks.

\begin{tabular}{|c|c|c|c|c|}
\hline No. & Task & Subtask & $\begin{array}{l}\text { Completion } \\
\text { Status }\end{array}$ & First Reported \\
\hline 1 & $\begin{array}{l}\text { Field Survey of Plant and Soil } \\
\text { Contaminant Concentrations }\end{array}$ & $\begin{array}{l}\text { - Collect samples and extract soil and } \\
\text { digest plant material } \\
\text { - Analyze samples }\end{array}$ & $\begin{array}{l}\text { Completed } \\
\text { Completed }\end{array}$ & $\begin{array}{l}\text { Kaplan et al. 2000a } \\
\text { This report, Section 4.2.2 }\end{array}$ \\
\hline 2 & Plant Uptake Greenhouse Expt. & 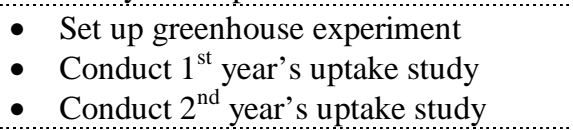 & $\begin{array}{l}\text { Completed } \\
\text { Completed } \\
\text { Incomplete }\end{array}$ & $\begin{array}{l}\text { Kaplan et al. } 2000 \mathrm{a} \\
\text { This report, Section } 4.3\end{array}$ \\
\hline 4 & $\begin{array}{l}\text { Geomat Efficiency Laboratory } \\
\text { Expt. }\end{array}$ & - Conduct Experiment & Completed & Kaplan et al. $2000 \mathrm{a}$ \\
\hline 5 & Geomat Efficiency Field Expt. & $\begin{array}{l}\text { - Set up experiment in field } \\
\text { - Conduct experiment: collect and } \\
\text { chemically characterize plant and } \\
\text { sequestering agents }\end{array}$ & $\begin{array}{l}\text { Completed } \\
\text { Incomplete }\end{array}$ & Kaplan et al. $2000 \mathrm{a}$ \\
\hline 7 & Modeling Phytoimmobilization & $\begin{array}{l}\text { Write and test linear-kinetic reservoir } \\
\text { model } \\
\text { - Run simulations with linear-kinetic } \\
\text { reservoir model } \\
\text { - } \\
\end{array}$ & $\begin{array}{l}\text { Completed } \\
\text { Incomplete } \\
\text { Completed }^{(b)}\end{array}$ & This report, Section 4.7.2 \\
\hline
\end{tabular}




\subsection{MATERIALS AND METHODS}

There were seven tasks in this project: the six experiments depicted in Figure 7 and a modeling task. The Materials and Methods of each of the seven tasks are described below.

\subsection{PLANTS AND SOIL FIELD SURVEY AT THE TNX OD SITE}

The objectives of this study were to determine, as a function of plant species, the contaminant concentrations and the concentration ratios (concentration in plant tissue divided by the concentration in the soil) in herbaceous plants and leaves of trees growing in the TNX OD site. A secondary objective was to determine the annual litter biomass ( $\left.\mathrm{kg} / \mathrm{m}^{2} / \mathrm{yr}\right)$. A detailed description of the QA/QC and the sampling protocol used in this task is presented in the "Sampling and Analyses Plan for the Phytostabilization Study at the TNX Outfall Delta, Lower Discharge Gully and Swamp Operable Unit” (Kaplan 1999).

To accomplish the first objective, herbaceous plant, leaf litter, and soil samples were collected from 18 locations in the TNX OD (Figure 8). Three factors were considered when deciding where to collect samples: 1) soil contaminant concentration, 2) number of soil contaminants present, and 3) soil type. The first two factors were evaluated by consulting with Environmental Restoration Division personnel familiar with the study site and by examining contaminant maps of the study site published in a recent draft report (WSRC 1999). The third factor, soil type, was identified from soil maps (basically, there is a wetland and a non-wetland, or upland, soil type in the TNX OD). Sample sites were located in both soil types and in areas containing the maximum number of contaminants at concentrations that could be readily detected. Additionally, two sample sites were located in uncontaminated areas adjacent to the TNX OD.

A soil, leaf litter and herbaceous plant sample was collected at each sample site during the week of November 11, 1999. The soil was collected by hand auguring down to 0.3-m. This upper portion of the soil profile was selected for sampling because it generally contains the highest contaminant concentrations (WSRC 1999). Leaf litter samples were collected from litter baskets located at the sample site, which are described in more detail below. Gardening shears were used to cut the herbaceous samples $5-\mathrm{cm}$ above ground. The lower $5-\mathrm{cm}$ of the plants were not used because they likely were contaminated by the soil. A dominant herbaceous species at each sample site was sampled. About 200-g of fresh leaf litter and herbaceous plant materials and 500-g of soil were collected.

The soil was totally digested with strong acids to provide a measure of the total concentration of soil contaminants. The soil contaminants were also partially extracted with 0.05 M DTPA to provide a measure of the "plant available" contaminant soil fraction. The DTPA extract procedure was taken from the agricultural literature and is an index of transition metal availability to plants (Lindsay and Norvell 1978). 
A subset of the leaf litter samples was sorted by species, digested, and then analyzed for Eu (an analogue for $\mathrm{Ac}$ ), $\mathrm{Co}, \mathrm{Cr}, \mathrm{Pb}, \mathrm{Ba}$ (an analogue for $\mathrm{Ra}$ ), Th, and $\mathrm{U}$ by ICP-MS, and for $\mathrm{Hg}$ by cold-vapor atomic fluorescence spectroscopy. All the herbaceous samples were digested and then analyzed for contaminant concentrations.

To determine the annual leaf-litter biomass, 46 litter baskets $\left(0.18-\mathrm{m}^{2}\right)$ were placed at the TNX OD site: 40 litter baskets were placed in the contaminated area, and 6 litter baskets were placed in nearby uncontaminated areas (Figure 9). The litter baskets were made from commercially available, plastic laundry baskets. They were suspended $\sim 0.2-\mathrm{m}$ above the ground with four PVC legs attached to the baskets. Of the 46 litter baskets, 17 were placed in the upland soil type and 29 were placed in the wetland soil type. The leaf litter was periodically collected during the fall. The leaves were brought back to the lab, dried, and then weighed. A subset of the leaf litter samples was sorted by species, digested, and then analyzed for contaminant concentrations. 
WSRC-TR-2001-00032, REV. 0

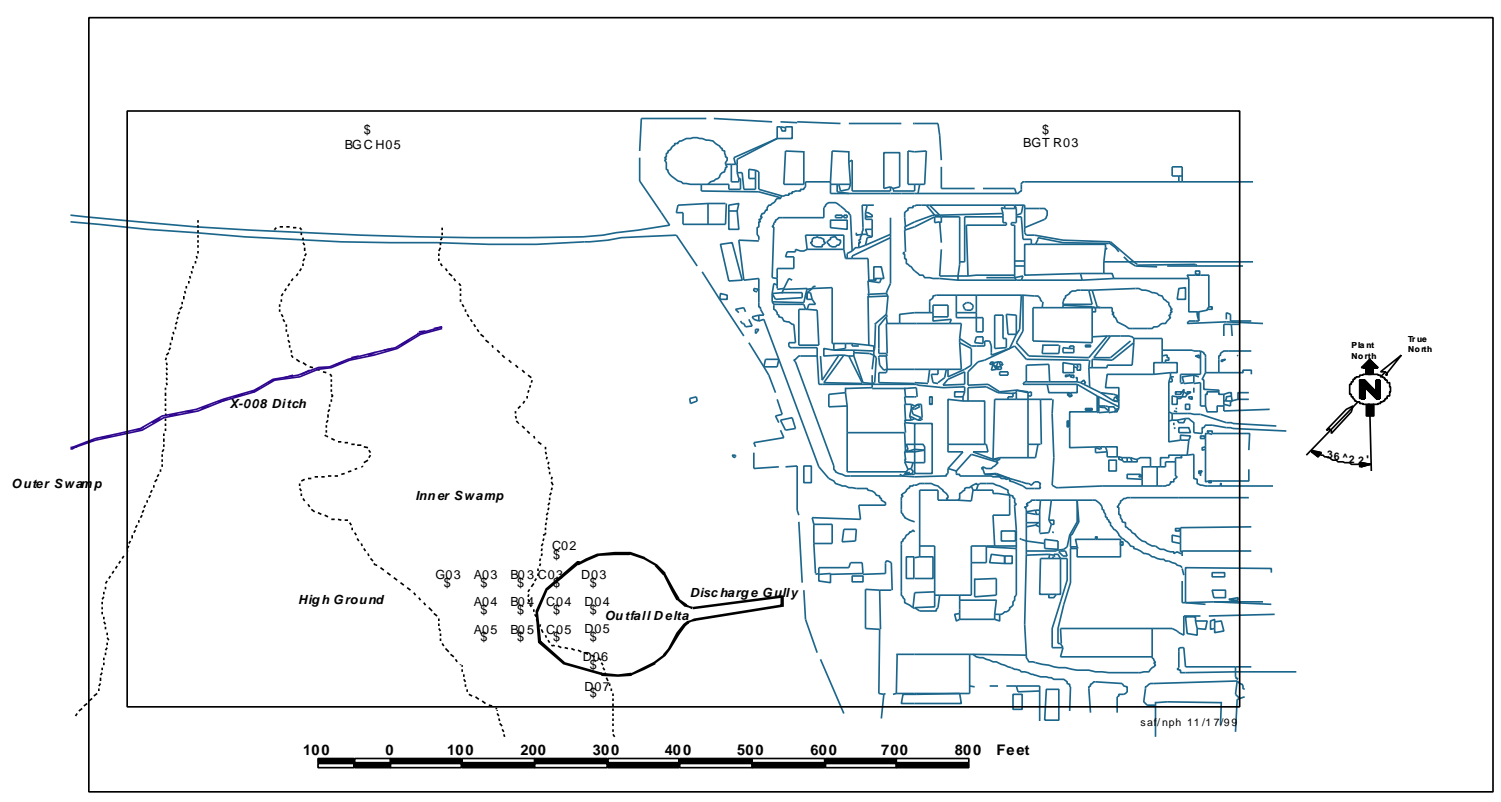

Figure 8. Plant tissue and soil sampling locations at the TNX OD. 
WSRC-TR-2001-00032, REV. 0

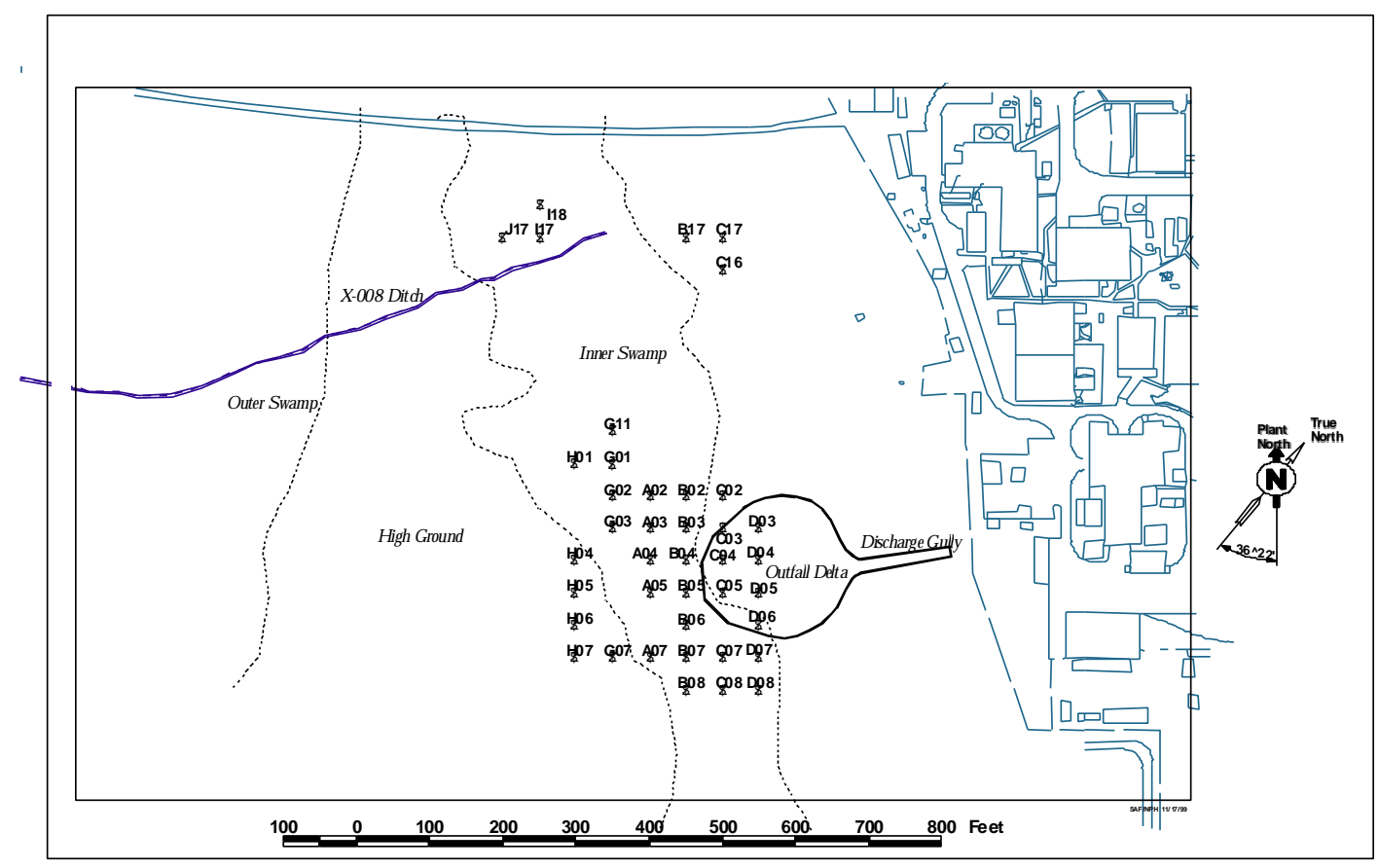

Figure 9. Litter Basket locations at the TNX-OD.

Page 24 


\subsection{PLANT UPTAKE GREENHOUSE EXPERIMENT}

The objective of the greenhouse study was to determine the contaminant concentrations that would accumulate in the aboveground portion of netted-chain ferns (Woodwardia areolata) and Bermuda grass (Cynnodon dactylon) grown in TNX OD contaminated soils. This study was conducted at the Savannah River Ecology Laboratory's greenhouse facility. There was one uncontaminated soil collected from coordinate K-26, and two contaminated soils collected from coordinates B-5 and C-5 (Figure 8). The netted-chain fern was selected because, during a preliminary sampling of herbaceous plants at the study site, it was discovered that this plant species accumulated large concentrations of several contaminants. The Bermuda grass was selected because it is a monocotyledon and would provide a striking contrast to the uptake behavior of the netted-chain fern, a pteridophyte. Additionally, Bermuda grass seed was available.

The experimental factorial design was 3 soil types, 2 plant species, and 4 replicates. For the Bermuda grass, the 2 fertilizer regimes, with and without $25-\mathrm{kg} / \mathrm{ha} 10-10-10$, N-P-K fertilizer were also evaluated for two of the soils (Background and C-5). In addition to these treatments there were 12 control pots without plants: 2 fertilizer regimes x 3 soil types $\mathrm{x} 2$ replicates. Two-kg of soil were added to each pot that grew Bermuda grass and 5-kg soil were added to each pot that grew the netted-chain fern. The pots contained one large hole on the bottom to permit excess water to leave the root zone. Each pot was placed in a larger pot without holes to contain contaminated water. Netted-chain ferns were collected from a noncontaminated portion of the TNX OD and transplanted into the pots on 26 July 2000. The Bermuda grass was seeded directly into the pots on 28 July 2000 . The plants were watered every workday and the water that collected in the outside pot was reintroduced to the soil.

Plant samples were collected 15 September 2000, approximately 8 weeks after initiating the experiment. Soil samples were collected 28 July 2000, the first day of the experiment. Approximately 50-g (wet) of plant material and $20 \mathrm{-g}$ of soil were collected. The plant samples were digested and then the samples were analyzed for contaminant concentrations. The soil samples were subjected to total digestion, to provide a measure of the total contaminant soil concentration, and to DTPA extraction, to provide a measure of plantavailable contaminant concentrations. The study was terminated prior to collecting the second sample, which was planned for this spring.

\subsection{LEAF LEACHING EXPERIMENT}

The objective of this experiment was to determine the rate that contaminants leached from leaves. Netted-chain fern was collected from an uncontaminated and contaminated (coordinate A-5; Figure 9) portion of the study site. Five grams of fern material from each site were placed in dialysis bags and then placed in separate glassware containing 200-mL of uncontaminated surface water collected from near the TNX-OD. These tests were conducted in duplicate. The treatment dialysis bags and solutions were placed on a stir plate. 
5-ml aliquots were periodically collected during a 2-month equilibration period from the aqueous phase. The study was terminated prior to submitting the aqueous samples for chemical analysis.

\subsection{GEOMAT EFFICIENCY LABORATORY EXPERIMENT}

The objective of this laboratory study was to conduct a survey of potential sequestering agent materials that could be used in conjunction with the phytoimmobilization technology at the TNX OD site. The following sequestering agents were tested:

- metallic iron $(\mathrm{Fe})$,

- North Carolina apatite (NCA),

- hydroxylapatite (HA),

- zeolite (clinoptilolite -ZC and phillipsite-ZP),

- Fe oxide waste (Fe rich ${ }^{\mathrm{TM}}$ waste byproduct from an industrial process that generates $\mathrm{TiO}_{2}$ pigment; E.I. Du Pont de Nemours, Wilmington, DE),

- gypsum, and

- pyrite.

To avoid interactions between COCs and to minimize waste handling, the tests were conducted in three separate experiments: a $\mathrm{Cr}$ experiment; a $\mathrm{Hg}$ experiment; and a $\mathrm{Ba}$ (used as an analog for radium), $\mathrm{Co}, \mathrm{Pb}$, and $\mathrm{U}$ experiment. All experiments were conducted in centrifuge tubes and had a contact time of 1-wk. Each treatment had three replicates. Two background solutions were used in these studies: distilled water and rainwater with organic carbon added to it. The latter background solution was intended to approximate leaf leachate, the solution expected to come into contact with the sequestering agent during the deployment of phytoimmobilization. About 200-g (dry weight) of leaf-litter collected from a non-contaminated area of TNX was put in contact with 2-L of rainwater collected from Aiken, SC during April 2000. The leaf-litter suspension was left for about 3-wk at room temperature. The water became opaque from the leaching of organic matter from the leaflitter. Three sets of spike solutions were prepared with the distilled water and the high organic matter leachate solution. For the Cr experiment, the two background solutions were spiked with $1-\mathrm{mg} \mathrm{L}^{-1} \mathrm{Cr}(\mathrm{VI})$. For the $\mathrm{Hg}$ experiment, the two background solutions were spiked with 2-mg L ${ }^{-1} \mathrm{Hg}(\mathrm{II})$. For the $\mathrm{Ba}, \mathrm{Co}, \mathrm{Pb}$, and $\mathrm{U}$ experiment, the background solutions were spiked with $50-\mu \mathrm{g} \mathrm{L}^{-1}$ of each COC.

Approximately $0.3-\mathrm{g}$ of each sequestering agent was shaken with $30-\mathrm{mL}$ of spike solution. After a 1-wk contact time, the aqueous phases were analyzed for $\mathrm{Cr}, \mathrm{Ba}, \mathrm{Co}, \mathrm{Pb}$, and $\mathrm{U}$ by ICP-MS and for Hg by Cold-Vapor Atomic Fluorescence Spectrometer. The partitioning of the metals to the various sequestering agents was quantified by a distribution coefficient, $\mathrm{Kd}$ (concentration of contaminant on the solid phase divided by the concentration of the contaminant in the aqueous phase). 


\subsection{GEOMAT EFFICIENCY FIELD EXPERIMENT}

The objective of this study was to field test some of the better sequestering agents identified during the laboratory trials described above in Section 3.4. Twenty-nine mesocosms were established in coordinate $\mathrm{H}-5$ in the study site (Table 2). The mesocosms were made from 15-cm diameter PVC tubing and were 30-cm high. Within each mesocosm, a geomat was placed on top of a $2-\mathrm{cm}$ layer of sand that was designed to act as a spacer to separate the underlying contaminated soil from the geomat. The geomat was made by cutting $16-\mathrm{cm}$ diameter circles out of a geofabric (AMOCO Style 5412, Atlanta, GA). The edges of two geofabric circles were sewn together, leaving a $3-\mathrm{cm}$ opening. Through this opening, 300-g of sequestering agent was added. The opening was then sewn together. A screen was placed on top of the mesocosm to minimize the amount of leaves falling into the mesocosm, but at the same time permitting rain to enter.

The project was terminated before plant material could be added to the mesocosms. Details of the proposed experimental plan are presented in the status report (Kaplan et al. 2000a).

Table 2. Experimental matrix for the Geomat Efficiency Field Experiment.

\begin{tabular}{llcc}
\hline & Treatment & \# Replicates & Leaf Material \\
\hline 1 & Fe(0) & 3 & Leaf Litter \\
2 & Apatite & 3 & Leaf Litter \\
3 & Clinoptilolite & 3 & Leaf Litter \\
4 & Clinoptilolite/Apatite/Fe(0) & 3 & Leaf Litter \\
5 & Fe(0) & 2 & Fern \\
6 & Apatite & 2 & Fern \\
7 & Clinoptilolite & 2 & Fern \\
8 & Clinoptilolite/Apatite/Fe(0) & 2 & Fern \\
9 & Fe(0) & 3 & None \\
10 & Apatite & 3 & None \\
11 & Clinoptilolite & 3 & None \\
\hline
\end{tabular}

\subsection{GEOCHEMISTRY \& SORPTION EXPERIMENT}

The objective of this study was to determine the relative availability of the various contaminants and to determine distribution coefficients, $\mathrm{Kd}$ values, which could be used in modeling the phytoimmobilization technology. The laboratory portion of this work was completed as part of a previous study (Kaplan et al. 1999). The site-specific field data taken from this report that will be used in our modeling are presented in Section 4.7. 


\subsection{MODELING PHYTOIMMOBILIZATION}

It was originally planned that a linear-kinetic reservoir model would be used to predict the effectiveness of applying the phytoimmobilization technology at the study site. However, an abbreviated mass-balance model was used to provide some preliminary estimates. Although this simplified model lacks technical rigor, it could be used with the existing data and provided an early indication of the technology efficacy. A description of the model, input parameters used in the calculations and the results from the calculations are presented in the Results section, Section 4.7. Insufficient data were available for conducting calculations with the linear-kinetic reservoir model. A brief discussion of the linear-kinetic reservoir model and the available input values is provided in the Results section, Section 4.7.2. A more detailed description of the model is provided in the status report (Kaplan et al. 2000a).

\subsection{RESULTS AND DISCUSSION}

\subsection{PLANT AND SOIL FIELD SURVEY AT THE TNX OD SITE}

\subsubsection{Annual Biomass Estimates}

Table 3 gives the mass of leaf litter collected from 40 sampling baskets located in the contaminated area and 6 sampling baskets located in the uncontaminated area of the study site. Unfortunately, the project was not initiated until October 1, 1999 and the sampling baskets were placed in the field after the deciduous leaves had started to fall. ${ }^{1}$ Consequently, these data underestimate the true amount of leaves that fall annually. Due to radiological safety concerns, we were not permitted to collect the leaves beneath the baskets that had already fallen in the contaminated area. However, we were able to collect and weigh the leaves beneath the collection baskets located in the uncontaminated area. The annual leaflitter biomass at the site was estimated based on the leaf biomass ratio in and beneath the sampling baskets in the uncontaminated area (Table 4). Based on these 6 uncontaminated samples, the annual leaf-litter biomass is:

- $7389 \pm 833 \mathrm{~kg} / \mathrm{ha} / \mathrm{yr}$ for the wetland soils, and

- $5556 \pm 1056 \mathrm{~kg} / \mathrm{ha} / \mathrm{yr}$ for the upland soils.

Only $24 \%$ and $33 \%$ of the total leaf litter that fell during the fall of 1999 was collected in the baskets located in the wetlands and uplands, respectively.

\footnotetext{
${ }^{1}$ It was not possible to collect leaf litter data in the fall of 2000 because the project was terminated before all the autumn leaves had fallen.
} 
Table 3. Leaf litter mass collected on March 15, 2000 from sampling baskets placed in 40 locations in the contaminated area and 6 locations in the uncontaminated area.

\begin{tabular}{|c|c|c|c|}
\hline Site Coordinate & Contamination/Control & Soil Type & Leaf Litter Mass (g) \\
\hline A-2 & Contaminated & Wetland & 61.63 \\
\hline A-3 & Contaminated & Wetland & 51.2 \\
\hline A-4 & Contaminated & Wetland & 35.65 \\
\hline A-5 & Contaminated & Wetland & 33.18 \\
\hline A-7 & Contaminated & Wetland & 58.45 \\
\hline B-2 & Contaminated & Wetland & 89.25 \\
\hline B-3 & Contaminated & Wetland & 55.93 \\
\hline B-4 & Contaminated & Wetland & 46.67 \\
\hline B-5 & Contaminated & Wetland & 22.97 \\
\hline B-6 & Contaminated & Wetland & 51.29 \\
\hline B-7 & Contaminated & Wetland & 50.82 \\
\hline B-8 & Contaminated & Wetland & 54.83 \\
\hline $\mathrm{C}-2$ & Contaminated & Upland & 73.32 \\
\hline $\mathrm{C}-3$ & Contaminated & Upland & 52.6 \\
\hline $\mathrm{C}-4$ & Contaminated & Upland & 50 \\
\hline $\mathrm{C}-5$ & Contaminated & Upland & 39.14 \\
\hline $\mathrm{C}-7$ & Contaminated & Wetland & 51.38 \\
\hline $\mathrm{C}-8$ & Contaminated & Wetland & 51.3 \\
\hline D-3 & Contaminated & Upland & 44.2 \\
\hline D-4 & Contaminated & Upland & 47.8 \\
\hline D-5 & Contaminated & Upland & 39.1 \\
\hline D-6 & Contaminated & Wetland & 32.1 \\
\hline D-7 & Contaminated & Wetland & 38.9 \\
\hline D-8 & Contaminated & Wetland & 39.32 \\
\hline G-1 & Contaminated & Wetland & 84.1 \\
\hline G-11 & Contaminated & Wetland & 79.32 \\
\hline G-3 & Contaminated & Wetland & 61.65 \\
\hline G-7 & Contaminated & Wetland & 52.49 \\
\hline $\mathrm{H}-1$ & Contaminated & Wetland & 57.33 \\
\hline $\mathrm{H}-2$ & Contaminated & Wetland & 92.77 \\
\hline H-4 & Contaminated & Upland & 53.85 \\
\hline H-5 & Contaminated & Upland & 54 \\
\hline H-6 & Contaminated & Upland & 81.8 \\
\hline $\mathrm{H}-7$ & Contaminated & Upland & 62.64 \\
\hline C-18 & Contaminated & Upland & 53.89 \\
\hline C-17 & Contaminated & Upland & 76.46 \\
\hline D-17 & Contaminated & Upland & 44.84 \\
\hline $\mathrm{I}-17$ & Contaminated & Wetland & 39.86 \\
\hline $\mathrm{I}-18$ & Contaminated & Wetland & 60.19 \\
\hline $\mathrm{J}-17$ & Contaminated & Wetland & 78.5 \\
\hline TNXOFD-BG1 & Control & Wetland & 50.78 \\
\hline BGCH-7 & Control & Wetland & 21.32 \\
\hline K-26 & Control & Wetland & 24 \\
\hline BGTRO3 & Control & Upland & 24.3 \\
\hline West of $44(50 \mathrm{~m})$ & Control & Upland & 27.4 \\
\hline East of $44(50 \mathrm{~m})$ & Control & Upland & 46.82 \\
\hline
\end{tabular}


Table 4. Annual leaf-litter biomass estimates for leaves at the TNX OD.

\begin{tabular}{|c|c|c|c|c|c|c|c|c|}
\hline $\begin{array}{l}\text { Soil } \\
\text { Type }\end{array}$ & Sample ID & $\begin{array}{l}\text { Leaf Litter } \\
\text { in Basket }{ }^{\text {(a) }} \\
\left(\mathrm{g} / 0.18 \mathrm{~m}^{2}\right)\end{array}$ & $\begin{array}{l}\text { Leaf Litter } \\
\text { Beneath }^{(\mathrm{a})} \\
\text { Basket }^{2} \\
\left(\mathrm{~g} / 0.18 \mathrm{~m}^{2}\right)\end{array}$ & $\begin{array}{l}\text { Total Leaf } \\
\text { Litter } \\
\left(\mathrm{g} / 0.18 \mathrm{~m}^{2}\right)\end{array}$ & $\begin{array}{c}\text { Mass }^{(b)} \\
\left(\mathrm{g} / 0.18 \mathrm{~m}^{2}\right)\end{array}$ & $\begin{array}{c}\text { Mass }^{(\mathrm{b})} \\
(\mathrm{kg} / \mathrm{ha} / \mathrm{yr})\end{array}$ & $\begin{array}{c}\% \text { in } \\
\text { Basket }\end{array}$ & $\begin{array}{c}\text { Ave. \% } \\
\text { in } \\
\text { Basket }\end{array}$ \\
\hline \multirow[t]{3}{*}{ Wetland } & TNXOFD-BG1 & 50.78 & 97.0 & 147.78 & $133 \pm 15$ & $7389 \pm 833$ & 34 & $24 \pm 10$ \\
\hline & BGCH-7 & 21.32 & 113.04 & 134.36 & & & 16 & \\
\hline & $\mathrm{K}-26$ & 24 & 94.2 & 118.2 & & & 20 & \\
\hline \multirow[t]{3}{*}{ Upland } & BGTRO3 & 24.3 & 54.3 & 78.6 & $100 \pm 19$ & $5556 \pm 1056$ & 31 & $33 \pm 8$ \\
\hline & West of $44(50 \mathrm{~m})$ & 27.4 & 80.95 & 108.35 & & & 25 & \\
\hline & East of $44(50 \mathrm{~m})$ & 46.82 & 66.26 & 113.08 & & & 41 & \\
\hline
\end{tabular}

(a) Leaf litter was collected between November 9, 1999 and March 15, 2000. By November 9, 1999, leaves had already started falling. The recently fallen leaves beneath the leaf litter baskets were collected and weighed and their mass is reported in "Leaf Litter Beneath Basket." By March 15, 2000, essentially all of the deciduous leaves had fallen. The leaf litter baskets had an area of $0.5-\mathrm{m}^{2}$.

(b) Average \pm standard deviation.

\subsubsection{Plant Species Abundance}

The material collected in 21 leaf litter baskets was separated by species. The percent of the mass of each species is presented in Table 5 and Table 6. A list of the scientific names of many of the plant species referred to in this report is presented in Appendix A. A summary of the relative abundance of the dominant species is present in Table 7. Water oak, tupelo, baldcypress, and loblolly pine account for $43 \%$ of the total leaf litter mass. 
WSRC-TR-2001-00032, REV. 0

Table 5. Species-composition of leaf litter (wt-\%) (Table continues in Table 6).

\begin{tabular}{|c|c|c|c|c|c|c|c|c|c|c|c|}
\hline $\begin{array}{l}\text { Location Map } \\
\text { Node }\end{array}$ & Soil Type & $\begin{array}{c}\text { Bald- } \\
\text { cypress }^{(a)}\end{array}$ & Willow & Pine & Sycamore & Red Maple & Unknown & Water Oak & Oak & Tupelo & $\begin{array}{l}\text { Tupelo } \\
\text { Seeds }\end{array}$ \\
\hline A-2 & Wetland & $35^{(\mathrm{b})}$ & (c) & 11 & & 4 & & 1 & 2 & 44 & \\
\hline A-5 & Wetland & 11 & & 3 & & 55 & & 21 & & 5 & \\
\hline A-7 & Wetland & 25 & & 9 & & 4 & & 7 & & 35 & 17 \\
\hline B-2 & Wetland & 41 & & 15 & & 7 & & 2 & & 28 & \\
\hline B-3 & Wetland & 19 & & & & 15 & & 2 & & 55 & \\
\hline B-4 & Wetland & 28 & & & & 3 & & 1 & & 4 & \\
\hline B-5 & Wetland & 44 & & & & 56 & & & & & \\
\hline $\mathrm{C}-3$ & Upland & 17 & & 8 & 41 & 7 & & & & 6 & \\
\hline C-4 & Upland & 5 & 15 & 23 & 31 & 19 & 2 & 4 & & & \\
\hline C-5 & Upland & 3 & & 36 & & 52 & 5 & & 4 & & \\
\hline D-3 & Upland & 2 & & 20 & 21 & & & 10 & & & \\
\hline D-6 & Wetland & & & & 26 & & & 11 & 29 & 5 & \\
\hline D-7 & Wetland & & & & & & & & & & \\
\hline D-8 & Wetland & 10 & & 26 & & & & 15 & & 47 & \\
\hline G-2 & Wetland & & & & & & & & & & \\
\hline G-3 & Wetland & 37 & & & & & & 9 & & 22 & 12 \\
\hline G-7 & Wetland & & & 36 & & & & 36 & & & \\
\hline TNXOFD-BG1 & Wetland & 5 & & 60 & & & & 16 & & & \\
\hline BGCH-7 & Wetland & & & 54 & & & & 46 & & & \\
\hline K-26 & Wetland & & & 11 & & 9 & & 76 & & & \\
\hline BGTRO3 & Upland & & & 6 & & & 9 & 75 & & & \\
\hline West of $44(50 \mathrm{~m})$ & Upland & & & 7 & & & & 8 & & & \\
\hline East of $44(50 \mathrm{~m})$ & Upland & & & 6 & & & & 75 & & 19 & \\
\hline
\end{tabular}

(a) The scientific names for many of these plant species are presented in Table 7.

(b) Total leaf litter mass is presented in Table 3.

(c) Empty cells within the table indicate $0 \mathrm{wt}-\%$ of species was present in the sample. 
WSRC-TR-2001-00032, REV. 0

Table 6. Specie-composition of leaf litter (\%-g species/100-g total leaf litter) (Table continues in Table 5).

\begin{tabular}{|c|c|c|c|c|c|c|c|c|c|}
\hline $\begin{array}{l}\text { Map Node } \\
\text { Location }\end{array}$ & Soil Type & Sweetgum $^{(a)}$ & Iron Wood & Vitis spp. & Ilex opaca & Sticks & Beech & Hickory & Beauty Berry \\
\hline A-2 & Wetland & (b) & & & & 2 & & & 1 \\
\hline A-5 & Wetland & $4^{(\mathrm{c})}$ & & & & & & & \\
\hline A-7 & Wetland & 3 & 1 & & & & & & \\
\hline B-2 & Wetland & & & & & 7 & & & \\
\hline B-3 & Wetland & 2 & & & & 7 & & & \\
\hline B-4 & Wetland & 45 & & 6 & & 12 & & & \\
\hline B-5 & Wetland & & & & & & & & \\
\hline $\mathrm{C}-3$ & Upland & 12 & & & & 9 & & & \\
\hline $\mathrm{C}-4$ & Upland & & & & & & & & \\
\hline$C-5$ & Upland & & & & & & & & \\
\hline D-3 & Upland & 26 & 2 & 14 & 5 & & & & \\
\hline D-6 & Wetland & 29 & & & & & & & \\
\hline D-7 & Wetland & & & & & & & & \\
\hline D-8 & Wetland & & 2 & & & & & & \\
\hline G-2 & Wetland & & & & & & & & \\
\hline G-3 & Wetland & & & & & 20 & & & \\
\hline G-7 & Wetland & 10 & 9 & & 3 & & & 6 & \\
\hline TNXOFD-BG1 & Wetland & & & & 6 & 11 & 3 & & \\
\hline BGCH-7 & Wetland & & & & & & & & \\
\hline K-26 & Wetland & & 4 & & & & & & \\
\hline BGTRO3 & Upland & & & & & & 4 & 6 & \\
\hline West of $44(50 \mathrm{~m})$ & Upland & 30 & & & & & 55 & & \\
\hline East of $44(50 \mathrm{~m})$ & Upland & & 1 & & & & & & \\
\hline
\end{tabular}


Table 7. Mass of leaves of plant species collected from 21-leaf litter baskets located in the contaminated portion of the TNX OD.

\begin{tabular}{llcc}
\hline Common Name & Scientific Name & Mass (kg/ha) & \% Mass \\
\hline Water Oak & Quercus nigra & 98 & 11 \\
Tupelo & Nyssa sylvatica & 97 & 11 \\
Baldcypress & Taxodium distichum & 96 & 11 \\
Loblolly Pine & Pinus taeda & 89 & 10 \\
Red Maple & Acer rubrum & 52 & 6 \\
Sweetgum & Liquidambar styraciflua & 48 & 5 \\
American Sycamore & Platanus occidentalis & 29 & 3 \\
Other & & 381 & 43 \\
Total biomass & & 890 & 100
\end{tabular}

(a) Leaf litter was collected between November 9, 1999 and March 15, 2000. By November 9,1999 , leaves had already started falling. Thus, these values do not represent a total leaf litter biomass. The leaf litter baskets had an area of $0.18-\mathrm{m}^{2}$.

\subsection{FIELD SURVEY OF PLANT AND SOIL CONTAMINANT CONCENTRATIONS}

The objective of this study was to conduct a survey of indigenous plants for their ability to take-up soil contaminants. Originally, it was intended that more in-depth studies of high uptake plants would follow this survey to provide confirmation and greater understanding of the processes responsible for the greater contaminant uptake by the plant. Sixteen sets of soil, herbaceous, and leaf litter samples were collected for this survey. It was important to collect soil samples along with the plant samples because low concentrations in the plant tissue could be attributed to either low soil contaminant concentrations or low plant uptake rates. The total COC concentrations were measured in the soil samples by total digestion. Additionally, the "plant available" COC concentration was extracted from the soils using the DTPA extractant (Lindsay and Norvell 1978). This extractant is commonly used in agriculture to provide a measure of whether trace nutrient fertilizers need to be added to soils to improve plant health (Mengel and Kirkby 1978). For phytoimmobilization, it was anticipated that plants would not be able to extract all the contaminants in the soil, only some "plant available" fraction. 


\subsubsection{Soil Properties at the TNX OD}

Selected soil properties of an uncontaminated soil collected from coordinate BGCH05 and a contaminated soil collected from coordinate A-5 are presented in Table 8. Both soils are acidic, contain moderate levels of organic matter and have a sandy texture. The cation exchange capacity (CEC) values are typical of this area. Also, reported in Table 8 are anion exchange capacity (AEC) values. This parameter is like CEC except it is for anions, and it has been shown to increase substantially in SRS soils under increasingly acidic conditions (Kaplan and Serkiz 1999). The AEC values of these soils are relatively high when compared to levels measured in other parts of the country, thus these soils would be expected to retain anions to a greater extent than other soils. Additional soil characterization and adsorption and desorption properties of the TNX OD soil are reported by Kaplan and Serkiz (1999).

Contaminant concentrations in a soil collected from one of the most contaminated regions of the site, coordinate A-5, and a soil in an uncontaminated portion of the site are presented in Table 9. Concentrations of $\mathrm{Ag}, \mathrm{Cr}, \mathrm{Co}, \mathrm{Cu}, \mathrm{Hg}, \mathrm{Pb}, \mathrm{Th}$, and $\mathrm{U}-238$ are appreciably greater in the A-5 soil than in the background soil. For U-238, there is a four order-of-magnitude difference between the concentrations in these two soils. We are not interested in the concentration of $\mathrm{Ba}$ and $\mathrm{Ce}$ per se, but are interested in these elements only insofar as they can be used as analogues for $\mathrm{Ra}$ and Ac, respectively. Additional discussion of the total soil and available soil COC concentration data are presented in Section 4.2.2. 
WSRC-TR-2001-00032, REV. 0

Table 8. Soil characterization of an uncontaminated background soil collected from coordinate BGCH05 and a contaminated soil collected from coordinate A-5.

\begin{tabular}{|c|c|c|c|c|c|c|c|c|c|}
\hline Soil & $>2-\mathrm{mm}$ & Sand & Silt & Clay & $\mathrm{pH}$ & Organic $\mathrm{C}$ & $\mathrm{CEC}$ & $\mathrm{AEC}$ & Fe-oxides ${ }^{(a)}$ \\
\hline & $(\%, \mathrm{wt})$ & $(\%, \mathrm{wt})$ & $(\%, w t)$ & $(\%, \mathrm{wt})$ & & $(\mathrm{mg} / \mathrm{kg})$ & $\left(\mathrm{cmol}_{(+)} / \mathrm{kg}\right)$ & $\left(\mathrm{cmol}_{-(-)} / \mathrm{kg}\right)$ & $(\%, \mathrm{wt})$ \\
\hline Uncont. Background & $0.8 \pm 1.0^{(\mathrm{b})}$ & $79.4 \pm 2.1$ & $13.6 \pm 0.3$ & $6.3 \pm 0.8$ & $4.16 \pm 0.01$ & 1395 & $4.75 \pm 0.08$ & $1.56 \pm 0.17$ & 0.01 \\
\hline Contaminated A-5 & $21.2 \pm 6.3$ & $48.8 \pm 6.8$ & $23.6 \pm 1.6$ & $6.4 \pm 1.1$ & $4.00 \pm 0.08$ & 1493 & $8.96 \pm 0.09$ & $2.43 \pm 0.05$ & 0.08 \\
\hline
\end{tabular}

Table 9. Elemental Composition ( $\mu \mathrm{g} / \mathrm{g})$ of an uncontaminated background soil collected from coordinate BGCH05 and a contaminated soil collected from coordinate A-5.

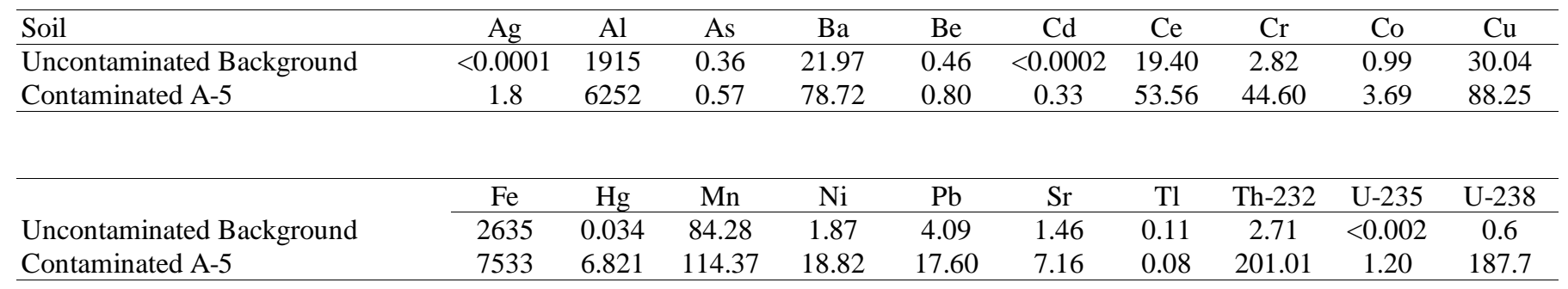




\subsubsection{Contaminant Uptake by Plants Growing in the TNX OD}

As part of a preliminary study, five plants and unsorted tree leaf litter collected from coordinate A-5 were analyzed for targeted contaminant concentrations (Table 10). In addition to reporting contaminant concentrations in the plants, the data were normalized for differences in soil contaminant concentrations by calculating total concentration ratios (CR-T $=\mathrm{mg} / \mathrm{kg}$ dry plant $/$ total $\mathrm{mg} / \mathrm{kg}$ dry soil). It is important to normalize the plant contaminant concentrations in this manner to provide insight as to the cause for low plant contaminant concentrations. Low plant contaminant concentrations could be the result of low soil contaminant concentrations, the contaminant existing in a non-biologically available form, or the plant can avoid the soil contaminant. By expressing the plant uptake data as concentration ratios, it is possible to rule out the first cause, that is, that soil contaminant concentrations were low.

One herbaceous plant, the netted-chain fern (Woodwardia areolata), had relatively large total concentration ratios, especially for $\mathrm{U}, \mathrm{Th}$, and $\mathrm{Hg}$. Also important is that the tree leaf litter contained appreciable concentrations of the targeted contaminants. This is notable because the biomass of the leaf litter is large in this area, and will always account for a majority of the annual litter biomass, even if a monoculture of an herbaceous hyperaccumulater was to be introduced to the site for remediation purposes. The leaf litter had high concentration of Co $(17 \mathrm{mg} / \mathrm{kg})$ and also a high total concentration ratio (4.59). The exceptionally high Co concentration and total concentration ratio in the leaf litter needs confirmation.

Table 10. Elemental composition and total concentration ratio (plant concentration/total soil concentration) of plants collected from coordinate A-5 within the TNX OD on November 11, 1999.

\begin{tabular}{|c|c|c|c|c|c|c|c|c|c|c|c|c|}
\hline \multirow{2}{*}{$\begin{array}{l}\text { Plant/Tree } \\
\text { species }\end{array}$} & \multicolumn{2}{|c|}{$\mathrm{Co}$} & \multicolumn{2}{|c|}{$\mathrm{Cr}$} & \multicolumn{2}{|c|}{$\mathrm{Hg}$} & \multicolumn{2}{|c|}{$\mathrm{Pb}$} & \multicolumn{2}{|c|}{ U-238 } & \multicolumn{2}{|c|}{ Th-232 } \\
\hline & $\begin{array}{c}\mathrm{mg} / \\
\mathrm{kg}\end{array}$ & $\begin{array}{c}\text { CR- } \\
\mathrm{T}\end{array}$ & $\begin{array}{c}\mathrm{mg} / \\
\mathrm{kg}\end{array}$ & $\begin{array}{c}\text { CR- } \\
\mathrm{T}\end{array}$ & $\begin{array}{c}\mathrm{mg} / \\
\mathrm{kg}\end{array}$ & $\begin{array}{c}\text { CR- } \\
\mathrm{T} \\
\end{array}$ & $\begin{array}{c}\mathrm{mg} / \\
\mathrm{kg}\end{array}$ & $\begin{array}{c}\text { CR- } \\
\mathrm{T} \\
\end{array}$ & $\begin{array}{c}\mathrm{mg} / \\
\mathrm{kg}\end{array}$ & CR-T & $\begin{array}{r}\mathrm{mg} / \\
\mathrm{kg}\end{array}$ & CR-T \\
\hline $\begin{array}{l}\text { Netted-chain } \\
\text { Fern }^{(a)}\end{array}$ & 2.4 & 0.65 & 4.7 & 0.11 & 0.8 & 0.12 & 0.7 & 0.17 & 20.7 & 0.11 & 21.5 & 0.107 \\
\hline Switchcane & 0.8 & 0.10 & 1.7 & 0.04 & BDL & --- & 0.6 & 0.15 & 0.6 & 0.003 & 0.8 & 0.004 \\
\hline Red maple & 0.3 & 0.08 & 1.0 & 0.02 & 0.1 & 0.01 & 0.3 & 0.07 & 0.3 & 0.002 & 0.3 & 0.002 \\
\hline Bald-cypress & 0.4 & 0.11 & 0.8 & 0.02 & 0.0 & 0.00 & 0.2 & 0.05 & 0.2 & 0.001 & 0.3 & 0.002 \\
\hline Sweetgum & 0.5 & 0.14 & 1.0 & 0.02 & 0.1 & 0.01 & 0.2 & 0.05 & 4.0 & 0.021 & 0.3 & 0.002 \\
\hline Leaf-litter ${ }^{(b)}$ & 17.0 & 4.59 & 1.1 & 0.02 & BDL & --- & 0.3 & 0.07 & 2.9 & 0.015 & 0.3 & 0.002 \\
\hline
\end{tabular}

(a) Scientific names for plants are presented in Appendix A.

(b) This was an assorted subsample taken directly from the leaf-litter collection baskets. The other tree leaf samples reported in this table were from another subsample that was sorted by tree specie.

(c) B.D.L. = below detection limit, which is $\sim 0.01 \mathrm{mg} / \mathrm{L} \mathrm{Hg}$. 
The remainder of this section will present the data from the full field survey, as opposed to the preliminary data presented above. Correlation coefficients were calculated for the total concentration ratios (CR-T; plant concentration/total soil concentration) and the available concentration ratios (CR-A; plant concentration/available soil concentration) (Table 11). These correlation coefficients include the data from several plant species and different locations at the TNX OD site. The total soil concentrations were appreciably better correlated with plant uptake, as measured by the concentration ratio, than the available soil concentrations. This finding is surprising in light of the fact that there have been several studies conducted in agricultural environments showing the converse to be true (Adriano 1986). However, this trend is true for all nine COCs evaluated. Furthermore, the correlation coefficients for all but one COC, uranium, were significant at the 1- or 5-\% level of probability. Henceforth, our discussion of concentration ratios will focus on the total concentration ratios and total soil concentration data. The available concentration ratio and soil data are included in Table 35 in Appendix A.

Table 11. Correlation coefficients ( $r$ ) between concentration ratios and soil concentrations.

\begin{tabular}{ccc}
\hline Constituent of Concern & Soil-T vs. CR-T & \\
\hline $\mathrm{Ba}(\mathrm{an}$ analog for $\mathrm{Ra})$ & $-0.52^{*(\mathrm{~b})}$ & Soil-A vs. CR-A $^{(\mathrm{a})}$ \\
$\mathrm{Ce}($ an analog for Ac) & $-0.70^{* *}$ & -0.45 \\
$\mathrm{Co}$ & $-0.49^{*}$ & -0.45 \\
$\mathrm{Cr}$ & $-0.74^{* *}$ & -0.10 \\
$\mathrm{Fe}$ & $-0.78^{* *}$ & $-0.55^{*}$ \\
$\mathrm{Hg}$ & $-0.78^{* *}$ & $-0.53^{*}$ \\
$\mathrm{Mn}$ & $-0.59^{* *}$ & $\mathrm{NA}$ \\
$\mathrm{Pb}$ & $-0.76^{* *}$ & $-0.50^{*}$ \\
$\mathrm{U}$ & -0.42 & $-0.48^{*}$ \\
\hline
\end{tabular}

(a) Soil- $\mathrm{T}=$ total soil concentration, $\mathrm{CR}-\mathrm{T}=$ plant concentration/total soil concentration, Soil-A = available soil concentration, $\mathrm{CR}-\mathrm{A}=$ plant concentration/available soil concentration.

(b) * identifies a significant correlation at the $\leq 0.05$ level of probability for 17 observations (critical $r$ is \pm 0.46 ).

$* *$ identifies a significant correlation at the $\leq 0.01$ level of probability for 17

observations (critical $r$ is \pm 0.58 ). 
COC concentrations in the leaf litter collected in the sampling baskets are organized in Table 12 by plant species. The primary advantage of organizing the data in this manner is that it is easy to compare COC concentrations in plants grown in contaminated and uncontaminated portions of the study site. Many of the plants were able to take up more $\mathrm{Cr}$ and $\mathrm{Co}$, and especially $U$ and $T h$ from contaminated soils than from uncontaminated soils. Especially high Th uptake was observed in tupelo, sweetgum and water oak, and of U uptake by tupelo, sweetgum, and red maple. Oddly, several plants were able to take up more $\mathrm{Sr}$ in the uncontaminated soils than in the contaminated soils. The cause for this is not known.

Mn and Fe biogeochemistry was included in this study because the uptake of these two essential plant nutrients has been shown to have a profound impact on contaminant uptake (Adriano 1986, Mengel and Kirkby 1978). These elements influence plant health because they are essential nutrients. These elements influence COC soil retention because they can form strongly sorbing solid oxyhydroxides. Statistical analysis found a significant $(\mathrm{P} \leq 0.01)$ correlation between $\mathrm{Fe}$ total concentration ratios and $\mathrm{Ba}, \mathrm{Cr}, \mathrm{Pb}$, and $\mathrm{U}$ total concentration ratios and between $\mathrm{Mn}$ total concentration ratios and $\mathrm{Ce}, \mathrm{Cr}, \mathrm{Pb}$, and $\mathrm{U}$ total concentration ratios (Table 13). Unfortunately, no cause and effect can be invoked based on this data and therefore it is not possible to elucidate any mechanism(s) to explain this data. Suffice it to say, a strong correlation exists between the uptake of Fe and Mn and a number of the COC.

Concentration ratio data are presented in Table 14 from samples collected in the contaminated portion of the study site. It is not possible to conduct statistical comparisons between plant species and between elements because neither site nor plant type were held constant (e.g., tupelo CR-T data was collected from sites A-5 and B-3, whereas red maple was collected from C-5 and B-3). However, some rankings can be made based on this data. A ranking of the COCs and $\mathrm{Mn}$ and $\mathrm{Fe}$ by their total concentration ratios is:

$$
(\mathrm{Mn} \approx \mathrm{Ba})>(\mathrm{Pb} \approx \mathrm{Fe})>(\mathrm{Ce} \approx \mathrm{U})>(\mathrm{Cr} \approx \mathrm{Hg} \approx \mathrm{Th}) .
$$

Manganese and barium generally had total concentration ratios greater than unity, indicating hyperaccumulation. This is not altogether surprising in light of the fact that $\mathrm{Mn}$ is an essential nutrient and $\mathrm{Ba}$ is a chemical analogue to $\mathrm{Ca}$. The total concentration ratios of $\mathrm{Cr}$, $\mathrm{Hg}$, and Th were generally $\sim 1 \mathrm{e}-2$.

Based on this data, there were few plant species that had consistently high concentration ratios at several sites. Among the more consistently high concentration ratios were:

- $\mathrm{Co}$ and $\mathrm{Ba}$ concentration ratios in tupelo, and

- $\mathrm{Cr}, \mathrm{Ba}$, and $\mathrm{Ce}$ in netted-chain fern. 
The average total concentration ratios are presented in Table 15. Additionally, the plant species with the greatest and the second greatest concentration ratio averages are identified. An important caveat needs to be reinforced before discussing this data set. First of all, comparisons between plant species using this data is compromised because the plants were not collected from soils from the same location, more specifically, they were not collected from soils with the same COC concentrations. This is important because concentration ratios typically vary with soil contaminant concentrations; specifically, they tend to increase as the soil contaminant concentrations increase. However, the average total concentration ratios are presented here because they provide a convenient and condensed metric for discussion.

Among the concentration ratios that stand out are:

- Co and Ba concentration ratios for tupelo,

- $\mathrm{Cr}, \mathrm{Th}$, and $\mathrm{U}$ concentrations ratios for sweetgum, and

- $\mathrm{Cr}, \mathrm{Hg}$, and $\mathrm{Ce}$ concentration ratios for the netted-chain fern.

Perhaps most remarkable about this data is that the leaf litter had unexpectedly high concentration ratios for a number of COC's, including $\mathrm{Co}, \mathrm{U}, \mathrm{Ba}, \mathrm{Ce}$, and $\mathrm{Pb}$. This is an important finding because leaf litter has a large annual biomass and would require relatively little effort to utilize for phytoimmobilization. It is also interesting to note that those leaf litter samples with the greatest concentration ratios consisted of relatively higher percentages of tupelo (Table 5 and Table 6)

Previous work has shown that some ferns can take up high concentrations of metals (Nishizonon et al. 1987, 1988, 1989, Morishita et al. 1992, Ichihasi et al. 1992, Neite et al. 1991). During the last few years fern species have been intensively screened for hyperaccumulation of trace elements by different laboratories. Hiraga et al. (1999) found that the hydroxyphenylpentanoic acid, a root exudate, enhanced the uptake and transport of alkaline and alkaline earth metals and heavy divalent metal ions. Ozeki et al. (2000) analyzed the accumulation of trace elements in 96 species of ferns by instrumental neutron activation analysis and found that trace element accumulation is highly variable and species dependent. Dryopteris erythrosora was found to take up large amounts of the lanthanides and rare earth elements under natural conditions (Ozeki et al. 2000). Recently, Ma et al. (2000) discovered that the Blake fern (Pteris vitatta) hyperaccumulates arsenic, with concentration ratios as high as 200. They theorize that the presence of arbuscular mycorrhizal fungi in these plants enhance the ability of these plants to take up high concentrations of arsenic. Arbuscular mycorrhizal fungi grow within plant roots and into the soil and greatly increase the ability of the plant to extract soil nutrients and solutes. 
WSRC-TR-2001-00032, REV. 0

Table 12. COCs concentrations ( $\mathrm{mg} / \mathrm{kg}$ dry wt.) of leaves recovered from the TNX-OD study site (table continues on next page).

\begin{tabular}{|c|c|c|c|c|c|c|c|c|c|c|c|c|c|}
\hline $\begin{array}{l}\text { Plant } \\
\text { Species }\end{array}$ & Type of Site & $\begin{array}{c}\text { Site } \\
\text { Location }^{(a)}\end{array}$ & $\mathrm{Hg}$ & $\mathrm{Cr}$ & $\mathrm{Co}$ & $\mathrm{Sr}$ & $\mathrm{Cs}$ & $\mathrm{Pb}$ & $\mathrm{U}$ & $\mathrm{Eu}^{(\mathrm{d})}$ & $\mathrm{Mn}$ & $\mathrm{Fe}$ & $\mathrm{Th}$ \\
\hline \multirow[t]{6}{*}{ Tupelo $^{(\mathrm{b})}$} & Non- & $\mathrm{Ctrl} 46$ & $\mathrm{BDL}^{(\mathrm{b})}$ & BDL & 1.7 & 177 & 0.14 & 0.57 & 0.65 & 0.87 & 3230 & 203 & 0.028 \\
\hline & contaminated & Ctrl 46d & BDL & BDL & 1.8 & 174 & 0.43 & 0.57 & 0.61 & 0.87 & 3097 & 207 & 0.032 \\
\hline & Contaminated & A-5 & 0.01 & 0.43 & 19.2 & 58.0 & 0.22 & 1.0 & 2.4 & 0.05 & 1712 & 145 & 10.3 \\
\hline & & B-3 & 0.05 & 0.47 & 20.2 & 47.6 & 0.11 & 0.42 & 8.9 & 0.03 & 1144 & 131 & 7.5 \\
\hline & & B-3w & BDL & 0.29 & 18.0 & 41.7 & 0.11 & 0.35 & 9.0 & 0.02 & 991 & 123 & 5.1 \\
\hline & & D-8 & 0.06 & 0.59 & 22.1 & 43.3 & 0.90 & 0.62 & 1.2 & 0.03 & 1349 & 179 & 2.0 \\
\hline \multirow[t]{5}{*}{ Sweetgum } & $\begin{array}{c}\text { Non- } \\
\text { contaminated }\end{array}$ & $\mathrm{Ctrl} 45$ & BDL & BDL & 0.15 & 102 & 0.17 & 0.34 & 0.04 & 0.05 & 1241 & 244 & 0.041 \\
\hline & Contaminated & A-5 & 0.03 & 0.65 & 0.74 & 89.4 & 0.15 & 0.95 & 1.7 & 0.01 & 1805 & 138 & 4.7 \\
\hline & & D-3 & 0.04 & 0.78 & 0.47 & 88.0 & 0.19 & 0.62 & 17.0 & 0.03 & 2268 & 214 & 6.8 \\
\hline & & B-4 & 0.02 & 0.61 & 0.37 & 54.1 & 0.10 & 0.35 & 7.0 & 0.02 & 1253 & 177 & 4.7 \\
\hline & & $B-4 d$ & 0.03 & 0.89 & 0.36 & 55.0 & 0.16 & 0.41 & 6.9 & 0.02 & 1258 & 185 & 3.9 \\
\hline \multirow[t]{4}{*}{ Cypress } & $\begin{array}{c}\text { Non- } \\
\text { contaminated }\end{array}$ & Ctrl 41 & 0.05 & BDL & 0.79 & 73 & 0.54 & 0.78 & BDL & 0.04 & 1314 & 259 & 0.008 \\
\hline & Contaminated & A-5 & 0.10 & 0.86 & 0.76 & 49.6 & 11.2 & 2.6 & 0.20 & 0.02 & 541 & 166 & 0.535 \\
\hline & & C-5 & 0.07 & 1.07 & 0.25 & 38.6 & 0.10 & 1.0 & 0.37 & 0.02 & 250 & 142 & 0.347 \\
\hline & & B-3 & 0.06 & 0.50 & 2.9 & 35.4 & 0.07 & 0.59 & 0.26 & 0.01 & 281 & 123 & 0.180 \\
\hline
\end{tabular}

\footnotetext{
(a) Site location are presented in Figure 8

(b) Leaf samples were collected between November 9, 1999 and March 15, 2000.

(c) $\mathrm{BDL}=$ Below detection limit

(d) $\mathrm{Eu}$ is an analog for Ac.
} 
WSRC-TR-2001-00032, REV. 0

Table 12 (Continuation). COCs concentrations (mg/kg dry wt.) of leaves recovered from the TNX-OD study site.

\begin{tabular}{|c|c|c|c|c|c|c|c|c|c|c|c|c|c|}
\hline $\begin{array}{l}\text { Plant } \\
\text { Species }\end{array}$ & Type of Site & $\begin{array}{c}\text { Site } \\
\text { Location }^{(a)}\end{array}$ & $\mathrm{Hg}$ & $\mathrm{Cr}$ & Co & $\mathrm{Sr}$ & Cs & $\mathrm{Pb}$ & $\mathrm{U}$ & $\mathrm{Eu}^{(\mathrm{c})}$ & $\mathrm{Mn}$ & $\mathrm{Fe}$ & $\mathrm{Th}$ \\
\hline \multirow[t]{6}{*}{ Water oak $^{(\mathrm{b})}$} & \multirow{3}{*}{$\begin{array}{c}\text { Non- } \\
\text { contaminated }\end{array}$} & $\mathrm{Ctrl} 41$ & $\mathrm{BDL}^{(\mathrm{b})}$ & $\mathrm{BDL}$ & 0.24 & 40.2 & 0.26 & 0.22 & BDL & 0.02 & 3469 & 146 & 0.018 \\
\hline & & Ctrl 42 & 0.02 & BDL & 0.43 & 48.1 & 0.15 & 0.27 & BDL & 0.03 & 3241 & 100 & 0.009 \\
\hline & & Ctrl 44 & 0.02 & $\mathrm{BDL}$ & 0.09 & 25 & 0.05 & 0.19 & $\mathrm{BDL}$ & 0.01 & 967 & 75 & 0.011 \\
\hline & \multirow[t]{3}{*}{ Contaminated } & A-5w & 0.06 & 0.35 & 0.34 & 54.9 & 0.16 & 0.62 & 0.10 & 0.04 & 2726 & 183 & 1.5 \\
\hline & & B-3 & 0.06 & 0.35 & 0.76 & 52.4 & 0.12 & 0.31 & 0.05 & 0.03 & 2161 & 159 & 1.3 \\
\hline & & D-8 & 0.01 & 0.41 & 1.39 & 26.6 & 0.14 & 0.32 & 1.2 & 0.02 & 1701 & 188 & 2.1 \\
\hline \multirow{6}{*}{$\begin{array}{l}\text { Loblolly } \\
\text { Pine }\end{array}$} & \multirow{3}{*}{$\begin{array}{c}\text { Non- } \\
\text { contaminated }\end{array}$} & Ctrl 41 & BDL & BDL & 0.45 & 14.3 & 0.31 & 0.20 & BDL & 0.006 & 1792 & 130 & 0.010 \\
\hline & & Ctrl 42 & 0.09 & BDL & 0.75 & 16.9 & 0.15 & 0.22 & BDL & 0.005 & 1623 & 100 & 0.008 \\
\hline & & $\mathrm{Ctrl} 44$ & BDL & $\mathrm{BDL}$ & 0.22 & 10.1 & 0.10 & 0.24 & $\mathrm{BDL}$ & 0.005 & 716 & 90 & $\mathrm{BDL}$ \\
\hline & \multirow[t]{3}{*}{ Contaminated } & A-5 & 0.02 & 0.41 & 0.45 & 15.8 & 0.06 & 0.56 & 0.11 & 0.006 & 969 & 69 & 0.13 \\
\hline & & C-5 & 0.02 & 0.70 & 0.16 & 8.8 & 0.21 & 0.78 & 0.81 & 0.008 & 308 & 79 & 0.24 \\
\hline & & D-8 & 0.06 & 0.54 & 1.78 & 11.2 & 0.09 & 0.40 & 0.06 & 0.007 & 753 & 70 & 0.24 \\
\hline \multirow[t]{9}{*}{ Red Maple } & $\begin{array}{c}\text { Non- } \\
\text { contaminated }\end{array}$ & Ctrl 43 & 0.03 & BDL & 0.61 & 108 & 0.41 & 1.1 & 0.03 & 0.05 & 2293 & 309 & BDL \\
\hline & \multirow[t]{8}{*}{ Contaminated } & $A-5$ & 0.06 & 0.47 & 0.56 & 59.5 & 0.77 & 0.74 & 0.21 & 0.02 & 846 & 225 & 0.34 \\
\hline & & $A-5 w$ & 0.05 & 0.50 & 0.72 & 45.2 & 0.09 & 0.63 & 0.28 & 0.02 & 959 & 250 & 0.22 \\
\hline & & C-5 & 0.08 & 1.2 & 0.19 & 41.0 & 0.52 & 1.2 & 8.1 & 0.02 & 1077 & 179 & 0.51 \\
\hline & & $C-5 d$ & 0.06 & 0.9 & 0.15 & 66.4 & 0.19 & 1.1 & 7.7 & 0.02 & 995 & 165 & 0.46 \\
\hline & & B-5 & 0.07 & 0.62 & 0.32 & 51.4 & 0.15 & 0.70 & 0.21 & 0.01 & 580 & 258 & 0.37 \\
\hline & & $B-5 w$ & 0.02 & 0.65 & 0.39 & 56.7 & 0.08 & 0.89 & 0.71 & 0.01 & 594 & 300 & 0.28 \\
\hline & & B-3 & 0.03 & 0.52 & 6.5 & 80.3 & 0.14 & 0.68 & 1.1 & 0.02 & 816 & 208 & 0.90 \\
\hline & & B-3w & 0.06 & 0.38 & 6.8 & 75.4 & 0.08 & 0.74 & 0.81 & 0.02 & 776 & 207 & 0.70 \\
\hline \multirow{7}{*}{ Leaf litter ${ }^{(\mathrm{d})}$} & \multirow{3}{*}{$\begin{array}{c}\text { Non- } \\
\text { contaminated }\end{array}$} & Ctrl 41 & 0.06 & $\mathrm{BDL}$ & 0.77 & 37.7 & 0.94 & 0.80 & 0.02 & 0.02 & 1524 & 183 & 0.024 \\
\hline & & Ctrl 42 & 0.04 & BDL & 5.3 & 49.8 & 0.11 & 1.32 & BDL & 0.03 & 1456 & 159 & 0.027 \\
\hline & & Ctrl 44 & $\mathrm{BDL}$ & $\mathrm{BDL}$ & 0.52 & 98.2 & 0.20 & 0.64 & 0.02 & 0.12 & 2025 & 188 & 0.025 \\
\hline & \multirow[t]{4}{*}{ Contaminated } & A-5 & 0.06 & 0.52 & 1.89 & 62.2 & 1.7 & 0.81 & 0.55 & 0.02 & 883 & 187 & 2.5 \\
\hline & & C-5 & 0.07 & 1.24 & 0.24 & 42.4 & 0.23 & 1.2 & 2.0 & 0.02 & 651 & 216 & 0.7 \\
\hline & & B-5 & 0.05 & 0.52 & 0.83 & 49.9 & 0.09 & 0.83 & 1.2 & 0.02 & 582 & 186 & 1.9 \\
\hline & & B-3 & 0.04 & 0.60 & 8.86 & 50.9 & 0.09 & 0.69 & 3.7 & 0.02 & 745 & 177 & 2.6 \\
\hline
\end{tabular}


WSRC-TR-2001-00032, REV. 0

(a) Site location are presented in Figure 8; w- washed control; d- duplicate. Leaf samples were collected between November 9, 1999 and March 15, 2000.

(b) $\mathrm{BDL}=$ Below detection limit

(c) $\mathrm{Eu}$ is an analog for Ac.

(d) This was an assorted subsample taken directly from the leaf-litter collection baskets; the remainder of the sample was sorted by species. 
WSRC-TR-2001-00032, REV. 0

Table 13. Correlation coefficients (r) between $\mathrm{Mn}$ or Fe and COC total concentration ratios (CR-T).

\begin{tabular}{ccc}
\hline COC & Mn CR-T & Fe CR-T \\
\hline Ba (an analog for Ra) & 0.26 & $0.64^{* *}$ \\
$\mathrm{Ce}($ an analog for Ac) & $0.69 * *$ & $0.53^{*}$ \\
$\mathrm{Co}$ & 0.41 & 0.30 \\
$\mathrm{Cr}$ & $0.77^{* *}$ & $0.78^{* *}$ \\
$\mathrm{Fe}$ & $0.78^{* *}$ & -- \\
$\mathrm{Hg}$ & 0.08 & 0.32 \\
$\mathrm{Mn}$ & -- & $0.78^{* *}$ \\
$\mathrm{~Pb}$ & $0.82^{* *}$ & $0.77^{* *}$ \\
$\mathrm{U}$ & $0.79^{* *}$ & $0.61 * *$ \\
\hline
\end{tabular}

(a) $\mathrm{CR}-\mathrm{T}=$ plant concentration/total soil concentration, Soil-A $=$ available soil concentration, $\mathrm{CR}-\mathrm{A}=$ plant concentration/available soil concentration.

(b) $*$ identifies a significant correlation at the $\leq 0.05$ level of probability for 17 observations (critical $\mathrm{r}$ is \pm 0.46 ).

$* *$ identifies a significant correlation at the $\leq 0.01$ level of probability for 17 observations (critical $r$ is \pm 0.58 ). 
WSRC-TR-2001-00032, REV. 0

Table 14. Total soil and plant concentrations (mg/kg; dry wt.) and total concentration ratios (CR-T; plant conc./total soil conc.) (table continues on following page).

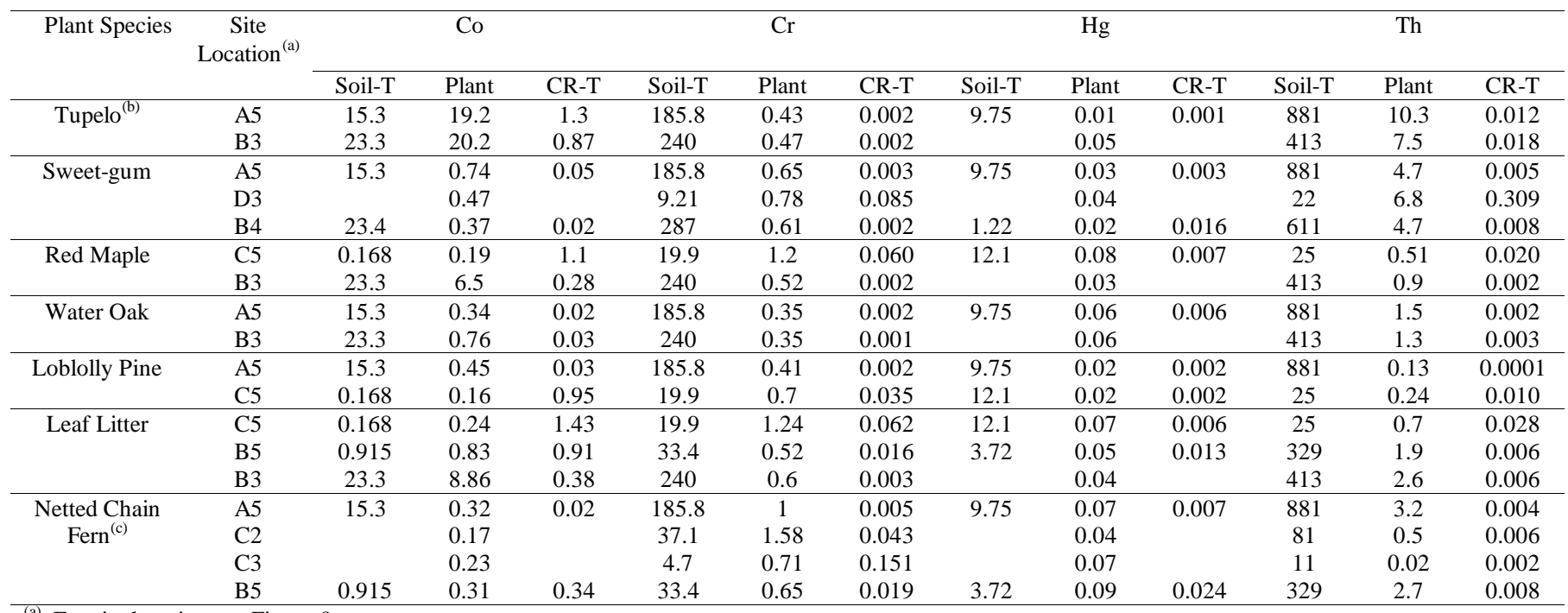

\footnotetext{
(a) For site location see Figure 8.

(b) Leaf samples were collected between November 9, 1999 and March 15, 2000

(c) Netted chain fern sample was collected March 22, 2000.
} 
WSRC-TR-2001-00032, REV. 0 Table 14 (Continuation). Total soil and plant concentrations (mg/kg; dry wt.) and total concentration ratios (CR-T; plant conc./total soil conc.).

\begin{tabular}{|c|c|c|c|c|c|c|c|c|c|c|c|c|c|}
\hline \multirow[t]{2}{*}{ Plant Species } & \multirow{2}{*}{$\begin{array}{c}\text { Site } \\
\text { Location }^{(a)}\end{array}$} & \multicolumn{3}{|c|}{$\mathrm{Ba}^{(\mathrm{d})}$} & \multicolumn{3}{|c|}{$\mathrm{Ce}^{(\mathrm{d})}$} & \multicolumn{3}{|c|}{$\mathrm{Pb}$} & \multicolumn{3}{|c|}{$\mathrm{Mn}$} \\
\hline & & Soil-T & Plant & CR-T & Soil-T & Plant & CR-T & Soil-T & Plant & CR-T & Soil-T & Plant & CR-T \\
\hline \multirow[t]{2}{*}{ Tupelo $^{(b)}$} & A5 & 15.2 & 324 & 21.3 & 69 & 0.43 & 0.006 & 17.2 & 1 & 0.058 & 662 & 1712 & 2.6 \\
\hline & B3 & 21 & 169 & 8.0 & 64 & 0.3 & 0.005 & 16.3 & 0.42 & 0.026 & 250 & 1144 & 4.6 \\
\hline \multirow[t]{3}{*}{ Sweet-gum } & A5 & 15.2 & 183 & 12.0 & 69 & 1.4 & 0.020 & 17.2 & 0.95 & 0.055 & 662 & 1805 & 2.7 \\
\hline & D3 & 3.6 & 188 & 52.2 & 9.2 & 0.83 & 0.090 & 2 & 0.62 & 0.310 & 96 & 2268 & 23.6 \\
\hline & B4 & 15.6 & 72 & 4.6 & 68 & 0.64 & 0.009 & 14.7 & 0.35 & 0.024 & 230 & 1253 & 5.4 \\
\hline \multirow[t]{2}{*}{ Red Maple } & $\mathrm{C} 5$ & 4.8 & 46 & 9.6 & 5.7 & 1.11 & 0.195 & 2 & 1.2 & 0.600 & 17 & 1077 & 63.4 \\
\hline & B3 & 21 & 97 & 4.6 & 64 & 0.7 & 0.011 & 16.3 & 0.7 & 0.043 & 250 & 580 & 2.3 \\
\hline \multirow[t]{2}{*}{ Water Oak } & A5 & 15.2 & 130 & 8.6 & 69 & 1.5 & 0.022 & 17.7 & 0.62 & 0.035 & 662 & 2726 & 4.1 \\
\hline & B3 & 21 & 129 & 6.1 & 64 & 0.98 & 0.015 & 16.3 & 0.31 & 0.019 & 250 & 2161 & 8.6 \\
\hline \multirow[t]{2}{*}{ Loblolly Pine } & A5 & 15.2 & 15 & 1.0 & 69 & 0.44 & 0.006 & 17.2 & 0.56 & 0.033 & 662 & 969 & 1.5 \\
\hline & $\mathrm{C} 5$ & 4.8 & 8 & 1.7 & 5.7 & 1.07 & 0.188 & 2 & 0.78 & 0.390 & 17 & 308 & 18.1 \\
\hline \multirow[t]{3}{*}{ Leaf Litter } & $\mathrm{C} 5$ & 4.8 & 78 & 16.3 & 5.7 & 1.11 & 0.195 & 2 & 1.2 & 0.600 & 17 & 651 & 38.3 \\
\hline & B5 & 30 & 58 & 1.9 & 19 & 0.53 & 0.028 & 11 & 0.83 & 0.075 & 36 & 582 & 16.2 \\
\hline & B3 & 21 & 106 & 5.0 & 64 & 0.57 & 0.009 & 16.3 & 0.69 & 0.042 & 250 & 745 & 3.0 \\
\hline Netted Chain & A5 & 15.2 & 95 & 6.3 & 69 & 4.9 & 0.071 & 17.2 & 0.32 & 0.019 & 662 & 246 & 0.4 \\
\hline \multirow{3}{*}{ Fern ${ }^{(\mathrm{c})}$} & $\mathrm{C} 2$ & 5 & 70 & 14.0 & 34 & 3.7 & 0.109 & 4.5 & 0.18 & 0.040 & 82 & 85 & 1.0 \\
\hline & $\mathrm{C} 3$ & 4.8 & 84 & 17.5 & 3.9 & 2.4 & 0.615 & 1.6 & 0.22 & 0.138 & 6.7 & 313 & 46.7 \\
\hline & B5 & 30 & 67 & 2.2 & 19 & 3.8 & 0.200 & 11 & 0.23 & 0.021 & 36 & 226 & 6.3 \\
\hline
\end{tabular}

\footnotetext{
(b) For site location see Figure 8.

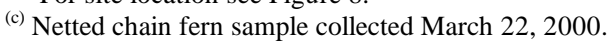

(d) $\mathrm{Ba}$ is an analog for $\mathrm{Ra}$ and $\mathrm{Ce}$ is an analog for Ac.
}

${ }^{(a)}$ Leaf samples were collected between November 9, 1999 and March 15, 2000. 
WSRC-TR-2001-00032, REV. 0 Table 14 (Continuation). Total soil and plant concentrations (mg/kg; dry wt.) and total concentration ratios (CR-T; plant conc./total soil conc.).

\begin{tabular}{|c|c|c|c|c|c|c|c|}
\hline \multirow[t]{2}{*}{ Plant Species } & \multirow{2}{*}{$\begin{array}{c}\text { Site } \\
\text { Location }^{(a)}\end{array}$} & \multicolumn{3}{|c|}{$\mathrm{U}$} & \multicolumn{3}{|c|}{$\mathrm{Fe}$} \\
\hline & & Soil-T & Plant & CR-T & Soil-T & Plant & CR-T \\
\hline \multirow{2}{*}{ Tupelo $^{(\mathrm{b})}$} & A5 & 288 & 2.4 & 0.008 & 27068 & 145 & 0.005 \\
\hline & B3 & 627 & 8.9 & 0.014 & 8789 & 131 & 0.015 \\
\hline \multirow{3}{*}{ Sweet-gum } & A5 & 288 & 1.7 & 0.006 & 27068 & 138 & 0.005 \\
\hline & D3 & 9.66 & 17 & 1.760 & 2977 & 214 & 0.072 \\
\hline & B4 & 348 & 7 & 0.020 & 21457 & 177 & 0.008 \\
\hline \multirow[t]{2}{*}{ Red Maple } & C5 & 1.4 & 8.1 & 5.786 & 3332 & 179 & 0.054 \\
\hline & B3 & 627 & 1.1 & 0.002 & 8759 & 258 & 0.029 \\
\hline \multirow[t]{2}{*}{ Water Oak } & A5 & 288 & 0.1 & 0.0003 & 27068 & 183 & 0.007 \\
\hline & B3 & 627 & 0.05 & 0.0001 & 8789 & 159 & 0.018 \\
\hline \multirow[t]{2}{*}{ Loblolly Pine } & A5 & 288 & 0.11 & 0.0004 & 27068 & 69 & 0.003 \\
\hline & C5 & 1.4 & 0.81 & 0.579 & 3332 & 79 & 0.024 \\
\hline \multirow[t]{3}{*}{ Leaf Litter } & C5 & 1.4 & 2 & 1.429 & 3332 & 216 & 0.065 \\
\hline & B5 & 44 & 1.2 & 0.027 & 19954 & 186 & 0.009 \\
\hline & B3 & 627 & 3.7 & 0.006 & 8759 & 177 & 0.020 \\
\hline \multirow{4}{*}{$\begin{array}{l}\text { Netted Chain } \\
\text { Fern }^{(c)}\end{array}$} & A5 & 288 & 1.42 & 0.005 & 27068 & 239 & 0.009 \\
\hline & $\mathrm{C} 2$ & 144 & 0.25 & 0.002 & 5927 & 98 & 0.017 \\
\hline & C3 & 1.53 & 0.09 & 0.059 & 1820 & 93 & 0.051 \\
\hline & B5 & 44 & 1.1 & 0.025 & 19954 & 176 & 0.009 \\
\hline
\end{tabular}

(a) Leaf samples were collected between November 9, 1999 and March 15, 2000.

(b) For site location see Figure 8.

${ }^{(c)}$ Netted chain fern sample collected March 22, 2000. 
WSRC-TR-2001-00032, REV. 0

Table 15. Average total concentration ratios (CR-T; plant conc./total soil conc.) values.

\begin{tabular}{|c|c|c|c|c|c|c|c|c|c|c|}
\hline Plant Species & $\mathrm{Co}$ & $\mathrm{Cr}$ & $\mathrm{Hg}$ & Th & $\mathrm{U}$ & $\mathrm{Ba}^{(\mathrm{c})}$ & $\mathrm{Ce}^{(\mathrm{c})}$ & $\mathrm{Pb}$ & $\mathrm{Mn}$ & $\mathrm{Fe}$ \\
\hline Tupelo & 1.09 & 0.002 & 0.001 & 0.015 & 0.011 & 14.7 & 0.005 & 0.042 & 3.6 & 0.010 \\
\hline Sweetgum & 0.04 & 0.043 & 0.009 & 0.158 & 0.595 & 23 & 0.040 & 0.130 & 10.6 & 0.028 \\
\hline \multirow[t]{2}{*}{ Red Maple } & 0.28 & 0.031 & 0.007 & 0.011 & 0.002 & 7.1 & 0.011 & 0.43 & 2.3 & 0.029 \\
\hline & \pm 0.58 & \pm 0.041 & & \pm 0.013 & & \pm 3.5 & & \pm 0.39 & & \\
\hline Water Oak & 0.03 & 0.002 & 0.006 & 0.002 & 0.0002 & 7.3 & 0.019 & 0.027 & 6.4 & 0.012 \\
\hline Loblolly Pine & \pm 0.65 & \pm 0.023 & & \pm 0.007 & \pm 0.409 & \pm 0.5 & \pm 0.13 & \pm 0.25 & \pm 11.8 & \pm 0.01 \\
\hline \multirow[t]{2}{*}{ Leaf Litter } & 0.64 & 0.009 & 0.009 & 0.006 & 0.487 & 7.7 & 0.077 & 0.239 & 19.1 & 0.031 \\
\hline & \pm 0.52 & \pm 0.03 & & \pm 0.013 & \pm 0.82 & \pm 7.5 & \pm 0.100 & \pm 0.311 & \pm 17.8 & \pm 0.03 \\
\hline Netted-Chain & 0.18 & 0.085 & 0.016 & 0.005 & 0.023 & 10 & 0.249 & 0.054 & 13.6 & 0.021 \\
\hline Fern $^{(\mathrm{d})}$ & \pm 2.62 & \pm 0.06 & & \pm 0.003 & \pm 0.21 & \pm 6.4 & \pm 0.23 & \pm 0.111 & \pm 19.4 & \pm 0.02 \\
\hline Greatest CR-T & Tupelo & $\begin{array}{l}\text { Netted- } \\
\text { chain } \\
\text { Fern }\end{array}$ & $\begin{array}{l}\text { Netted- } \\
\text { chain Fern }\end{array}$ & $\begin{array}{l}\text { Sweet- } \\
\text { gum }\end{array}$ & Sweetgum & Sweetgum & $\begin{array}{l}\text { Netted- } \\
\text { chain } \\
\text { Fern }\end{array}$ & Leaf litter & $\begin{array}{l}\text { Leaf } \\
\text { Litter }\end{array}$ & $\begin{array}{l}\text { Leaf } \\
\text { Litter }\end{array}$ \\
\hline
\end{tabular}

(a) The number of observations for each mean varies; tupelo $=2$, sweetgum $=3$, red maple $=1$ or 2 , water oat $=2$, pine $=2$, leaf litter $=3$, Netted Chain Fern between 2 and 5. The site locations from which plant and soil samples were collected vary between plant species, thus, concentration ratio comparisons between plant species is compromised.

(b) Tree leaves were collected between November 9, 1999 and March 15, 2000.

${ }^{\text {(c) }} \mathrm{Ba}$ is an analog for $\mathrm{Ra}$ and $\mathrm{Ce}$ is an analog for Ac.

(d) This was an assorted subsample taken directly from the leaf-litter collection baskets; the remainder of the sample was sorted by species. 
The concentration ratios of several plant species were compared at three coordinates where COC concentrations were relatively high: coordinates A-5 (Table 16), B-3 (Table 17), and C5 (Table 18). These data sets are important because the soil COC concentrations at any given coordinate are assumed to be similar between plant species. Unfortunately, there are no replicates in this data.

Among the concentration ratios from coordinate A-5 (Table 16) that are exceptionally large are:

- Co, Th, and Ba concentration ratios for tupelo, and

- Ce concentration ratio for netted-chain fern.

None of the concentration ratios from coordinate B-3 (Table 17) appear exceptionally large. Among the concentration ratios from coordinate C-5 (Table 18) that are exceptionally large are:

- U concentration ratio for red maple, and

- U concentration ratio for leaf litter.

Another important observation from these data is that the concentration ratios for a given $\mathrm{COC}$ at a given coordinate location appear to have less difference between the various plant species, than when the coordinate location varied. This suggests that some of the apparent differences between the plant species may be attributed to factors other than the plants themselves, factors such as analytical or laboratory error. 
WSRC-TR-2001-00032, REV. 0

Table 16. COC concentrations ( $\mathrm{mg} / \mathrm{kg}$; dry weight) and total concentration ratios (CR-T; plant conc./total soil conc.) from leaves and soils collected from coordinate A-5 at the TNX-OD study site.

\begin{tabular}{|c|c|c|c|c|c|c|c|c|c|c|}
\hline \multirow[t]{2}{*}{ Soil Conc. $(\mathrm{mg} / \mathrm{kg})$} & \multicolumn{2}{|c|}{$\begin{array}{c}\text { Co } \\
15.3 \\
\end{array}$} & \multicolumn{2}{|c|}{$\begin{array}{c}\mathrm{Cr} \\
185.8\end{array}$} & \multicolumn{2}{|c|}{$\begin{array}{c}\mathrm{Hg} \\
9.75\end{array}$} & \multicolumn{2}{|c|}{$\begin{array}{l}\text { Th } \\
881\end{array}$} & \multicolumn{2}{|c|}{$\begin{array}{c}\mathrm{U} \\
288\end{array}$} \\
\hline & Plant & CR-T & Plant & CR-T & Plant & CR-T & Plant & CR-T & Plant & CR-T \\
\hline Tupelo $^{(a)}$ & 19.2 & 1.3 & 0.43 & 0.002 & 0.01 & 0.001 & 10.3 & 0.012 & 2.4 & 0.008 \\
\hline Sweetgum & 0.74 & 0.05 & 0.65 & 0.003 & 0.03 & 0.003 & 4.7 & 0.005 & 1.7 & 0.006 \\
\hline Water Oak & 0.34 & 0.02 & 0.35 & 0.002 & 0.06 & 0.006 & 1.5 & 0.002 & 0.1 & 0.0003 \\
\hline Loblolly Pine & 0.45 & 0.03 & 0.41 & 0.002 & 0.02 & 0.002 & 0.13 & 0.0001 & 0.11 & 0.0004 \\
\hline Leaf Litter ${ }^{(b)}$ & 1.8 & 0.118 & 0.52 & 0.003 & 0.07 & 0.006 & 2.5 & 0.003 & 0.55 & 0.002 \\
\hline Netted-chain Fern ${ }^{(a)}$ & 0.32 & 0.02 & 1 & 0.005 & 0.07 & 0.007 & 3.2 & 0.004 & 1.42 & 0.005 \\
\hline
\end{tabular}

(a) Leaf samples were collected between November 9, 1999 and March 15, 2000.

(b) This was an assorted subsample taken directly from the leaf-litter collection baskets; the remainder of the sample was sorted by species.

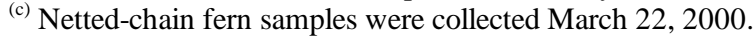

Table 16 (Continuation). COC concentrations ( $\mathrm{mg} / \mathrm{kg}$; dry weight) and total concentration ratios (CR-T; plant conc./total soil conc.) from leaves and soils collected from coordinate A-5 at the TNX-OD study site.

\begin{tabular}{|c|c|c|c|c|c|c|c|c|c|c|}
\hline \multirow{2}{*}{ Total Soil (mg/kg) } & \multicolumn{2}{|c|}{$\begin{array}{c}\mathrm{Ba}^{(\mathrm{d})} \\
15.2 \\
\end{array}$} & \multicolumn{2}{|c|}{$\begin{array}{c}\mathrm{Ce}^{(\mathrm{d})} \\
69\end{array}$} & \multicolumn{2}{|c|}{$\begin{array}{c}\mathrm{Pb} \\
17.2\end{array}$} & \multicolumn{2}{|c|}{$\begin{array}{l}\mathrm{Mn} \\
662 \\
\end{array}$} & \multicolumn{2}{|c|}{$\begin{array}{c}\mathrm{Fe} \\
27068\end{array}$} \\
\hline & Plant & $\mathrm{CR}$ & Plant & CR-T & Plant & CR-T & Plant & CR-T & Plant & CR-T \\
\hline Tupelo $^{(a)}$ & 324 & 21.3 & 0.43 & 0.006 & 1 & 0.058 & 1712 & 2.6 & 145 & 0.005 \\
\hline Sweetgum & 183 & 12.0 & 1.4 & 0.020 & 0.95 & 0.055 & 1805 & 2.7 & 138 & 0.005 \\
\hline Water Oak & 130 & 8.6 & 1.5 & 0.022 & 0.62 & 0.035 & 2726 & 4.1 & 183 & 0.007 \\
\hline Loblolly Pine & 15 & 1.0 & 0.44 & 0.006 & 0.56 & 0.033 & 969 & 1.5 & 69 & 0.003 \\
\hline Leaf Litter ${ }^{(b)}$ & 107 & 7.4 & 0.93 & 0.013 & 0.81 & 0.047 & 883 & 1.33 & 187 & 0.007 \\
\hline Netted-chain Fern ${ }^{(c)}$ & 95 & 6.3 & 4.9 & 0.071 & 0.32 & 0.019 & 246 & 0.4 & 239 & 0.009 \\
\hline
\end{tabular}

(a) Leaf samples were collected between November 9, 1999 and March 15, 2000.

(b) This was an assorted subsample taken directly from the leaf-litter collection baskets; the remainder of the sample was sorted by species.

(c) Netted-chain fern samples were collected March 22, 2000.

(d) $\mathrm{Ba}$ is an analog for $\mathrm{Ra}$ and $\mathrm{Ce}$ is an analog for Ac. 
WSRC-TR-2001-00032, REV. 0

Table 17. COC concentrations ( $\mathrm{mg} / \mathrm{kg}$; dry weight) and total concentration ratios (CR-T; plant conc./total soil conc.) from leaves and soils collected from coordinate B-3 at the TNX-OD study site.

\begin{tabular}{|c|c|c|c|c|c|c|c|c|c|c|}
\hline Total Soil (mg/kg) & \multicolumn{2}{|c|}{$\begin{array}{c}\text { Co } \\
23.3 \\
\end{array}$} & \multicolumn{2}{|c|}{$\begin{array}{c}\mathrm{Cr} \\
240\end{array}$} & \multicolumn{2}{|c|}{$\begin{array}{c}\mathrm{Hg} \\
0.03\end{array}$} & \multicolumn{2}{|c|}{$\begin{array}{c}\text { Th } \\
413\end{array}$} & \multicolumn{2}{|c|}{$\begin{array}{c}\mathrm{U} \\
627\end{array}$} \\
\hline Tupelo $^{(a)}$ & 20.2 & 0.87 & 0.47 & 0.002 & 0.05 & NA & 7.5 & 0.018 & 8.9 & 0.014 \\
\hline Water Oak & 0.76 & 0.03 & 0.35 & 0.001 & 0.06 & NA & 1.3 & 0.003 & 0.05 & 0.0001 \\
\hline Leaf Litter ${ }^{(b)}$ & 8.86 & 0.38 & 0.6 & 0.003 & 0.04 & NA & 2.6 & 0.006 & 3.7 & 0.006 \\
\hline
\end{tabular}

(a) Leaf samples were collected between November 9, 1999 and March 15, 2000.

(b) This was an assorted subsample taken directly from the leaf-litter collection baskets; the remainder of the sample was sorted by species.

Table 17 (Continuation). COC concentrations ( $\mathrm{mg} / \mathrm{kg}$; dry weight) and total concentration ratios (CR-T; plant conc./total soil conc.) from leaves and soils collected from coordinate B-3 at the TNX-OD study site.

\begin{tabular}{|c|c|c|c|c|c|c|c|c|c|c|}
\hline Total Soil (mg/kg) & \multicolumn{2}{|c|}{$\begin{array}{c}\mathrm{Ba}^{(\mathrm{c})} \\
21\end{array}$} & \multicolumn{2}{|c|}{$\begin{array}{c}\mathrm{Ce}^{(\mathrm{c})} \\
64\end{array}$} & \multicolumn{2}{|c|}{$\begin{array}{c}\mathrm{Pb} \\
16.3\end{array}$} & \multicolumn{2}{|c|}{$\begin{array}{l}\text { Mn } \\
250\end{array}$} & \multicolumn{2}{|c|}{$\begin{array}{c}\mathrm{Fe} \\
8789\end{array}$} \\
\hline Tupelo $^{\text {(a) }}$ & 169 & 8.0 & 0.3 & 0.005 & 0.42 & 0.026 & 1144 & 4.6 & 131 & 0.015 \\
\hline Water Oak & 129 & 6.1 & 0.98 & 0.015 & 0.31 & 0.019 & 2161 & 8.6 & 159 & 0.018 \\
\hline Leaf Litter ${ }^{(b)}$ & 106 & 5.0 & 0.57 & 0.009 & 0.69 & 0.042 & 745 & 3.0 & 177 & 0.020 \\
\hline
\end{tabular}

(a) Leaf samples were collected between November 9, 1999 and March 15, 2000.

(b) This was an assorted subsample taken directly from the leaf-litter collection baskets; the remainder of the sample was sorted by species.

(c) $\mathrm{Ba}$ is an analog for $\mathrm{Ra}$ and $\mathrm{Ce}$ is an analog for Ac. 
WSRC-TR-2001-00032, REV. 0

Table 18. COC concentrations ( $\mathrm{mg} / \mathrm{kg}$; dry weight) and total concentration ratios (CR-T; plant conc./total soil conc.) from leaves and soils collected from coordinate C-5 at the TNX-OD study site.

\begin{tabular}{|c|c|c|c|c|c|c|c|c|c|c|}
\hline Total Soil (mg/kg) & \multicolumn{2}{|c|}{$\begin{array}{c}\text { Co } \\
0.168\end{array}$} & \multicolumn{2}{|c|}{$\begin{array}{c}\mathrm{Cr} \\
19.9\end{array}$} & \multicolumn{2}{|c|}{$\begin{array}{c}\mathrm{Hg} \\
12.1\end{array}$} & \multicolumn{2}{|c|}{$\begin{array}{l}\text { Th } \\
25\end{array}$} & \multicolumn{2}{|c|}{$\begin{array}{c}\mathrm{U} \\
1.4\end{array}$} \\
\hline Red Maple $^{(a)}$ & 0.19 & 1.1 & 1.2 & 0.060 & 0.08 & 0.007 & 0.51 & 0.020 & 8.1 & 5.78 \\
\hline Leaf Litter ${ }^{(\mathrm{b})}$ & 0.24 & 1.43 & 1.24 & 0.062 & 0.07 & 0.006 & 0.7 & 0.028 & 2 & 1.429 \\
\hline
\end{tabular}

(a) Leaf samples were collected between November 9, 1999 and March 15, 2000.

(b) Includes several plant species.

Table 18 (Continuation). COC concentrations ( $\mathrm{mg} / \mathrm{kg}$; dry weight) and total concentration ratios (CR-T; plant conc./total soil conc.) from leaves and soils collected from coordinate C-5 at the TNX-OD study site.

\begin{tabular}{|c|c|c|c|c|c|c|c|c|c|c|}
\hline Total Soil (mg/kg) & \multicolumn{2}{|c|}{$\begin{array}{c}\mathrm{Ba}^{(\mathrm{c})} \\
4.8\end{array}$} & \multicolumn{2}{|c|}{$\begin{array}{c}\mathrm{Ce}^{(\mathrm{c})} \\
5.7\end{array}$} & \multicolumn{2}{|c|}{$\begin{array}{l}\mathrm{Pb} \\
2.0\end{array}$} & \multicolumn{2}{|c|}{$\begin{array}{c}\mathrm{Mn} \\
17\end{array}$} & \multicolumn{2}{|c|}{$\begin{array}{c}\mathrm{Fe} \\
3332\end{array}$} \\
\hline Red Maple $^{(a)}$ & 46 & 9.6 & 1.11 & 0.195 & 1.2 & 0.600 & 1077 & 63.4 & 179 & 0.054 \\
\hline Leaf Litter ${ }^{(\mathrm{b})}$ & 78 & 16.3 & 1.11 & 0.195 & 1.2 & 0.600 & 651 & 38.3 & 216 & 0.065 \\
\hline
\end{tabular}

(a) Leaf samples were collected between November 9, 1999 and March 15, 2000.

(b) Includes several plant species.

(c) $\mathrm{Ba}$ is an analog for $\mathrm{Ra}$ and $\mathrm{Ce}$ is an analog for Ac. 
Not all of the herbaceous plants collected during the survey were chemically analyzed prior to the project being terminated. However, data was collected on various ferns. For the most part, the ferns that were sampled were collected from among the most contaminated areas, as well as from background areas. The plant concentrations are presented in Table 19 and the total concentration ratios are presented in Table 20. The total concentration ratios of the netted-chain fern tended to be higher in the non-contaminated soil. There was no compelling evidence that any one fern species had higher total concentrations ratios than the others, with one notable exception; the ebony spleenwort appeared to take up large amounts of Eu.

One of the uncertainties in this study was whether plant COC concentrations changed during the course of the year. To address this question, samples of netted-chain ferns were collected in March, April, and November from coordinate A-5 (Figure 10). For all elements analyzed, the plant concentrations increased three to ten fold during the growing season. Presumably, this may be the result of the plants growing vigorously during the spring, thereby taking up a lot of water and dissolved constituents. Over the course of the growing season, the water transpires from the leaves and the contaminants accumulate in the plant tissue. Another process that may be contributing to this trend is that the increased water uptake during the spring may dilute the plant contaminant concentration. This trend is ideal for the phytoimmobilization technology because the concentration of the COC would be at their maximum in the autumn, when the leaves would fall to the geomat. 
WSRC-TR-2001-00032, REV. 0

Table 19. COCs concentration in four fern plants $(\mathrm{mg} / \mathrm{kg}$; dry weight) collected at the TNX OD study site.

\begin{tabular}{|c|c|c|c|c|c|c|c|c|c|c|c|c|c|}
\hline Plant $^{(\mathrm{a})}$ & $\begin{array}{c}\text { Type of } \\
\text { Site }\end{array}$ & $\begin{array}{c}\text { Site } \\
\text { Location }^{(b)}\end{array}$ & $\mathrm{Hg}$ & $\mathrm{Cr}$ & $\mathrm{Co}$ & $\mathrm{Sr}$ & Cs & $\mathrm{Pb}$ & $\mathrm{U}$ & $\mathrm{Eu}^{(\mathrm{e})}$ & $\mathrm{Mn}$ & $\mathrm{Fe}$ & $\mathrm{Th}$ \\
\hline \multirow{11}{*}{$\begin{array}{l}\text { Netted-chain } \\
\text { Fern }\end{array}$} & Non-cont. & $\mathrm{K}-26$ & 0.07 & 7.9 & 1.4 & 51 & 0.7 & 0.96 & 0.25 & 0.13 & 1977 & 565 & 0.52 \\
\hline & \multirow[t]{10}{*}{ Cont. } & A-5 & 0.13 & 1.0 & 0.32 & 16.4 & 0.76 & 0.32 & 1.42 & 0.06 & 246 & 239 & 3.2 \\
\hline & & $A-5 w^{(c)}$ & 0.08 & 0.24 & 0.22 & 14.9 & 0.79 & 0.27 & 0.40 & 0.04 & 257 & 93 & $\mathrm{NA}^{(\mathrm{d})}$ \\
\hline & & $\mathrm{A}-7 \mathrm{w}^{(\mathrm{c})}$ & 0.06 & 0.32 & 0.24 & 14.8 & 0.24 & 0.17 & 0.56 & 0.04 & 304 & 94 & NA \\
\hline & & $\mathrm{B}-8 \mathrm{w}^{(\mathrm{c})}$ & 0.07 & 0.36 & 0.37 & 13.2 & 0.44 & 0.12 & 0.59 & 0.04 & 351 & 91 & NA \\
\hline & & C-2 & 0.04 & 1.58 & 0.17 & 15.1 & 0.26 & 0.18 & 0.25 & 0.04 & 85 & 98 & NA \\
\hline & & C-3 & 0.07 & 0.71 & 0.23 & 30.4 & 1.49 & 0.22 & 0.09 & 0.03 & 313 & 93 & NA \\
\hline & & B-5 & 0.09 & 0.65 & 0.31 & 15.3 & 0.61 & 0.23 & 1.1 & 0.05 & 226 & 176 & NA \\
\hline & & G-3 & 0.06 & 0.61 & 0.22 & 18.1 & 0.26 & 0.23 & 0.40 & 0.05 & 200 & 113 & NA \\
\hline & & A-4 & 0.08 & 0.54 & 0.30 & 18.0 & 0.30 & 0.21 & 0.65 & 0.06 & 347 & 117 & NA \\
\hline & & $\mathrm{A}-4 \mathrm{~d}^{(\mathrm{c})}$ & 0.05 & 0.69 & 0.29 & 16.7 & 0.39 & 0.19 & 0.59 & 0.05 & 318 & 116 & NA \\
\hline \multirow[t]{4}{*}{ Sensitive Fern } & Non-cont. & Ctrl 43 & 0.08 & $\mathrm{BDL}^{(\mathrm{d})}$ & 0.71 & 87 & 2.6 & 0.35 & BDL & 0.13 & 182 & 160 & NA \\
\hline & \multirow[t]{3}{*}{ Cont. } & $\mathrm{A}-7 \mathrm{~W}^{(\mathrm{c})}$ & 0.04 & BDL & 0.39 & 28.5 & 0.26 & 0.25 & 0.32 & 0.03 & 62 & 82 & NA \\
\hline & & $\mathrm{K}-18 \mathrm{w}^{(\mathrm{c})}$ & 0.04 & 0.30 & 0.27 & 30.7 & 0.63 & 0.16 & 1.1 & 0.05 & 58 & 83 & NA \\
\hline & & A-4 & 0.03 & 0.63 & 0.32 & 19.1 & 0.42 & 0.20 & 0.51 & 0.07 & 248 & 116 & NA \\
\hline \multirow{3}{*}{$\begin{array}{c}\text { Marginal } \\
\text { Wood Ferm. }\end{array}$} & Non-cont. & $\mathrm{K}-24$ & 0.04 & BDL & 1.00 & 37 & 0.50 & 0.26 & BDL & 0.51 & 131 & 244 & NA \\
\hline & \multirow[t]{2}{*}{ Cont. } & $\mathrm{K}-18 \mathrm{w}^{(\mathrm{c})}$ & 0.03 & 0.33 & 0.11 & 21.6 & 0.16 & 0.15 & 0.03 & 0.01 & 65 & 99 & NA \\
\hline & & D-7 & 0.03 & 0.59 & 0.31 & 13.2 & 1.56 & 0.41 & 0.07 & 0.01 & 96 & 75 & NA \\
\hline \multirow{5}{*}{$\begin{array}{c}\text { Ebony } \\
\text { Spleenwort }\end{array}$} & Non-cont. & Ctrl 44 & BDL & BDL & 0.09 & 24.1 & 0.41 & 0.21 & BDL & 0.05 & 54 & 108 & NA \\
\hline & \multirow[t]{4}{*}{ Cont. } & D-3 & 0.08 & 0.90 & 0.08 & 30.0 & 0.37 & 0.36 & 0.97 & 0.11 & 184 & 125 & NA \\
\hline & & D-4 & 0.04 & 0.52 & 0.03 & 17.5 & 1.50 & 0.15 & 0.03 & 0.04 & 45 & 73 & NA \\
\hline & & D-5 & 0.11 & 1.00 & 0.05 & 22.0 & 1.44 & 0.29 & 0.20 & 0.08 & 100 & 103 & NA \\
\hline & & D6 & 0.05 & 0.54 & 0.04 & 15.0 & 0.89 & 0.20 & 0.04 & 0.03 & 108 & 95 & NA \\
\hline
\end{tabular}

(a) Scientific names of plants presented in Appendix A; Samples collected on March 22, 2000.

(b) Site locations are presented in Figure 8.

(c) $\mathrm{w}=$ washed control, $\mathrm{d}=$ duplicate.

(d) $\mathrm{NA}=$ not available due to data not satisfying QA requirements. BDL = below detection limits.

${ }^{(e)} \mathrm{Eu}$ is an analog for Ac. 
WSRC-TR-2001-00032, REV. 0

Table 20. Total concentration ratios (plant conc./total soil conc.) in four fern plants collected at the TNX OD study site.

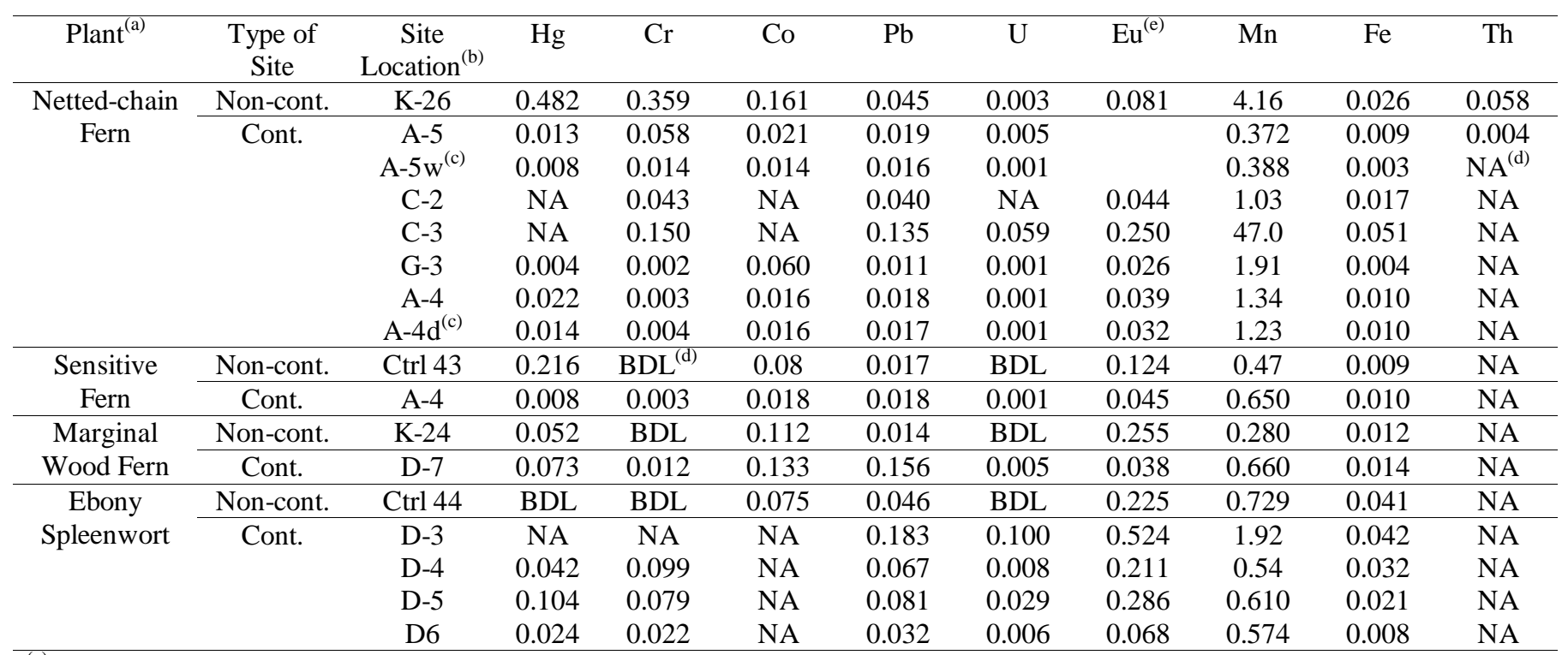

\footnotetext{
(a) Scientific names of plants presented in Appendix A; Samples collected on March 22, 2000.

(b) Site locations are presented in Figure 8.

(c) $\mathrm{W}=$ washed control, $\mathrm{d}=$ duplicate.

(d) NA = not available due to data not satisfying QA requirements. BDL = below detection limits.

(e) $\mathrm{Eu}$ is an analog for Ac.
} 

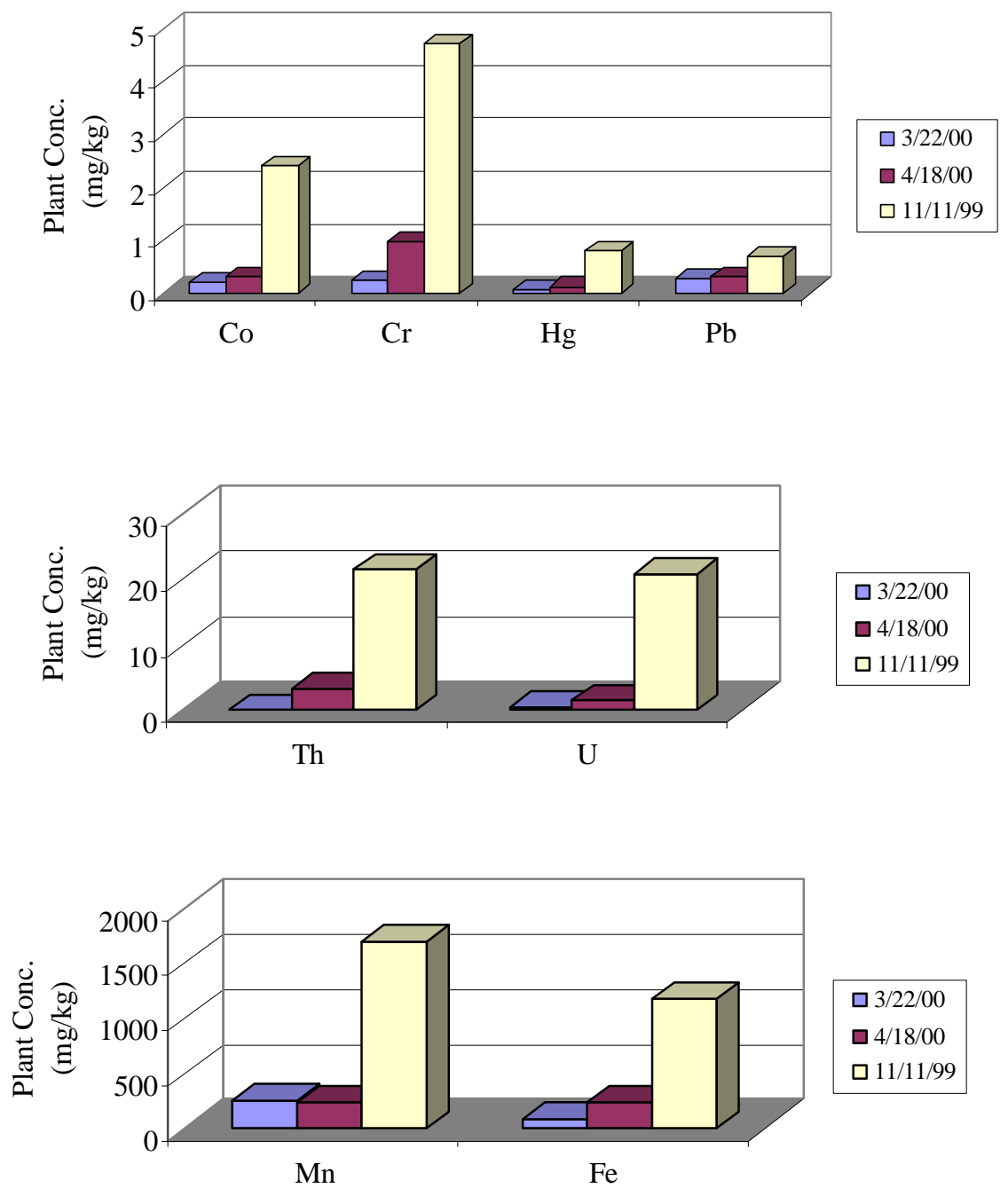

Figure 10. Elemental concentrations in netted-chain ferns as a function of harvesting date. 


\subsection{PLANT UPTAKE GREENHOUSE EXPERIMENT}

The objective of the Plant Uptake Greenhouse Experiment was to determine the proportion of COC that netted-chain fern (Woodwardia areolata) and Bermuda grass (Cynnodon dactylon) would take up from three TNX OD soils. Two of the soils were collected from the contaminated site (coordinates B-5 and C-5) and one soil was collected from a nearby noncontaminated area (referred to as the background soil). The netted-chain fern was selected in this test because a preliminary survey of plant uptake at the study site showed that this plant had relatively high concentration ratios. The Bermuda grass was selected as an example of a monocotyledon, which generally do not translocate metals from roots to the aboveground portion of the plant, and because its seeds were readily available. Bermuda grass would not be expected to grow well in wetlands. The Bermuda grass was grown under two fertilizer regimes, with and without $25-\mathrm{kg} / \mathrm{ha} 10-10-10$, N-P-K fertilizer. Fertilizer was included as a variable because it was anticipated that the Bermuda grass would not grow well in the TNX OD soils. The netted-chain fern was grown without adding fertilizer.

The B-5 contaminated soil (Table 22) had higher contamination levels than the C-5 soil (Table 23) for all COC except Hg. Perhaps more importantly, the background soil, collected 100-m south of the contamination site, contained rather high concentrations of $\mathrm{Cd}$ (3.4 $\mathrm{mg} / \mathrm{kg})$ and Co $(1.2 \mathrm{mg} / \mathrm{kg})$. These are pollutants because they exceed typical wetland background levels by more than an order of magnitude (Dixon et al. 1997). The netted-chain fern hyperaccumulated (had a total concentration ratio greater than unity) $\mathrm{Co}, \mathrm{Mn}$, and $\mathrm{Hg}$ from the background soil (Table 21), Co and Mn in the B-5 (Table 22) and C-5 (Table 23) soils. It had total concentration ratios between 0.1 and 1 for $\mathrm{Cr}, \mathrm{Cs}, \mathrm{Hg}$, and $\mathrm{U}$ when grown in the background soil, for $\mathrm{Cd}, \mathrm{Cr}, \mathrm{Cs}, \mathrm{Hg}, \mathrm{Pb}$, and $\mathrm{U}$ when grown in the $\mathrm{B}-5$ soil, and $\mathrm{Cd}$, $\mathrm{Cr}, \mathrm{Cs}, \mathrm{Fe}, \mathrm{Pb}, \mathrm{Th}$, and $\mathrm{U}$ when grown in the $\mathrm{C}-5$ soil. Stated differently, the netted-chain fern had a total concentration ratio greater than 0.1 for all COCs except $\mathrm{Hg}$ (in soil C-5) and Th (in B-5 and the background soils).

As anticipated, the Bermuda grass generally had appreciably lower total concentration ratios than the netted-chain fern when grown in the background soil (Table 24), the B-5 contaminated soil (Table 25), and the C-5 contaminated soil (Table 26). The netted-chain fern had total concentration ratios that were at least an order of magnitude greater those of the Bermuda grass for 14 of the 24 COCs (not including Fe and Mn). Compared to the Bermuda grass, the netted-chain fern was especially effective at taking up Co, Th, and $U$ and in two of the soils (background and B-5) for Hg. Only 3 of the 24 COC total concentration ratios of the Bermuda grass were greater than those of the netted-chain fern. The three total concentration ratios that were greater for the Bermuda grass were $\mathrm{Cs}$ and $\mathrm{Pb}$ in the background soil (Table 24) and Cs in the C-5 contaminated soil.

The addition of fertilizer to the soils supporting Bermuda grass slightly increased or had no effect on total concentration ratios (Table 21 and Table 23). In soil C-5, the addition of fertilizer increased the total concentration ratios of $\mathrm{Cs}$, Th, and $\mathrm{U}$, and in the background soil 
the fertilizer addition increased the concentration ratio for only Cs. The remaining concentration ratios were near identical, indicating that the results were reproducible.

Table 21. Greenhouse study of netted-chain fern in non-contaminated background soil: total soil (Soil-T) and available soil (Soil-A) COC concentrations $(\mathrm{mg} / \mathrm{kg})$, tissue concentrations $(\mathrm{mg} / \mathrm{kg})$, and concentration ratios (CR-T; plant conc./soil conc.).

\begin{tabular}{lccccc}
\hline & Soil-T & Soil-A & $\begin{array}{c}\text { Background Soil } \\
\text { Netted-chain } \\
\text { fern conc. }\end{array}$ & CR-T & CR-A \\
\cline { 2 - 5 } $\mathrm{Cd}$ & $3.4^{(\mathrm{a})}$ & $\mathrm{BDL}^{(\mathrm{b})}$ & 0.231 & 0.07 & $\mathrm{NA}$ \\
$\mathrm{Co}$ & 1.2 & 0.045 & 1.87 & 1.6 & 41.6 \\
$\mathrm{Cr}$ & 21.98 & 0.164 & 5.15 & 0.2 & 31.4 \\
$\mathrm{Cs}$ & 0.844 & 0.002 & 0.822 & 0.97 & 411.0 \\
$\mathrm{Fe}$ & 16470 & 173 & 293 & 0.02 & 1.7 \\
$\mathrm{Mn}$ & 127 & 9.6 & 2110 & 16.6 & 219.8 \\
$\mathrm{Hg}$ & 0.076 & $\mathrm{BDL}$ & 0.167 & 2.2 & $\mathrm{NA}$ \\
$\mathrm{Pb}$ & 4.5 & 0.35 & 1.27 & 0.28 & 3.6 \\
$\mathrm{Th}$ & 8.9 & 0.41 & 0.273 & 0.03 & 0.7 \\
$\mathrm{U}$ & 0.433 & 0.001 & 0.112 & 0.3 & 112.0 \\
\hline (a) Each result is the mean of four replicates; Netted-chain fern leaves were harvested after \\
six week of replanting. \\
(b) BDL $=$ below detection limit; NA = not available.
\end{tabular}


Table 22. Greenhouse study of netted-chain fern in contaminated B-5 soil: total soil (Soil-T) and available soil (Soil-A) COC concentrations $(\mathrm{mg} / \mathrm{kg}$ ), tissue concentrations $(\mathrm{mg} / \mathrm{kg})$, and concentration ratios (CR-T; plant conc./soil conc.).

\begin{tabular}{lccccc}
\hline & Soil-T & Soil-A & $\begin{array}{c}\text { Betted-chain } \\
\text { Fern Conc. }\end{array}$ & CR-T & CR-A \\
\cline { 2 - 6 } & 1.4 & BDL $^{(a)}$ & 0.223 & 0.2 & NA \\
$\mathrm{Cd}$ & 0.915 & 0.037 & 1.28 & 1.4 & 34.6 \\
$\mathrm{Cr}$ & 33.4 & 0.256 & 6.33 & 0.19 & 24.7 \\
$\mathrm{Cs}$ & 0.956 & 0.002 & 0.825 & 0.86 & 412.5 \\
$\mathrm{Fe}$ & 19954 & 186 & 909 & 0.05 & 4.9 \\
$\mathrm{Mn}$ & 36 & 4.3 & 1948 & 54 & 453.0 \\
$\mathrm{Hg}$ & 3.72 & $\mathrm{BDL}$ & 0.501 & 0.13 & $\mathrm{NA}$ \\
$\mathrm{Pb}$ & 10.9 & 0.9 & 2.11 & 0.19 & 2.34 \\
$\mathrm{Th}$ & 329 & 10.5 & 6.4 & 0.02 & 0.61 \\
$\mathrm{U}$ & 44 & 0.177 & 5.25 & 0.12 & 29.66 \\
\hline (a) & Each result is the mean of four replicates; netted-chain fern leaves were harvested after
\end{tabular}

${ }^{\text {(a) }}$ Each result is the mean of four replicates; netted-chain fern leaves were harvested after six week of replanting.

(b) $\mathrm{BDL}=$ below detection limit; $\mathrm{NA}=$ not available.

Table 23. Greenhouse study of netted-chain fern in contaminated C-5 soil: total soil (Soil-T) and available soil (Soil-A) COC concentrations $(\mathrm{mg} / \mathrm{kg}$ ), tissue concentrations $(\mathrm{mg} / \mathrm{kg})$, and concentration ratios (CR-T; plant conc./soil conc.).

\begin{tabular}{lccccc}
\hline & \multicolumn{5}{c}{ C-5 Soil } \\
\cline { 2 - 5 } & Soil-T & Soil-A & $\begin{array}{c}\text { Netted-chain } \\
\text { Fern Conc. }\end{array}$ & CR-T & CR-A \\
\hline $\mathrm{Cd}$ & $0.61^{(\mathrm{a})}$ & BDL $^{(\mathrm{b})}$ & 0.354 & 0.58 & $\mathrm{NA}$ \\
$\mathrm{Co}$ & 0.168 & 0.01 & 1.39 & 8.27 & 139.0 \\
$\mathrm{Cr}$ & 19.9 & 0.281 & 8.12 & 0.4 & 28.9 \\
$\mathrm{Cs}$ & 2.5 & 0.003 & 1.15 & 0.46 & 383.3 \\
$\mathrm{Fe}$ & 3332 & 32 & 545 & 0.16 & 17.0 \\
$\mathrm{Mn}$ & 17 & 5.3 & 1959 & 117 & 369.6 \\
$\mathrm{Hg}$ & 12.1 & 0.003 & 0.451 & 0.04 & 150.3 \\
$\mathrm{~Pb}$ & 2 & 0.29 & 1.58 & 0.79 & 5.4 \\
$\mathrm{Th}$ & 25 & 0.29 & 9.1 & 0.36 & 31.4 \\
$\mathrm{U}$ & 1.4 & 0.018 & 1.36 & 0.97 & 75.6 \\
\hline (a) & & & & &
\end{tabular}

${ }^{\text {(a) }}$ Each result is the mean of four replicates; netted-chain fern leaves were harvested after six week of replanting.

(b) $\mathrm{BDL}=$ below detection limit; $\mathrm{NA}=$ not available. 
WSRC-TR-2001-00032, REV. 0

Table 24. Greenhouse study of Bermuda grass in non-contaminated background soil: total soil (Soil-T) and available soil (Soil-A) COC concentrations $(\mathrm{mg} / \mathrm{kg})$, tissue concentrations $(\mathrm{mg} / \mathrm{kg})$, and concentration ratios (CR-T; plant conc./soil conc.).

\begin{tabular}{|c|c|c|c|c|c|c|c|c|c|c|}
\hline & \multicolumn{5}{|c|}{ No Fertilizer Added } & \multicolumn{5}{|c|}{ Fertilizer } \\
\hline & Soil-T & Soil-A & $\begin{array}{c}\text { Bermuda } \\
\text { Grass Conc. }\end{array}$ & CR-T & CR-A & Soil-T & Soil-A & $\begin{array}{c}\text { Bermuda } \\
\text { Grass Conc. }\end{array}$ & CR-T & CR-A \\
\hline $\mathrm{Cd}$ & $3.4^{(\mathrm{a})}$ & $\mathrm{BDL}^{(\mathrm{b})}$ & 0.172 & 0.051 & NA & 3.3 & NA & 0.181 & 0.055 & NA \\
\hline $\mathrm{Cr}$ & 21.98 & 0.164 & 5.22 & 0.237 & 31.8 & 21.56 & 0.142 & 5.1 & 0.237 & 35.9 \\
\hline Cs & 0.844 & 0.002 & 1.45 & 1.718 & 725.0 & 0.923 & 0.003 & 2.3 & 2.492 & 766.7 \\
\hline $\mathrm{Fe}$ & 16470 & 173 & 207 & 0.013 & 1.2 & 16493 & 185 & 225 & 0.014 & 1.2 \\
\hline $\mathrm{Hg}$ & 0.076 & BDL & 0.155 & 2.039 & NA & 0.082 & BDL & 0.18 & 2.195 & NA \\
\hline $\mathrm{Pb}$ & 4.5 & 0.35 & 2 & 0.444 & 5.7 & 4.35 & 0.41 & 2.1 & 0.483 & 5.1 \\
\hline Th & 8.9 & 0.41 & 0.132 & 0.015 & 0.3 & 7.9 & 0.46 & 0.182 & 0.023 & 0.4 \\
\hline $\mathrm{U}$ & 0.433 & 0.001 & 0.029 & 0.067 & 29.0 & 0.456 & 0.002 & 0.041 & 0.090 & 20.5 \\
\hline
\end{tabular}

(a) Each result is the mean of four replicates; Bermuda grass leaves were harvested after six week of replanting.

(b) $\mathrm{BDL}=$ below detection limit; $\mathrm{NA}=$ not available. 
WSRC-TR-2001-00032, REV. 0

Table 25. Greenhouse study of Bermuda grass in contaminated B-5 soil: total soil (Soil-T) and available soil (Soil-A) COC concentrations (mg/kg), tissue concentrations $(\mathrm{mg} / \mathrm{kg}$ ), and concentration ratios (CR-T; plant conc./soil conc.).

\begin{tabular}{lccccc}
\hline & \multicolumn{5}{c}{ Grass in B-5 Soil - No Added Fertilizer } \\
\cline { 2 - 6 } & Soil-T & Soil-A & $\begin{array}{c}\text { Bermuda } \\
\text { Grass Conc. }\end{array}$ & CR-T & CR-A \\
\hline $\mathrm{Cd}$ & $1.4^{(\mathrm{a})}$ & BDL $^{(\mathrm{b})}$ & 0.378 & 0.270 & $\mathrm{NA}$ \\
$\mathrm{Co}$ & 0.915 & 0.037 & 0.157 & 0.172 & 4.24 \\
$\mathrm{Cr}$ & 33.4 & 0.256 & 3.67 & 0.110 & 14.34 \\
$\mathrm{Cs}$ & 0.956 & 0.002 & 0.558 & 0.584 & 279 \\
$\mathrm{Fe}$ & 19954 & 186 & 66.1 & 0.003 & 0.36 \\
$\mathrm{Mn}$ & 36 & 4.3 & 264 & 7.333 & 61.40 \\
$\mathrm{Hg}$ & 3.72 & $\mathrm{BDL}$ & 0.066 & 0.018 & $\mathrm{NA}$ \\
$\mathrm{Pb}$ & 10.9 & 0.9 & 0.22 & 0.020 & 0.244 \\
$\mathrm{Th}$ & 329 & 10.5 & 0.13 & 0.000 & 0.012 \\
$\mathrm{U}$ & 44 & 0.177 & 0.035 & 0.001 & 0.198 \\
\hline (a) & &
\end{tabular}

(a) Each result is the mean of four replicates; Bermuda grass leaves were harvested after six week of replanting.

(b) $\mathrm{BDL}=$ below detection limit; $\mathrm{NA}=$ not available. 
WSRC-TR-2001-00032, REV. 0

Table 26. Greenhouse study of Bermuda grass in contaminated C-5: total soil (Soil-T) and available soil (Soil-A) COC concentrations $(\mathrm{mg} / \mathrm{kg})$, tissue concentrations $(\mathrm{mg} / \mathrm{kg})$, and concentration ratios (CR-T; plant conc./soil conc.).

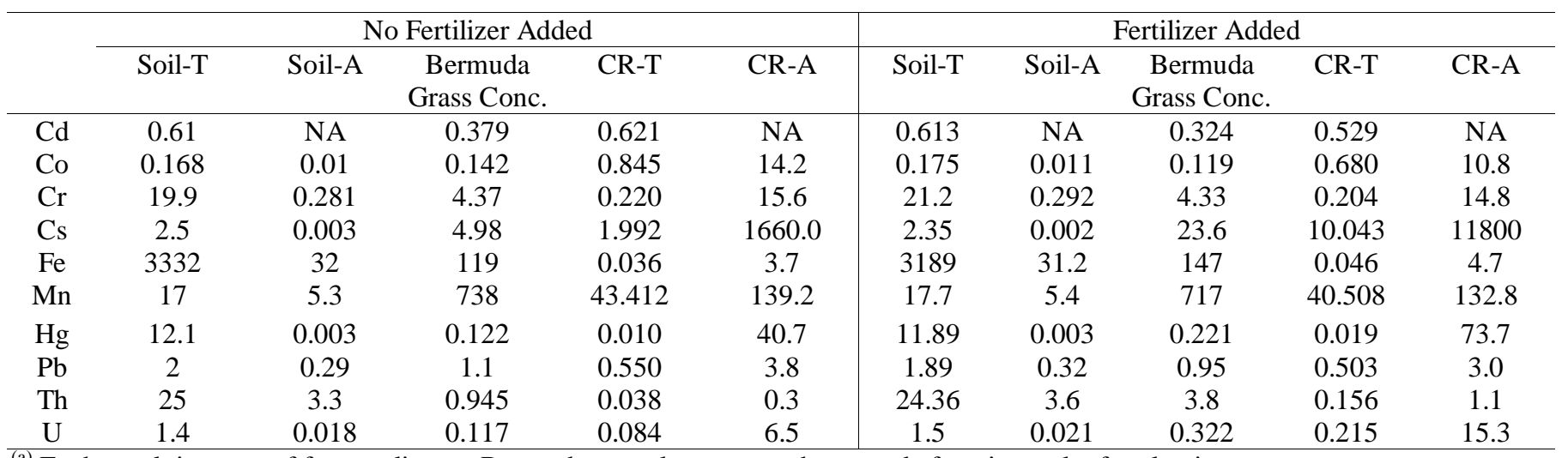

(a) Each result is mean of four replicates; Bermuda grass leaves were harvested after six week of replanting.

(b) $\mathrm{BDL}=$ below detection limit; $\mathrm{NA}=$ not available. 


\subsection{LEAF LEACHING EXPERIMENT}

The Leaf Leaching Experiment was set up and the samples were collected. No analytical data was collected prior to the termination of the study.

\subsection{GEOMAT EFFICIENCY LABORATORY EXPERIMENT}

In the second stage of phytoimmobilization, sequestration, contaminants from decomposed plant material would partition directly to a sequestering agent, or geomat. Geomats could be made from minerals, such as apatite and zeolite. Ground-up minerals can be placed inside of geotextile material (e.g., AMOCO Style 5412).

Among the potential sequestering agents tested, only metallic iron was effective at removing $\mathrm{Cr}$ (VI) from solution (Table 27). Metallic iron removes soluble $\mathrm{Cr}$ (VI) from solution by converting the soluble $\mathrm{Cr}$ (VI) species to the sparingly soluble $\mathrm{Cr}$ (III) species (Cantrell et al. 1995). Thus, the removal of Cr (VI) from solution is not via adsorption, instead, it is by reductive precipitation (Equation 1).

$$
\mathrm{CrO}_{4}{ }^{2-}+3 / 2 \mathrm{Fe}^{\mathrm{o}}+5 \mathrm{H}^{+}=\mathrm{Cr}(\mathrm{OH})_{3}+\mathrm{H}_{2} \mathrm{O}+3 / 2 \mathrm{Fe}^{2+}
$$

Mixtures of metallic iron with other sequestering agents were evaluated because it is likely that more than one material will be required to sequester all eight contaminants. The addition of North Carolina apatite, hydroxyapatite, and clinoptilolite (a type of zeolite) greatly decreased the $\mathrm{Cr}(\mathrm{VI})$-removal effectiveness of the metallic iron.

The $\mathrm{pH}$ of the equilibrium solutions at the end of the contact time between the sequestering agents and the aqueous $\mathrm{Cr}(\mathrm{VI})$ did not vary greatly between treatments. As expected, the $\mathrm{pH}$ of the metallic iron, $\mathrm{Fe}(0)$, treatment increased. This can be attributed to the metallic iron reducing water, thereby creating hydroxides as shown in Equation 2.

$$
\mathrm{Fe}^{0}+\mathrm{H}_{2} \mathrm{O}=\mathrm{Fe}^{2+}+\mathrm{OH}^{-}+1 / 2 \mathrm{H}_{2 \text { (gas) }}
$$


Table 27. Chromium distribution coefficients $(\mathrm{Kd})$ for several sequestering agents in a SRS surface water.

\begin{tabular}{lccc}
\hline Treatment & Avg. $\mathrm{pH}$ & $\begin{array}{r}\text { Avg. Equilibrium } \\
\text { Cr(VI) Conc. (mg/L) }\end{array}$ & $\begin{array}{c}\mathrm{Kd} \\
\text { (mL/g) }\end{array}$ \\
\hline SRS Blank Control & 4.6 & 0.02 & -- \\
Cr Spike Control & 4.4 & 1.00 & -- \\
$\mathrm{Fe}(0)$ & 5.8 & 0.26 & $294 \pm 8$ \\
$\mathrm{Fe}(0)$ / NC Apatite & 5.7 & 0.46 & $66 \pm 25$ \\
$\mathrm{Fe}(0)$ / Hydroxyapatite & 5.3 & 0.67 & $26 \pm 4$ \\
$\mathrm{Fe}(0)$ / Clinoptilolite & 5.2 & 0.63 & $11 \pm 1$ \\
$\mathrm{Fe}(0)$ / NC-Apatite / Clinoptilolite & 5.3 & 0.78 & $10 \pm 2$ \\
$\mathrm{Fe}(0)$ / Hydroxyapatite / Clinoptilolite & 5.2 & 0.68 & $17 \pm 0$ \\
\hline (a) 0.3 g solid: 30-mL SRS surface water; 1-wk equilibration period; 3 replicates; total \\
mass of mixtures = 0.3 g evenly divided between sequestering agents.
\end{tabular}

Evaluation of $\mathrm{Hg}$ sequestering agents was conducted in uncontaminated SRS surface water containing $6 \mathrm{mg} / \mathrm{L}$ total organic carbon, and a leaf litter leachate containing $>100 \mathrm{mg} / \mathrm{L}$ total organic carbon. The Kd values in the presence of soluble organic matter tended to be lower than when the organic matter was not present (Table 28). This is likely the result of the organic matter forming a complex with the $\mathrm{Hg}$, and the soluble $\mathrm{Hg}$-organic matter complex sorbing less strongly than the uncomplexed $\mathrm{Hg}$ to the sequestering agents. Thus, it appears the presence of the strongly complexing organic ligands present in plant leachate moderately decrease the removal effectiveness of these sequestering materials.

Pyrite had a Kd value of $\sim 20,000 \mathrm{~mL} / \mathrm{g}$ and metallic iron had a Kd value of $>1000 \mathrm{~mL} / \mathrm{g}$ (Table 28). The reduction in soluble $\mathrm{Hg}$ concentrations in pyrite $\left(\mathrm{FeS}_{2}\right)$ treated solutions is not surprising because the pyrite can release sulfides, which can then combine with $\mathrm{Hg}$ (II) to form the sparingly soluble mercury-sulfide precipitate, cinnabar, $\mathrm{HgS}$ (Bodek et al. 1988). The relatively low $\mathrm{Kd}$ for the gypsum $\left(\mathrm{CaSO}_{4}\right)$ may be attributed to the fact that the test suspension was oxic, therefore the sulfate in the gypsum was never reduced to sulfide, the form of sulfur that forms the sparingly soluble mercury precipitate. In a soil system where microbes are present and where reducing conditions exist, it is very likely that the sequestering ability of gypsum will improve. Thus, evaluation of gypsum for this application needs to be conducted under conditions more similar to those of its final application, namely in the presence of reducing soils that will convert the sulfate to sulfide.

The more positive the oxidation-reduction potential (or redox), the more oxidized the system is; conversely the more negative the redox potential, the more reduced the system is. At $\mathrm{pH}$ 5 , the approximate $\mathrm{pH}$ of the TNX OD soils, the expected redox range is between 50 (reduced) and $650 \mathrm{mV}$ (oxidized). In the metallic iron system, the $\mathrm{pH}$ rose to 10.2 and the redox dropped to $110 \mathrm{mV}$ (Table 28). The rather large metallic-iron reduction potential is appreciably larger than expected; values of $\sim 200 \mathrm{mV}$ are common. Faust and Osman (1981) 
reported similar reductions in soluble $\mathrm{Hg}$ concentrations in experimental systems when $\mathrm{pH}$ values increased and $\mathrm{Eh}$ values decreased. As described above, the elevated $\mathrm{pH}$ in the metallic iron system can be attributed to water molecules being reduced to hydrogen gas and hydroxide ions. The low $\mathrm{pH}$ of the pyrite addition can be attributed to the oxidation of pyrite, which is a well-known acidifying process that is widespread at coal mining sites.

Table 28. Effect of sequestering materials on aqueous $\mathrm{Hg}$ concentration. ${ }^{\text {(a) }}$

\begin{tabular}{|c|c|c|c|c|c|c|c|c|}
\hline \multirow[t]{2}{*}{ Treatment } & \multicolumn{4}{|c|}{ 6-mg/L Total Organic Carbon } & \multicolumn{4}{|c|}{ >100-mg/L Total Organic Carbon } \\
\hline & $\begin{array}{l}\text { Avg. } \\
\mathrm{pH}\end{array}$ & $\begin{array}{l}\text { Avg. } \\
\text { Eh } \\
(\mathrm{mV})\end{array}$ & $\begin{array}{c}\text { Avg. } \\
\mathrm{Hg} \\
(\mathrm{mg} / \mathrm{L})\end{array}$ & $\begin{array}{c}\mathrm{Kd} \\
(\mathrm{mL} / \mathrm{g})^{(\mathrm{b})}\end{array}$ & $\begin{array}{l}\text { Avg. } \\
\mathrm{pH}\end{array}$ & $\begin{array}{l}\text { Avg. } \\
\text { Eh } \\
(\mathrm{mV})\end{array}$ & $\begin{array}{c}\text { Avg. } \\
\mathrm{Hg} \\
(\mathrm{mg} / \mathrm{L})\end{array}$ & $\underset{(\mathrm{mL} / \mathrm{g})^{(\mathrm{b})}}{ }$ \\
\hline Blank Control & 5.8 & 409 & 0.000 & -- & 5.0 & 290 & 0.001 & -- \\
\hline Hg Spike Control & 3.1 & 498 & 1.865 & -- & 4.7 & 311 & 0.630 & -- \\
\hline Gypsum Addition & 3.3 & 510 & 1.582 & $17 \pm 0$ & 4.5 & 330 & 0.344 & $448 \pm 56$ \\
\hline Pyrite Addition & 3.0 & 345 & 0.002 & $108838 \pm 26457$ & 4.3 & 361 & 0.009 & $20259 \pm 413$ \\
\hline Metallic iron Addition & 10.2 & 100 & 0.029 & $6270 \pm 719$ & 5.8 & 110 & 0.127 & $1364 \pm 117$ \\
\hline
\end{tabular}

In the third experiment, six elements were added to the solution at concentrations of approximately $50 \mu \mathrm{g} / \mathrm{L}$. After one week the concentrations of each tested element were significantly reduced by almost all the amendments (Table 29). Hydroxylapatite and North Carolina apatite were the most effective at reducing $\mathrm{Eu}, \mathrm{Pb}$, and $\mathrm{U}$ concentrations in the solutions and $\mathrm{K}_{\mathrm{d}}$ values in these treatments were very high (Table 29). Other researchers also reported the high effectiveness of apatite in remediation of $\mathrm{Pb}$ or $\mathrm{U}$ contaminated soils through a precipitation mechanism (Knox et al. 2000). Both zeolites were effective for most elements, however, not for uranium. Metallic iron and $\mathrm{Fe}$ oxide $\left(\mathrm{Fe}-\mathrm{rich}^{\mathrm{TM}}\right.$, waste byproduct) removed the greatest mass of the targeted constituents from solution. The metallic iron could be attractive as a geomat material because it was effective in immobilizing $\mathrm{Cr}, \mathrm{Hg}, \mathrm{Co}, \mathrm{Ba}, \mathrm{Eu}, \mathrm{Pb}$ and $\mathrm{U}$; however, one problem with metallic iron is that it has a limited life span before it oxidizes, rusts, and looses its reductive capacity. Thus, if metallic iron was to be included in a geomat, then the material would have to be removed before the metallic iron completely rusted. 
Table 29. $\mathrm{Kd}$ values $(\mathrm{mL} / \mathrm{g})$ of $\mathrm{Co}, \mathrm{Ba}, \mathrm{Eu}, \mathrm{Pb}$, and $\mathrm{U}$ for various potential sequestering agent materials. $^{\text {(a) }}$

\begin{tabular}{lccccc}
\hline Treatment & $\mathrm{Co}$ & $\mathrm{Ba}^{(\mathrm{b})}$ & $\mathrm{Eu}^{(\mathrm{b})}$ & $\mathrm{Pb}$ & $\mathrm{U}$ \\
\hline Hydroxylapatite & 7683 & 421 & 725426 & 138607 & 282448 \\
North Carolina Apatite & 470 & 222 & 313157 & 214916 & 264829 \\
Zeolite (Clinoptilolite) & 4114 & 6217 & 14473 & 1805864 & 7 \\
Zeolite (Phillipsite) & 223 & 6222 & 819 & 24828 & 9 \\
Fe oxide (waste by product) & 23037 & 3688 & 2561951 & 363449 & 8479 \\
Metallic Fe & 259629 & 26076 & 1525058 & 18108 & 452210 \\
\hline (a) 0.3 g solid: 30-mL SRS surface water; 1-wk equilibration period; 3 replicates; total mass \\
of mixtures = 0.3 g evenly divided between sequestering agent. \\
(b) Ba and Eu are used as analogs for Ra and Ac geochemical behavior.
\end{tabular}

\subsection{GEOMAT EFFICIENCY FIELD EXPERIMENT}

The first part of this project, setting up in the field, was completed. Chemical analytical results were not completed prior to the termination of the project.

\subsection{MODELING PHYTOIMMOBILIZATION}

\subsubsection{Abbreviated Mass-Balance Model}

Mass-balance calculations were conducted with available data using equations 3 - 8 .

$$
\begin{gathered}
\mathrm{I}_{\text {current soil }}=\mathrm{A}_{\text {current soil }} \times \rho_{\text {soil bulk }} \times 1 \mathrm{e} 6\left(\mathrm{~cm}^{3} / \mathrm{m}^{3}\right) \times 1 \mathrm{e}-12(\mathrm{Ci} / \mathrm{pCi}) \times \mathrm{V}_{\text {site }} \\
\mathrm{A}_{\text {plant } i}=\mathrm{A}_{\text {current soil }} \times \mathrm{CR}_{\text {plant } i} \\
\mathrm{I}_{\text {plant } i}=\mathrm{A}_{\text {plant } i} \times 1000 \mathrm{~g} / \mathrm{kg} \times \mathrm{M}_{\text {plant } i} \times 1 \mathrm{e}-4 \mathrm{ha} / \mathrm{m}^{3} \times \mathrm{A}_{\text {site }} 1 \mathrm{e}-12 \mathrm{pCi} / \mathrm{Ci} \\
\mathrm{ACR}_{\text {plant } i}==\mathrm{I}_{\text {plant } i} / \mathrm{I}_{\text {soil }} \times 100 \\
\mathrm{ACR}_{\text {total }}=\mathrm{ACR}_{\text {fern }}+\mathrm{ACR}_{\text {leaf litter }} \\
\mathrm{I}_{\text {soil } j}=\mathrm{I}_{\text {soil } j-1}-\left(\mathrm{I}_{\text {soil } j-1} \times \mathrm{ACR}_{\text {total }}\right)
\end{gathered}
$$

$\mathrm{I}_{\text {current soil }}=$ current soil inventory $(\mathrm{Ci})$

$\mathrm{A}_{\text {current soil }}=$ current soil activity $(\mathrm{pCi} / \mathrm{g})$

$\rho_{\text {soil bulk }}=$ soil bulk density $\left(\mathrm{g} / \mathrm{cm}^{3}\right)$

$\mathrm{V}_{\text {site }}=$ contamination site volume $\left(\mathrm{m}^{3}\right)$

$\mathrm{A}_{\text {plant } i}=$ fern or leaf litter activity $(\mathrm{pCi} / \mathrm{g})$ 
$\mathrm{CR}_{\text {plant } i}=$ concentration ratio of fern or leaf litter $([\mathrm{pCi} / \mathrm{g}$ plant $] /[\mathrm{pCi} / \mathrm{g}$ soil $])$

$\mathrm{I}_{\text {plant } i}=$ fern or leaf litter inventory $(\mathrm{Ci} / \mathrm{yr})$

$\mathbf{M}_{\text {plant } i}=$ fern or leaf litter annual biomass $(\mathrm{kg} / \mathrm{ha} \cdot \mathrm{yr})$

$\mathrm{A}_{\text {site }}=$ contaminated site area $\left(\mathrm{m}^{2}\right)$

$\mathrm{ACR}_{\text {plant } i}=$ annual contaminant reduction in soil due to fern or leaf litter uptake (\%)

$\mathrm{ACR}_{\text {total }}=$ annual contaminant reduction in soil due to fern and leaf litter uptake (\%)

$\mathrm{I}_{\mathrm{soil} j}=$ soil contaminant inventory for year $j$

$\mathrm{I}_{\text {soil } j-1}=$ soil contaminant inventory for the year before year $j$

The calculations using Equations 3 - 8 and the input values used in the calculations are presented in Appendix C. For the purposes of these calculations, the following assumptions were made.

- The site targeted for clean up was $152.4-\mathrm{m} \times 91.44-\mathrm{m} \times 0.305-\mathrm{m}(500-\mathrm{ft}$ x $300-\mathrm{ft}$ $\mathrm{x} 1-\mathrm{ft})$, or $4214-\mathrm{m}^{3}\left(150,000-\mathrm{ft}^{3}\right)$. It should be noted that the area selected for clean up does not influence the calculated duration required to achieve a targeted clean up level.

- The site had to be cleaned to $10 \mathrm{e}-6$ risk level. The actual risk level has not been determined yet, but this is a low (conservative) level. For instance, the risk for an industrial worker is $10 \mathrm{e}-3$.

- Soil COC activity did not decrease with time in a linear manner. Instead it decreased at a slower rate as the COC concentrations in the soil decreased. The reason for this is that it is expected that plant uptake efficiency will decrease as the soil COC concentrations in the soil decrease. This is an important assumption which attempts to avoid the common error made in the 1980's regarding remediation predictions, which assumed that short term kinetic studies conducted at high contaminant concentrations were applicable when the COC concentrations in the system decreased.

- The geomat was $100 \%$ efficient at removing contaminants from the mobile aqueous phase. Since the Kd values for many of the COC's were $>10,000 \mathrm{~mL} / \mathrm{g}$, this simplifying assumption does not greatly compromise the otherwise conservative nature of this calculation (Section 4.5).

- There is no radiological decay. This is an important assumption because the concentration of Th-232 affects the concentration of the other radionuclides, i.e., Th-232 (half-life $=1.4 \times 10^{10} \mathrm{yr}$ ) decays to Ra-228 (half-life $=6.7 \mathrm{yr}$ ), Ac-228 (half-life $=6.1 \mathrm{hr}$ ), Th-228 (half-life $=1.9 \mathrm{yr}$ ), and Pb-212 (half-life $=10.6 \mathrm{hr}$ ). Since Th-232 has an appreciably longer half-life than its daughters, the daughters will come to secular equilibrium with Th-232. Therefore, so long as the Th-232 is present, there will be a continued source of the daughters.

- No COC losses outside of the 4214- $\mathrm{m}^{3}$ zone of interest, i.e., no over-land and subsurface migration of COCs in the aqueous and colloidal phases.

- The average COC soil concentrations were equal to the Medium Specific Exposure Point Concentrations (WSRC 1999).

- The threshold values are those provided by Karen Connor (see email transmittal in Appendix B). 
The change in the annual soil concentrations ( $\mathrm{I}_{\text {soil } j}$; Equation 8 ) of Ra-228, Pb-212, Th-228, U-235, U-238 and Ac-228 are presented in the following five figures. Additionally, a summary of the number of years required for the technology to be in place in order to achieve the desired reduction in COC concentrations is presented in Table 30. Based on these calculations, Th-232, Th-234, and U-233 already exist at levels well below the 10e-6 risk level and therefore should not be included in the list of COCs (Table 30). The only isotope that could be remediated by this technology was Ra-228. Ra-228 activity decreased below the $10 \mathrm{e}-6$ risk level after 52 -yr of phytoimmobilization. The remaining contaminants, $\mathrm{Pb}-212$, Th-228, U-235, and U-238 required more than 300-yr of remediation before $10 \mathrm{e}-6$ risk levels were obtained.

Since it has not been established that the TNX OD site must be cleaned to a 10e-6 risk level, additional calculations were conducted to determine the length of time it would take to clean the site to 10e-5 risk levels (Table 30). Based on these calculations, Th-232, Th-234, U-233, $\mathrm{U}-235, \mathrm{~Pb}-212$, and $\mathrm{Ra}-228$ already exist at levels below the $10 \mathrm{e}-6$ risk level. Thus, only U238 and Th-228 would require remediation. Based on these calculations, U-238 could be cleaned with phytoimmobilization within 9-yr, whereas Th-228 would not be clean within 300-yr.

Another set of analyses was conducted using higher biomass estimates. The netted-chain fern biomass (928 kg/ha·yr) and leaf litter biomass (7389 kg/ha·yr) used in the baseline calculations (Figure 11 through Figure 16) were quite conservative. Increasing biomass could be easily accomplished by adopting common forestry practices, such as thinning trees, planting trees with higher annual leaf biomass (and COC concentration ratios, such as tupelo), and fertilizing. For these additional calculations, the biomass for the fern was set to $4643 \mathrm{~kg} / \mathrm{ha} \cdot \mathrm{yr}$ and for the leaf litter was set to $14,778 \mathrm{~kg} / \mathrm{ha} \cdot \mathrm{yr}$. The new biomass for the fern was calculated based on a greater plant density estimate (from $65 \%$ to $75 \%$ cover) and a greater plant mass estimate (from 20 to $60 \mathrm{~g} /$ plant). The new leaf litter biomass value is twice that of the conservative value; the forestry practices listed above can typically increase virgin forest biomass on the Savannah River Site two or three fold (personal communication with Dr. John Blake, U.S. Forestry Service, Aiken, SC).

Based on the higher biomass values, the phytoimmobilization technology would clean three of the five COCs to 10e-6 risk levels (Table 30). Pb-212, Ra-228, and U-235 would be cleaned to $10 \mathrm{e}-6$ risk levels within 183,20 , and 298 years, respectively. Th-228 and U-238 would not be cleaned within 300 years of phytoimmobilization. As mentioned above, Th232, Th-234, and U-233 already exist at levels that do not require remediation. 
WSRC-TR-2001-00032, REV. 0

Table 30. Current soil inventory ( $\mathrm{I}_{\text {current soil }}$; Equation 3 ), allowable soil inventory, annual contaminant reduction in the soil (ACR total$_{\text {; }}$ Equation 7) and the number of years necessary to accomplish clean up to $10 \mathrm{e}-6$ risk levels.

\begin{tabular}{lcccccc}
\hline Isotope & $\begin{array}{c}\text { Current Soil } \\
\text { Inventory } \\
(\mathrm{Ci})\end{array}$ & $\begin{array}{c}\text { Allowable Soil } \\
\text { Inventory (Ci) }\end{array}$ & $\begin{array}{c}\text { Annual } \\
\text { Reduction } \\
(\%)\end{array}$ & $\begin{array}{c}\text { Years to Accomplish } \\
\text { Clean up to 10e-6 } \\
\text { Risk Levels }\end{array}$ & $\begin{array}{c}\text { Years to Accomplish } \\
\text { Clean up to 10e-5 } \\
\text { Risk Levels }\end{array}$ & $\begin{array}{c}\text { Years to Accomplish Clean up to } \\
\text { 10e-6 Risk Levels Using Larger, } \\
\text { Likely Achievable, Annual Biomass } \\
\text { Values }\end{array}$ \\
\hline Ac-228 & 0.03274 & NA & 0.00301 & NA & NA & NA \\
Pb-212 & 0.03388 & 0.02851 & 0.00035 & $>300$ & 0 & 183 \\
Ra-228 & 0.09165 & 0.01116 & 0.04096 & 52 & 0 & 0 \\
Th-232 & 0.15044 & 3.78527 & 0.00024 & 0 & $>300$ & $>300$ \\
Th-228 & 0.1359 & 0.01003 & 0.00024 & $>300$ & 0 & 0 \\
Th-234 & 1.06825 & 1.77983 & 0.00024 & 0 & 0 & 298 \\
U-235 & 0.05518 & 0.03202 & 0.00047 & $>300$ & 0 & 0 \\
U-233 & 1.21995 & 2.76375 & 0.00047 & 0 & 9 & $>300$ \\
U-238 & 1.20731 & 0.12283 & 0.00047 & $>300$ & 0 & 0 \\
\hline
\end{tabular}




\section{Ra-228}

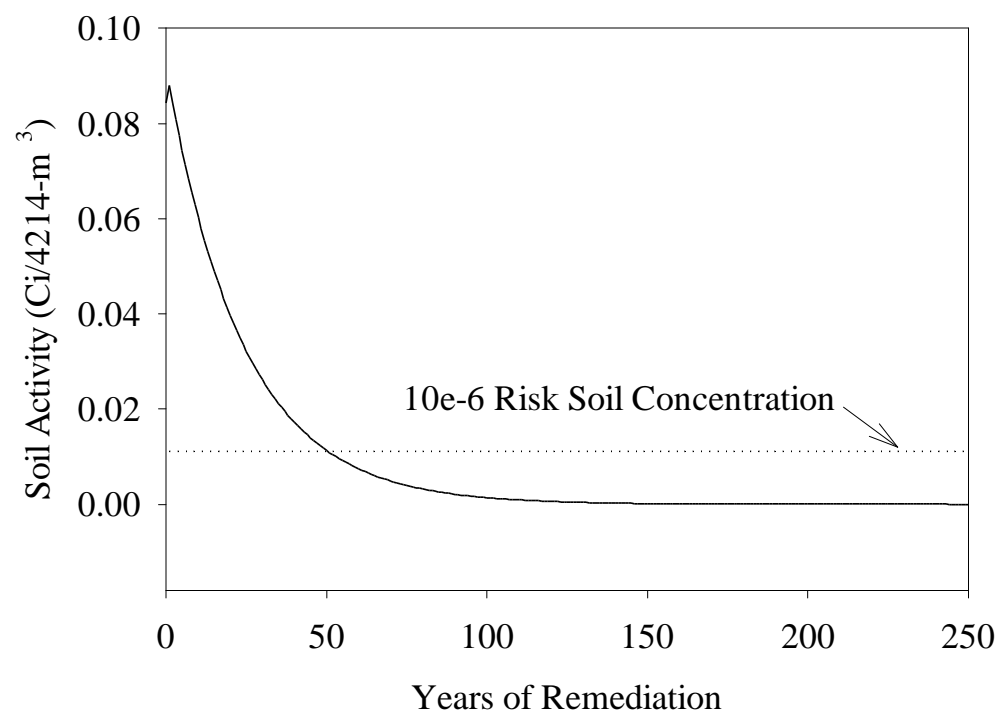

Figure 11. Predicted soil Ra-228 activity as a function of years of phytoimmobilization remediation at the TNX OD site (volume of remediated soil $=4214 \mathrm{~m}^{3}$; target $10 \mathrm{e}-6$ risk clean up level indicated with dotted line). 


\section{$\mathrm{Pb}-212$}

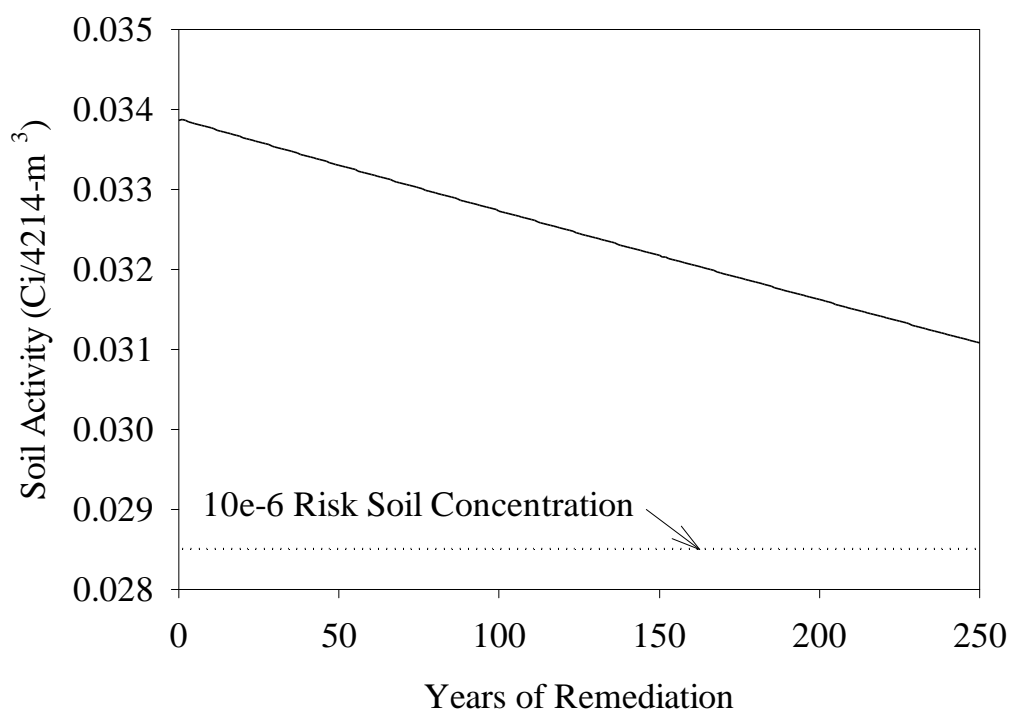

Figure 12. Predicted soil $\mathrm{Pb}-212$ activity as a function of years of phytoimmobilization remediation at the TNX OD site (volume of remediated soil $=4214 \mathrm{~m}^{3}$; target $10 \mathrm{e}-6$ risk clean up level indicated with dotted line). 


\section{Th-228}

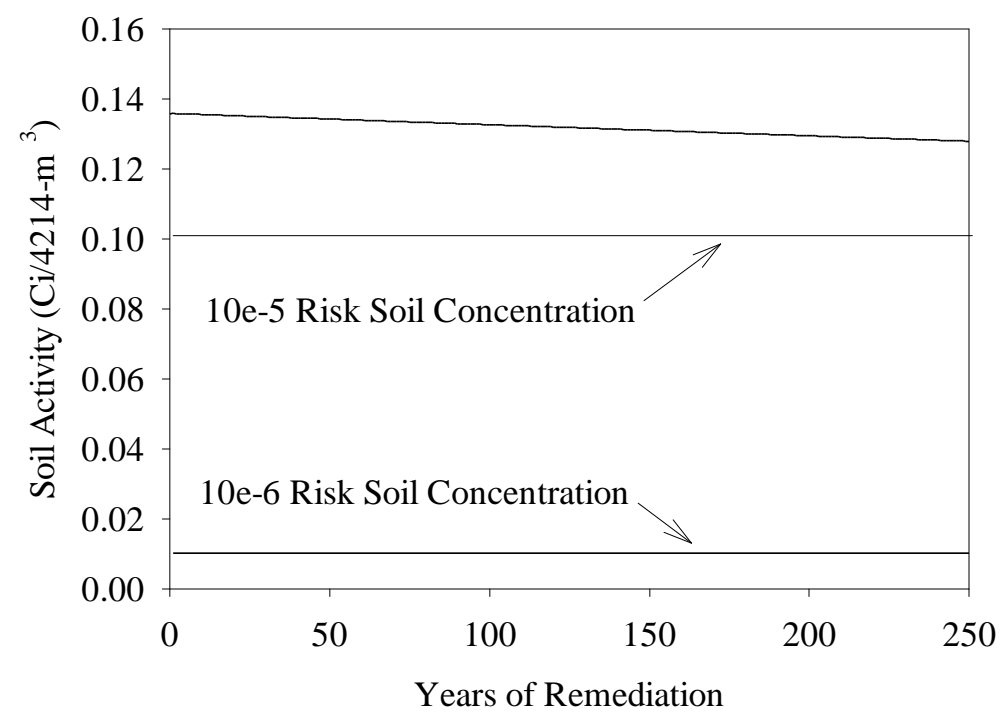

Figure 13. Predicted soil Th-228 activity as a function of years of phytoimmobilization remediation at the TNX OD site (volume of remediated soil $=4214 \mathrm{~m}^{3}$; target $10 \mathrm{e}-6$ risk clean up level indicated with dotted line). 


\section{U-235}

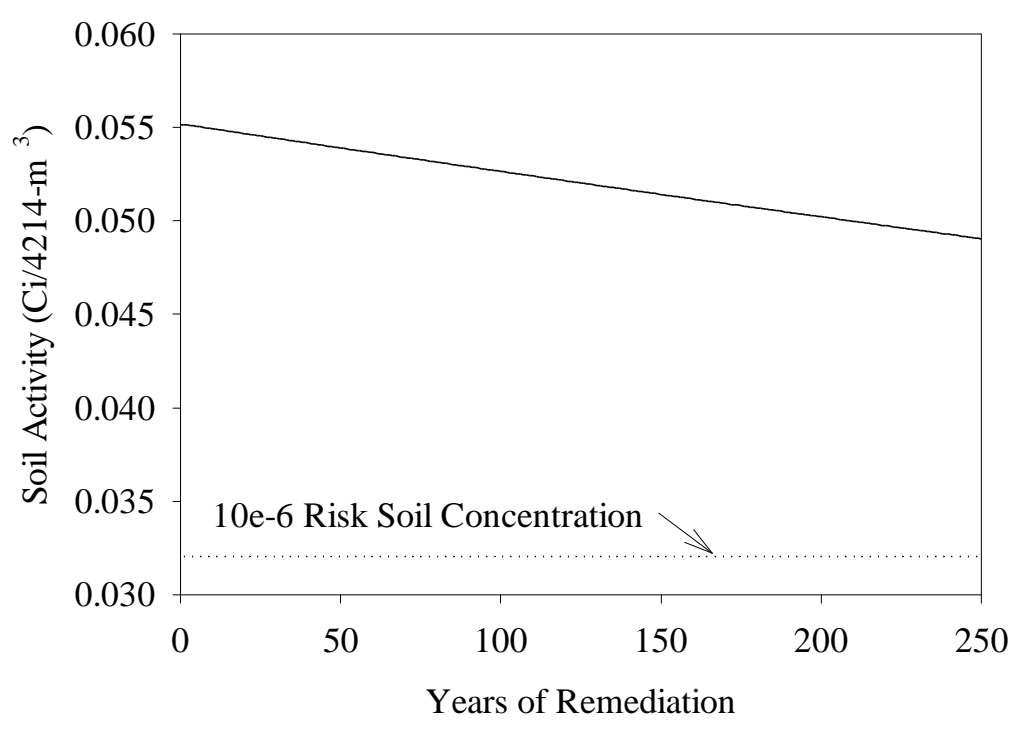

Figure 14. Predicted soil U-235 activity as a function of years of phytoimmobilization remediation at the TNX OD site (volume of remediated soil $=4214 \mathrm{~m}^{3}$; target $10 \mathrm{e}-6$ risk clean up level indicated with dotted line). 


\section{U-238}

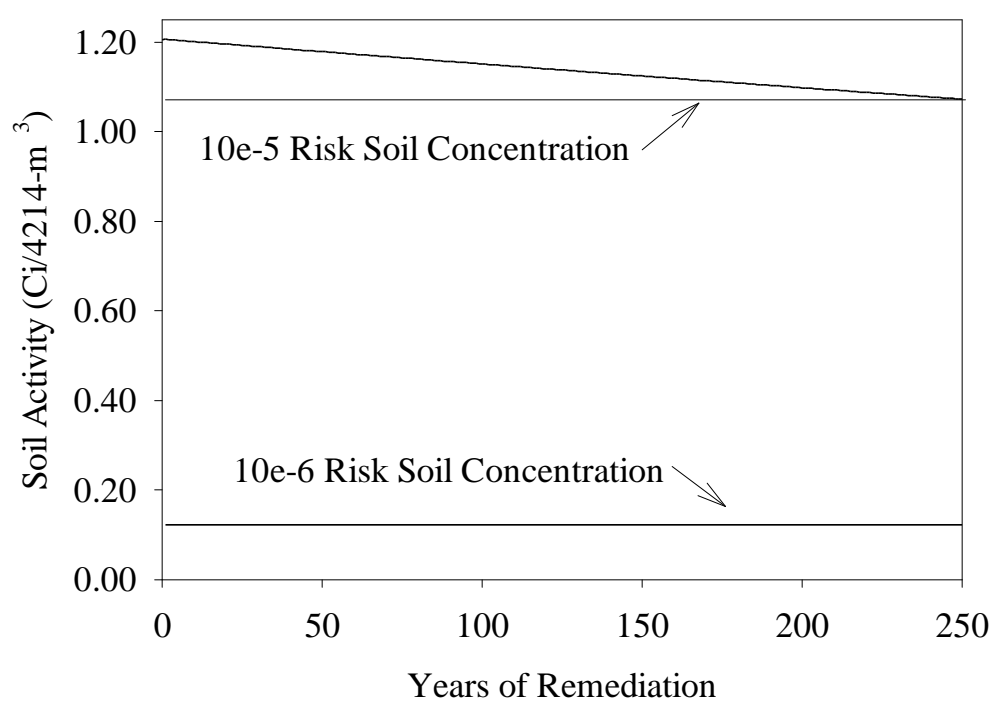

Figure 15. Predicted soil U-238 activity as a function of years of phytoimmobilization remediation at the TNX OD site (volume of remediated soil $=4214 \mathrm{~m}^{3}$; target $10 \mathrm{e}-6$ risk clean up level indicated with dotted line). 
Ac-228

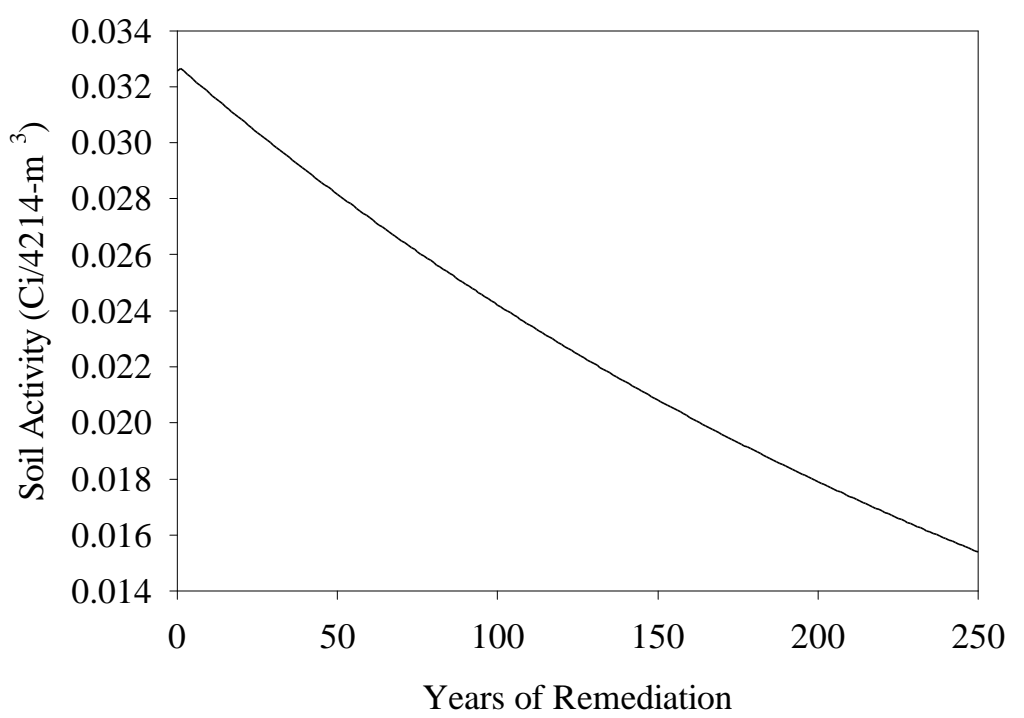

Figure 16. Predicted soil Ac-228 activity as a function of years of phytoimmobilization remediation at the TNX OD site (volume of remediated soil $=4214 \mathrm{~m}^{3}$; target $10 \mathrm{e}-6$ risk clean up level was not calculated). 


\subsubsection{Linear-Kinetic Reservoir Model}

The linear-kinetic reservoir model was not used to evaluate the effectiveness of the phytoimmobilization technology because the project was terminated prior to collecting the needed data. A description of the model is presented in the status report (Kaplan et al. 2000a) and the available input values are described below.

Briefly, the linear-kinetic reservoir approach of Lasaga (1980) evaluates the time-dependant cycling of contaminants using a matrix algebra solution of a series of competing transfer reactions between contaminant reservoirs. The mass of contaminant, reaction pathway (i.e., the reservoirs to which contaminant can be transferred), and the rate that contaminants are transferred between reservoirs determine the distribution between each of the reservoirs.

The laboratory and field studies were designed to provide model input data for this analysis. In our model conceptualization the reservoirs considered are the root-zone soil, bulk soil (below root zone), vegetation, and the reactive geomat. A general model schematic is shown in Figure 17 and the data collected in this study are designed to provide the mass of contaminant in each reservoir and the rate of transfer between the reservoirs as designated by the arrow. The matrix solution of Lasaga (1980) can then be used to calcuate the distribution of contaminants between each of the reservoirs as a fuction of time.

In preparation for the modeling, input values for the model was assembled based on available data (Table 31 and Table 32). In assembling this data, a number of decisions had to be made. For the sequestering agent, it was decided that metallic iron would not be used, even though it had high Kd values. The reason for this decision was that if the metallic iron were used, it would have to be removed at a rather frequent basis because of its tendency to rust, thereby changing into a poorer sequestering agent. Consequently, the geomat that was selected consisted of a hydroxyapatite, clinoptilolite, and pyrite. 


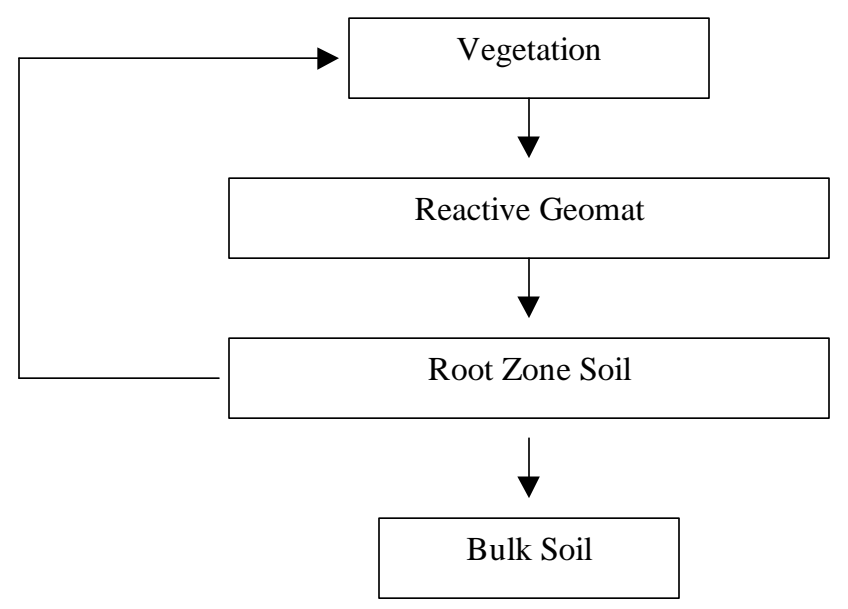

Figure 17. Linear-kinetic Reservoir Model of Phytoimmobilization at the TNX OD Site.

One concern is that instead of using the measured $\mathrm{Kd}$ values for $\mathrm{Hg}, \mathrm{Pb}$, $\mathrm{Th}$, and $\mathrm{U}$, perhaps solubility values should be used. The sequestering agents are removing these contaminants by forming the sparingly soluble phases of $\mathrm{Hg}-\mathrm{S}, \mathrm{Pb}-\mathrm{PO} 4, \mathrm{ThO}_{2}$ or $\mathrm{Th}-\mathrm{PO}_{4}$, and $\mathrm{U}_{-} \mathrm{PO}_{4}$. The implications of using a solubility versus a sorption construct is that the contaminant solution concentration will remain constant for as long as the solid source material exists. Once the solid phase controlling solubility is totally dissolved, the contaminant concentration drops to zero. With the sorption, or $\mathrm{K}_{\mathrm{d}}$, construct the contaminant solution concentration varies directly with the concentration in the solid phase. The contaminant concentration in the Kd construct slowly decreases, all the time maintaining a fixed ratio of contaminant concentration on the solid phase to the liquid phase.

The proposed input data also lists the highest soil concentration measured in the TNX OD. This "conservatism" may not be necessary; perhaps a better choice for soil concentration values would be to pick the contaminant concentration from a single site, such as the most contaminated site near coordinate A-5. No one site has the highest concentrations of all contaminants. 
WSRC-TR-2001-00032, REV. 0

Table 31. Preliminary input values for the Linear-kinetic Reservoir Model of Phytoimmobilization (additional input in next table).

\begin{tabular}{|c|c|c|c|}
\hline $\begin{array}{l}\text { Parameter } \\
\text { Category }\end{array}$ & Parameter & Values & Comments \\
\hline \multirow{2}{*}{$\begin{array}{l}\text { Annual } \\
\text { Biomass }\end{array}$} & Leaf Litter & $7389 \mathrm{~kg} / \mathrm{ha} / \mathrm{yr}$ & Based on litter collected in \& beneath baskets; baskets put out in middle of fall. Control sites only. \\
\hline & Fern & $928 \mathrm{~kg} / \mathrm{ha} / \mathrm{yr}$ & Assumptions: $17 \mathrm{~g} / \mathrm{plant}$ (actual is 10 to $25 \mathrm{~g} / \mathrm{plant}$ ); $1.5 \mathrm{ft} 2 /$ plant, $50 \%$ cover \\
\hline \multirow[t]{8}{*}{ Geomat Kd's } & Ac-Kd & $725426 \mathrm{~mL} / \mathrm{g}$ & Hydroxyapatite/Clinoptilolite/Sulfur no OM data, Used Eu as nonrad analog in experiments \\
\hline & Co-Kd & $7683 \mathrm{~mL} / \mathrm{g}$ & Hydroxyapatite/Clinoptilolite/Sulfur no OM data. \\
\hline & $\mathrm{Cr}-\mathrm{Kd}$ & $15 \mathrm{~mL} / \mathrm{g}$ & Hydroxyapatite/Clinoptilolite/Sulfur. If we add $\mathrm{Fe}(0)$ the Geomat $\mathrm{Kd}$ greatly increases to $200 \mathrm{~mL} / \mathrm{g}$. \\
\hline & $\mathrm{Hg}-\mathrm{Kd}$ & $20259 \mathrm{~mL} / \mathrm{g}$ & Pyrite/Leaf Leachate data (Prague 2000); Acidifying nature of pyrite may adversely affect plant growth. \\
\hline & $\mathrm{Pb}-\mathrm{Kd}$ & $138607 \mathrm{~mL} / \mathrm{g}$ & Hydroxyapatite/Clinoptilolite/Sulfur no OM data \\
\hline & Ra-Kd & $6217 \mathrm{~mL} / \mathrm{g}$ & Hydroxyapatite/Clinoptilolite/Sulfur no OM data, Used Ba as nonrad analog in experiments \\
\hline & Th-Kd & $5700 \mathrm{~mL} / \mathrm{g}$ & Actually $>5700 \mathrm{~mL} / \mathrm{g}$, Hydroxyapatite/Clino/Sulfur no OM data, detection limitation \\
\hline & $\mathrm{U}-\mathrm{Kd}$ & $282448 \mathrm{~mL} / \mathrm{g}$ & Hydroxyapatite/Clinoptilolite/Sulfur no OM data \\
\hline \multirow[t]{8}{*}{ Soil Kds } & Ac-Kd & $255 \mathrm{~mL} / \mathrm{g}$ & Conservative Kd from desorption Kd of site specific sediment, WSRC-TR-99-00490 Table 16, Ce as analog \\
\hline & $\mathrm{Co}-\mathrm{Kd}$ & $255 \mathrm{~mL} / \mathrm{g}$ & Conservative Kd from desorption Kd of site specific sediment, WSRC-TR-99-00488 Table 16, Ni as analog \\
\hline & $\mathrm{Cr}-\mathrm{Kd}$ & $58 \mathrm{~mL} / \mathrm{g}$ & Conservative Kd from desorption Kd of site specific sediment, WSRC-TR-99-00494 Table 16 \\
\hline & $\mathrm{Hg}-\mathrm{Kd}$ & $4704 \mathrm{~mL} / \mathrm{g}$ & Conservative Kd from desorption Kd of site specific sediment, WSRC-TR-99-00494 Table 16 \\
\hline & $\mathrm{Pb}-\mathrm{Kd}$ & $11460 \mathrm{~mL} / \mathrm{g}$ & Conservative Kd from desorption Kd of site specific sediment, WSRC-TR-99-00494 Table 16 \\
\hline & Ra-Kd & $336 \mathrm{~mL} / \mathrm{g}$ & Conservative Kd from desorption Kd of site specific sediment, WSRC-TR-99-00489 Table 16, Ba as analog \\
\hline & Th-Kd & $115 \mathrm{~mL} / \mathrm{g}$ & Conservative Kd from desorption Kd of site specific sediment, WSRC-TR-99-00494 Table 16 \\
\hline & $\mathrm{U}-\mathrm{Kd}$ & $170 \mathrm{~mL} / \mathrm{g}$ & Conservative Kd from desorption Kd of site specific sediment, WSRC-TR-99-00494 Table 16 \\
\hline \multirow[t]{10}{*}{ Soil Conc. } & Ac-228 & $101 \mathrm{pCi} / \mathrm{g}$ & Conservative, Selected greatest Total Concentration (acid digest) from maps in WSRC-RP-4158, Rev. 0 \\
\hline & Co-60 & ??? $\quad \mathrm{pCi} / \mathrm{g}$ & \\
\hline & $\mathrm{Cr}$ & $156 \mathrm{mg} / \mathrm{kg}$ & Conservative, Selected greatest Total Concentration (acid digest) from maps in WSRC-RP-4158, Rev. 0 \\
\hline & $\mathrm{Hg}$ & $30.8 \mathrm{mg} / \mathrm{kg}$ & Conservative, Selected greatest Total Concentration (acid digest) from maps in WSRC-RP-4158, Rev. 0 \\
\hline & $\mathrm{Pb}-212$ & $97.1 \mathrm{pCi} / \mathrm{g}$ & Conservative, Selected greatest Total Concentration (acid digest) from maps in WSRC-RP-4158, Rev. 0 \\
\hline & Ra-228 & $106 \mathrm{pCi} / \mathrm{g}$ & Conservative, Selected greatest Total Concentration (acid digest) from maps in WSRC-RP-4158, Rev. 0 \\
\hline & Th-232 & $52.5 \mathrm{pCi} / \mathrm{g}$ & Conservative, Selected greatest Total Concentration (acid digest) from maps in WSRC-RP-4158, Rev. 0 \\
\hline & Th-232 & $694 \mathrm{mg} / \mathrm{L}$ & Conservative, Selected greatest Total Conc. (acid digest) from 6 sed.; WSRC-TR-99-00488 Tables 14/15 \\
\hline & $\mathrm{U}-238$ & $559 \mathrm{mg} / \mathrm{kg}$ & Conservative, Selected greatest Total Conc. (acid digest) from 6 sed.; WSRC-TR-99-00488 Tables 14/15 \\
\hline & $\mathrm{U}-238$ & $123 \mathrm{pCi} / \mathrm{g}$ & Conservative, Selected greatest Total Concentration (acid digest) from maps in WSRC-RP-4158, Rev. 0 \\
\hline
\end{tabular}


WSRC-TR-2001-00032, REV. 0

Table 32. Preliminary input values for the Linear-kinetic Reservoir Model of Phytoimmobilization (additional input in previous table).

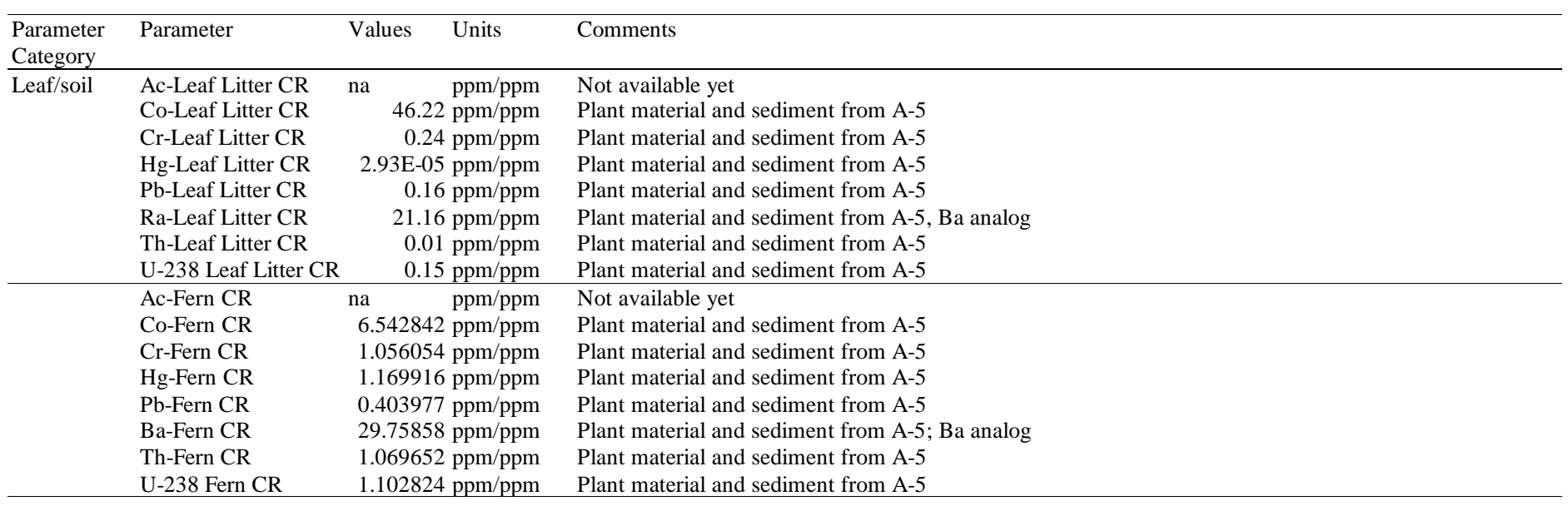




\subsection{CONCLUSIONS}

In the status report associated with this project (Kaplan et al. 2000a), it was concluded that it may be possible to implement phytoimmobilization at the TNX OD operable unit. The manner in which phytoimmobilization would be deployed is to use both the natural leaf litter, which generates a lot of biomass with moderate levels of contaminants, and to plant ferns to mine the contaminants near the soil surface, where the contaminants are most concentrated. The geomat would be made by placing a combination of hydroxyapatite, clinoptilolite, and a sulfide mineral between two layers of geotextile material. The geomat would then be placed in pieces around existing trees.

A mass balance calculation was conducted with the available site-specific data to provide an early estimate of the efficacy of the proposed phytoimmobilization scheme. In these calculations, it was assumed that the amount of contaminant remediated would decrease over time, thereby diminishing the error of extrapolating long-term estimates based on short-term experimental results. Based on these conservative estimates, Th-232, Th-234, and U-233 already exist at levels well below the 10e- 6 risk level and therefore do not require remediation. The remaining risk drivers at the site are $\mathrm{Ra}-228, \mathrm{~Pb}-212$, Th-228, U-235, and $\mathrm{U}-238$. Ra-228 could be cleaned up to below 10e-6 risk levels within 52-years; Pb-212, Th228 , U-235, and U-238 would require $>300$-years. Another set of calculations was conducted using increased, readily achievable, biomass input values. In addition to cleaning up Ra-228, these calculations indicated that $\mathrm{Pb}-212$ and $\mathrm{U}-235$ could be cleaned up to $10 \mathrm{e}-6$ risk levels within 183 and 298 years, respectively. Th-228 and U-238 would not be cleaned within 300-years of phytoimmobilization. A final set of calculations was conducted using a lower clean up requirement based on a $10 \mathrm{e}-5$ risk level. The risk levels upon which clean up levels are based have not been established yet, but a risk level of 10e-5 is very probable in light of the fact that an industrial worker, one of the possible risk receptors, has a risk level of 10e-3. All the contaminants included in the 10e-5 risk-level calculations, expect Th-228, could be clean with phytoimmobilization within 10 years or did not require remediation.

There are very few remediation options for ecologically sensitive wetland areas. Application of phytoimmobilization at the TNX OD site has a number of attributes, but also an important limitation, namely that it will likely not clean up the site of all radionuclides. Among its attributes, phytoimmobilization uses existing natural biogeocycling processes and simply interrupts these processes by accumulating the contaminants in the geomat. Additionally, it should greatly reduce the cost of waste disposal by creating a concentrated waste in the sequestering agent. However, the fact that not all the contaminants will be cleaned in a timely manner compromises its utility, thereby requiring that we further evaluate other remediation approaches and/or the clean up goals of the site. 


\subsection{REFERENCES}

Adriano, D. C. Trace Elements in the Terrestrial Environment. Springer-Verlag, Inc., New York (1986).

Bodek, W.J. Lymn, W.F. Reehel, D.H. Rosenblott, B.I. Walton, R.A. Conway, Environmental Inorganic Chemistry: Properties, Processes, and Estimation Methods, New York, Pergamon Press, (1988).

Cantrell, K. J., and D. I. Kaplan. "Sorptive Barriers for Groundwater Remediation.” pp. 4663 - 4677. In Robert A. Meyers (ed.), Encyclopedia of Environmental Analysis and Remediation, John Wiley \& Sons, Inc., New York (1998).

Cantrell, K. J., D.I. Kaplan, D.I., T. W. Wietsma, "Zero-valent Iron for the in Situ Remediation of Selected Metals in Groundwater." J. Hazardous Materials. 42, p. 201 (1995).

Cunningham, S. D., and D. W. Ow. "Promises and Prospects of Phytoremediation." Plant Physiol. 110, p 715 (1996).

Dixon, K. L., V. A. Rogers, S. P. Conner, D. L. Cummings, J. B. Gladden, and J. M. Weber. Geochemical and Physical Properties of Wetland Soils at the Savannah River Site. Westinghouse Savannah River Company, Aiken, SC (1997).

Faust, S. D. In: Chemistry of Natural Waters, Ann Arbor Science Publishers, Inc., (1981).

Hiraga, Y., M. Kurokawa, J. R. Guo, and T. Suga. "Ion-transport Activity of Phenylpentanoic acids Occurring in the Roots of Athyrium yokoscense." Bioscience Biotechnology and Biochemistry 63, p 958 (1999).

Ichihaski, H., H. Morita, and R. Tatsukawa. "Rare-earth elements (rees) in Naturally Grown Plants in Relation to Their Variation in Soils." Environmental Plooution 75, p 157 (1992).

Kaplan, D. I. Sampling and Analyses Plan for the Phytostabilization Study at the TNX Outfall Delta, Lower Discharge Gully and Swamp Operable Unit. WSRC-RP-99-01078. Westinghouse Savannah River Company, Aiken SC (1999).

Kaplan, D. I., A. S. Knox, T. G. Hinton, and S. M. Serkiz. Proof-of-Concept of the Phytoimmobilizaotn Technology for TNX Outfall Delta: Status Report. WSRC-TR-2000-

00375, Rev. 0. Westinghouse Savannah River Company, Aiken, SC (2000a).

Kaplan, D. I., S. V. Mattigod, K. E. Parker, and G. Iversen. I-129 Test and Research to Support Disposal Decisions. WSRC-TR-2000-00283, Rev. 0, Westinghouse Savannah River Company, Aiken, SC (2000b). 
Kaplan, D. I., and S. M. Serkiz. In-situ Kd Values and Geochemical Behavior for Inorganic and Organic Constituents of Concern at the TNX Outfall Delta. WSRC-TR-99-00488.

Westinghouse Savannah River Company, Aiken, SC (1999).

Knox, A. S, J.C. Seaman, M.J. Mench, J. Vangronsveld, 2000, Remediation of Metal- and Radionuclide-Contaminated Soils by In Situ Stabilization In: Environmental Restoration of Metals Contaminated Soils, Ed. IK Iskandar, CRC Press, Boca Raton, FL. (2000).

Lasaga, A. C. 1980. "The Kinetic Treatment of Geochemical Cycles.” Geochimica et Cosmochimica Acta. 44, p 815 (1980).

Lindsay, W. L.., and W. A. Norvell. “Development of a DTPA Soil Test for Zinc, Iron, Manganese, and Copper.” Soil Science Society of America Journal. 42, p 421 (1978).

Ma, L. Q., K. M. Komar, C. Tu, W. Zharng, Y. Cai, and E. D. Kennelley. "Discovery of an Efficacious Arsenic Hyperaccumulating Fern Plant." Nature. (in press) (2000).

Mengel, K. and E. A. Kirkby. Principles of Plant Nutrition. International Potash Institute, Berne, Switzerland (1978).

Morishita, R., and J. K. Boratynski. "Accumulation of Cadmium and Other Metals in Organs of Plants Growing Around Metal Smelters in Japan.” Soil Science and Plant Nutrition 38, p 781 (1992).

Neite, H., N. Neikes, and R. Wittig. "Distribution of Heavy-Metals in the Root area and in Organs of Herbaceous Plants in Beech Forests.” Flora 185, p 325 (1991).

Nishizono, H., H. Ichikawa, S. Suziki, and F. Ishii. "The Role of the Root Cell-wall in the Heavy-metal Tolerance of Athyrium yokoscense." Plant and Soil 101, p 15 (1987).

Nishizono, H., H. Minemura, S. Suzuki, and F. Ishii. “An Inducible Copper-thiolate Complex in the Fern, Athyrium yokoscense - Involvement in Copper-Tolerance of the Fern." Plant and Cell Physiology 29, p. 1345 (1988).

Nishizono, H., S. Suzuki, and F. Ishii. “Accumulation of Heavy-metals in the Metal-tolerant fern, Athyrium yokoscense, Growing on Environments.” Plant and Soil 102, p 65 (1987).

Nishizono, H., T. Watanabe, T. Orii, and S. Suzuki. "Suppression of Inhibitory Effects of Copper on Enzymatic-activities by Copper-binding Substances from Athyrium yokoscense assayed in vitro." Plant and Cell Physiology 30 p 565 (1989).

Ozaki, T., S. Enomoto, Y. Minai, S. ambe, F. Ambe, and Y. Makide. "Beneficial Effect of Rare Earth Elements on the Growth of Dryopteris erythrosora." Journal of Plant Physiology 156 p 330 (2000). 
WSRC-TR-2001-00032, REV. 0

WSRC. RFI/RI with BRA for the TNX Outfall Delta, Lower Discharge Gully and Swamp Operable Unit. WSRC-RP-98-4158, Rev. 0. Westinghouse Savannah River Company, Aiken, SC (1999). 
WSRC-TR-2001-00032, REV. 0

7.0 APPENDIX A: ADDITIONAL DATA

Page 83 
Table 33. Scientific names of several plants referred to in this report.

\begin{tabular}{ll}
\hline Common Name & Scientific Name \\
\hline Water Oak & Quercus nigra L. \\
Swamp Tupelo & Nyssa sylvatica var. biflora (Walt.) Sarg. \\
Bald Cypress & Taxodium distichum (L.) L.C. Rich \\
Loblolly Pine & Pinus taeda L. \\
Red Maple & Acer rubrum L. \\
Sweetgum & Liquidambar styraciflua L. \\
American Sycamore & Platanus occidentalis L. \\
Netted Chain Fern & Woodwardia areloata (L.) Moore \\
Sensitive Fern & Onoclea sensibilis L. \\
Marginal Wood Fern & Drypteris marginals (L.) Gray \\
Ebony Spleenwort & Asplenium platynneuron (L.) Oakes \\
Switchcane & Arundinaria gigantea (Walt.) Muhl. \\
Bermuda Grass & Cynnodon dactylon (L.) \\
\hline
\end{tabular}


WSRC-TR-2001-00032, REV. 0

Table 34. Available soil (Soil-A) and plant concentrations (mg/kg; dry weight) and available concentration ratios (CR; plant conc./available soil conc.).

\begin{tabular}{|c|c|c|c|c|c|c|c|c|c|c|c|c|c|}
\hline & $\begin{array}{c}\text { Site } \\
\text { Location }^{(a)}\end{array}$ & \multicolumn{3}{|c|}{$\mathrm{Co}$} & \multicolumn{3}{|c|}{$\mathrm{Cr}$} & \multicolumn{3}{|c|}{$\mathrm{Hg}^{(\mathrm{b})}$} & \multicolumn{3}{|c|}{ Th } \\
\hline Tupelo $^{(\mathrm{c})}$ & A5 & 0.12 & 19.2 & 160 & 0.07 & 0.43 & 6.1 & & 0.01 & & 20.3 & 10.3 & 0.507 \\
\hline \multirow{3}{*}{$\begin{array}{l}\text { Sweet- } \\
\text { gum }\end{array}$} & A5 & 0.12 & 0.74 & 6.17 & 0.07 & 0.65 & 9.3 & & 0.03 & & 20.3 & 4.7 & 0.232 \\
\hline & D3 & 0.06 & 0.47 & 8 & 0.13 & 0.78 & 6.0 & & 0.04 & & 1.5 & 6.8 & 4.533 \\
\hline & B4 & 0.09 & 0.37 & 4.11 & 0.15 & 0.61 & 4.1 & & 0.02 & & 11 & 4.7 & 0.427 \\
\hline \multirow[t]{2}{*}{ Water Oak } & A5 & 0.12 & 0.34 & 2.83 & 0.07 & 0.35 & 5.0 & & 0.06 & & 20.3 & 1.5 & 0.074 \\
\hline & B3 & 0.41 & 0.76 & 1.85 & 0.14 & 0.35 & 2.5 & & 0.06 & & 14.6 & 1.3 & 0.089 \\
\hline Loblolly & A5 & 0.12 & 0.45 & 3.75 & 0.07 & 0.41 & 5.9 & & 0.02 & & 20.3 & 0.13 & 0.006 \\
\hline Pine & $\mathrm{C} 5$ & 0.01 & 0.16 & 16.00 & 0.28 & 0.7 & 2.5 & & 0.02 & & 3.3 & 0.24 & 0.072 \\
\hline Leaf Litter & $\mathrm{C} 5$ & 0.01 & 0.24 & 24.00 & 0.28 & 1.24 & 4.4 & & 0.07 & & 3.3 & 0.7 & 0.212 \\
\hline \multirow[t]{2}{*}{ Fern $^{(\mathrm{d})}$} & C3 & 0.02 & 0.23 & 11.50 & 0.14 & 0.71 & 5.1 & & 0.07 & & 1.4 & 0.02 & 0.014 \\
\hline & B5 & 0.41 & 0.31 & 0.76 & 0.26 & 0.65 & 2.5 & & 0.09 & & 10.5 & 2.7 & 0.257 \\
\hline
\end{tabular}

\footnotetext{
(a) For site location see Figure 8 .

(b) No total or available $\mathrm{Hg}$ is reported because this set of data did not satisfy QA requirements.

(c) Leaf samples were collected between November 9, 1999 and March 15, 2000.

(d) Netted chain fern sample collected March 22, 2000.
} 
WSRC-TR-2001-00032, REV. 0

Table 34 (Continuation). Available soil (Soil-A) and plant concentrations (mg/kg; dry weight) and concentration ratios (CR-A; plant conc./available soil conc.).

\begin{tabular}{|c|c|c|c|c|c|c|c|c|c|c|c|c|c|}
\hline \multirow{2}{*}{$\begin{array}{l}\text { Plant } \\
\text { Species }\end{array}$} & \multirow{2}{*}{$\begin{array}{c}\text { Site } \\
\text { Location } \\
\text { (a) }\end{array}$} & \multicolumn{3}{|c|}{$\mathrm{Ba}$} & \multicolumn{3}{|c|}{$\mathrm{Ce}$} & \multicolumn{3}{|c|}{$\mathrm{Pb}$} & \multicolumn{3}{|c|}{$\mathrm{Mn}$} \\
\hline & & Soil-A & Plant & CR-A & Soil-A & Plant & CR-A & Soil-A & Plant & CR-A & Soil-A & Plant & CR-A \\
\hline \multirow[t]{2}{*}{ Tupelo $^{(b)}$} & A5 & 0.12 & 324 & 2700 & 0.1 & 0.43 & 4.3 & 0.01 & 1 & 100.0 & 15.2 & 1712 & 113 \\
\hline & B3 & 1.51 & 169 & 112 & 4.12 & 0.3 & 0.1 & 0.19 & 0.42 & 2.2 & 3.3 & 1144 & 347 \\
\hline \multirow{3}{*}{$\begin{array}{l}\text { Sweet- } \\
\text { gum }\end{array}$} & A5 & 0.12 & 183 & 1525 & 0.1 & 1.4 & 14.0 & 0.01 & 0.95 & 95.0 & 15.2 & 1805 & 119 \\
\hline & D3 & 0.43 & 188 & 437 & 1.01 & 0.83 & 0.8 & 0.36 & 0.62 & 1.7 & 17.2 & 2268 & 132 \\
\hline & B4 & 2.13 & 72 & 34 & 0.06 & 0.64 & 10.7 & 0.01 & 0.35 & 35.0 & 6.1 & 1253 & 205 \\
\hline \multirow[t]{2}{*}{ Red Maple } & C5 & 0.2 & 46 & 230 & 0.23 & 1.11 & 4.8 & 0.29 & 1.2 & 4.1 & 5.3 & 1077 & 203 \\
\hline & B3 & 1.51 & 97 & 64 & 4.12 & 0.7 & 0.2 & 0.19 & 0.7 & 3.7 & 3.3 & 580 & 176 \\
\hline \multirow[t]{2}{*}{ Water Oak } & A5 & 0.12 & 130 & 1083 & 0.1 & 1.5 & 15.0 & 0.01 & 0.62 & 62.0 & 15.2 & 2726 & 179 \\
\hline & B3 & 1.51 & 129 & 85 & 4.12 & 0.98 & 0.2 & 0.19 & 0.31 & 1.6 & 3.3 & 2161 & 655 \\
\hline Loblolly & A5 & 0.12 & 15 & 125 & 0.1 & 0.44 & 4.4 & 0.01 & 0.56 & 56.0 & 15.2 & 969 & 64 \\
\hline Pine & $\mathrm{C} 5$ & 0.2 & 8 & 40 & 0.23 & 1.07 & 4.7 & 0.29 & 0.78 & 2.7 & 5.3 & 308 & 58 \\
\hline \multirow[t]{3}{*}{ Leaf Litter } & C5 & 0.2 & 78 & 390 & 0.23 & 1.11 & 4.8 & 0.29 & 1.2 & 4.1 & 5.3 & 651 & 123 \\
\hline & B5 & 0.37 & 58 & 157 & 1.05 & 0.53 & 0.5 & 0.9 & 0.83 & 0.9 & 4.3 & 582 & 135 \\
\hline & B3 & 1.51 & 106 & 70 & 4.12 & 0.57 & 0.1 & 0.19 & 0.69 & 3.6 & 3.3 & 745 & 226 \\
\hline Netted & A5 & 0.12 & 95 & 792 & 0.1 & 4.9 & 49.0 & 0.01 & 0.32 & 32.0 & 15.2 & 246 & 16 \\
\hline Chain & $\mathrm{C} 2$ & 0.45 & 70 & 156 & 4.94 & 3.7 & 0.7 & 1.71 & 0.18 & 0.1 & 7.5 & 85 & 11 \\
\hline \multirow[t]{2}{*}{ Fern ${ }^{(\mathrm{c})}$} & $\mathrm{C} 3$ & 0.15 & 84 & 560 & 0.17 & 2.4 & 14.1 & 0.26 & 0.22 & 0.8 & 0.5 & 313 & 626 \\
\hline & B5 & 0.37 & 67 & 181 & 1.05 & 3.8 & 3.6 & 0.9 & 0.23 & 0.3 & 4.3 & 226 & 53 \\
\hline
\end{tabular}

(a) Leaf samples were collected between November 9, 1999 and March 15, 2000.

(b) For site location see Figure 8.

(c) Netted chain fern sample collected March 22, 2000. 
WSRC-TR-2001-00032, REV. 0

Table 34 (Continuation). Available soil (Soil-A) and plant concentrations (mg/kg; dry weight) and concentration ratios (CR-A; plant conc./available soil conc.).

\begin{tabular}{|c|c|c|c|c|c|c|c|}
\hline \multirow{2}{*}{$\begin{array}{l}\text { Plant } \\
\text { Species }\end{array}$} & \multirow{2}{*}{$\begin{array}{c}\text { Site } \\
\text { Location }^{(a)}\end{array}$} & \multicolumn{3}{|c|}{$\mathrm{U}$} & \multicolumn{3}{|c|}{$\mathrm{Fe}$} \\
\hline & & Soil-A & Plant & CR-A & Soil-A & Plant & CR-A \\
\hline \multirow[t]{2}{*}{ Tupelo $^{(b)}$} & A5 & 0.07 & 2.4 & 34.3 & 74 & 145 & 2.0 \\
\hline & B3 & 0.503 & 8.9 & 17.7 & 55 & 131 & 2.4 \\
\hline \multirow[t]{3}{*}{ Sweet-gum } & A5 & 0.07 & 1.7 & 24.3 & 74 & 138 & 1.9 \\
\hline & D3 & 0.11 & 17 & 154.5 & 55.2 & 214 & 3.9 \\
\hline & B4 & 0.19 & 7 & 36.8 & 74.4 & 177 & 2.4 \\
\hline \multirow[t]{2}{*}{ Red Maple } & C5 & 0.018 & 8.1 & 450.0 & 32 & 179 & 5.6 \\
\hline & B3 & 0.503 & 1.1 & 2.2 & 55 & 258 & 4.7 \\
\hline \multirow[t]{2}{*}{ Water Oak } & A5 & 0.07 & 0.1 & 1.4 & 74 & 183 & 2.5 \\
\hline & B3 & 0.503 & 0.05 & 0.1 & 55 & 159 & 2.9 \\
\hline Loblolly & A5 & 0.07 & 0.11 & 1.6 & 74 & 69 & 0.9 \\
\hline Pine & $\mathrm{C} 5$ & 0.018 & 0.81 & 45.0 & 32 & 79 & 2.5 \\
\hline \multirow[t]{3}{*}{ Leaf Litter } & $\mathrm{C} 5$ & 0.018 & 2 & 111.1 & 32 & 216 & 6.8 \\
\hline & B5 & 0.177 & 1.2 & 6.8 & 186 & 186 & 1.0 \\
\hline & B3 & 0.503 & 3.7 & 7.4 & 55 & 177 & 3.2 \\
\hline Netted & A5 & 0.07 & 1.42 & 20.3 & 74 & 239 & 3.2 \\
\hline Chain & $\mathrm{C} 2$ & 0.933 & 0.25 & 0.3 & 75 & 98 & 1.3 \\
\hline \multirow[t]{2}{*}{ Fern $^{(\mathrm{c})}$} & C3 & 0.05 & 0.09 & 1.8 & 37 & 93 & 2.5 \\
\hline & B5 & 0.177 & 1.1 & 6.2 & 186 & 176 & 0.9 \\
\hline
\end{tabular}

(a) Leaf samples were collected between November 9, 1999 and March 15, 2000.

(b) For site location see Figure 8.

(c) Netted chain fern sample collected March 22, 2000. 
WSRC-TR-2001-00032, REV. 0

Table 35. Average available concentration ratios (CR-A; plant conc./available soil conc.) values.

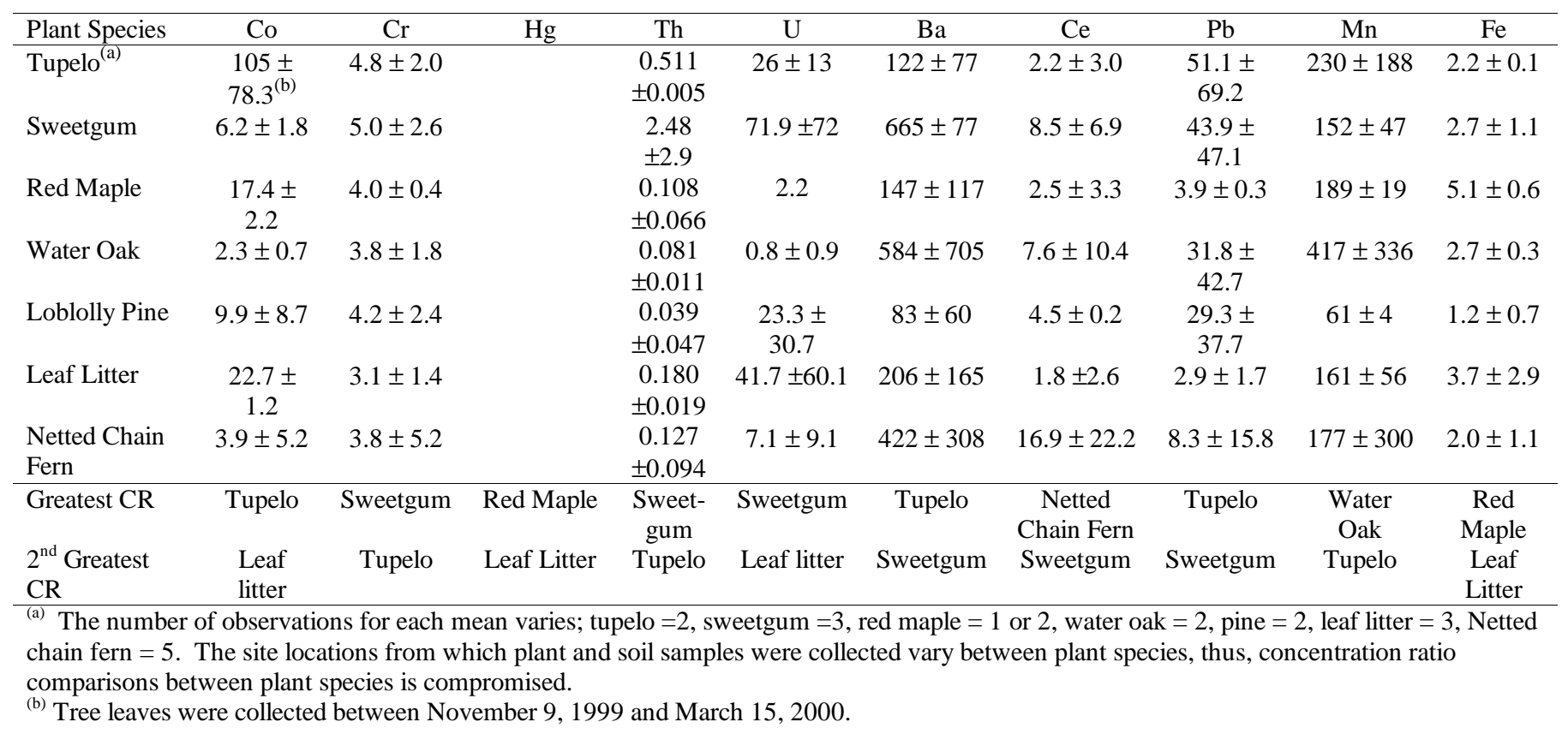




\subsection{APPENDIX B: EMAIL TRANSMISSION ENTITLED TNX OD}

CLEAN UP LEVELS, BY KAREN CONNER, 10/24/00 


\section{Karen Conner}

10/24/00 04:09 PM
To: Daniel Kaplan

cc: Tom Hinton, Dennis Stapleton, Gerald Blount, John Bennett, achlopecka@srel.edu Subject: TNXOD OU Clean-up levels

Dan,

Generally the Regulators want to see an area "cleaned up" to a human health risk level of 10-6. In the case of the TNXOD OU we have discussed using a modified Industrial Worker scenario based upon 40 days/year exposure for the Inner and Outer Swamp area or 2x average background (whichever is higher). The rest of the TNXOD OU will have to a remedial goal of 10-6 Industrial Worker based upon the typical 250 day/year exposure or $2 \mathrm{x}$ average background (whichever is higher). The COCs and 10-6 cleanup levels are as follows:

\begin{tabular}{lcc} 
Constituent & \multicolumn{1}{l}{ Inner/Outer Swamp Discharge Gully/Outfall } \\
Delta/High Ground \\
U-235 & $5.11 \mathrm{pCi} / \mathrm{g}$ & $0.816 \mathrm{pCi} / \mathrm{g}$ \\
$\mathrm{U}-233 / 234$ & $441.0 \mathrm{pCi} / \mathrm{g}$ & $68.8 \mathrm{pCi} / \mathrm{g}$ \\
$\mathrm{U}-238$ & $19.6 \mathrm{pCi} / \mathrm{g}$ & $3.13 \mathrm{pCi} / \mathrm{g}$ \\
$\mathrm{Th}-234$ & $284.0 \mathrm{pCi} / \mathrm{g}$ & $45.4 \mathrm{pCi} / \mathrm{g}$ \\
Th-232 & $604.0 \mathrm{pCi} / \mathrm{g}$ & $92.2 \mathrm{pCi} / \mathrm{g}$ \\
$\mathrm{Cs}-137$ & $0.655 \mathrm{pCi} / \mathrm{g}$ & $0.104 \mathrm{pCi} / \mathrm{g}$ \\
$\mathrm{Pb}-212$ & $4.55 \mathrm{pCi} / \mathrm{g}$ & $1.40 \mathrm{pCi} / \mathrm{g}$ \\
$\mathrm{Ra}-228$ & $1.78 \mathrm{pCi} / \mathrm{g}$ & $1.89 \mathrm{pCi} / \mathrm{g}$ \\
Th-228 & $1.60 \mathrm{pCi} / \mathrm{g}$ & $1.56 \mathrm{pCi} / \mathrm{g}$
\end{tabular}

As you can see, at these levels some of the constituents are not really a problem (e.g., Th234 and Th-232). EPA, at least, indicated they might consider a 10-5 remedial goal, which may eliminate more, but not all, of the constituents from consideration. You may want to look at how long it will take for phytoremedation at different risk levels.

The Principal Threat Source Material (PTSM) represents a cumulative risk of 10-3 based upon the default RBA for the Industrial Worker. At the TNXOD OU the PTSM is represented by Th-228, Ac-228 and Ra-228. Threshold values for PTSM are as follows:

$\begin{array}{ll}\text { Th-228 } & 35 \mathrm{pCi} / \mathrm{g} \\ \text { Ac-228 } & 66 \mathrm{pCi} / \mathrm{g} \\ \text { Ra-228 } & 66 \mathrm{pCi} / \mathrm{g}\end{array}$


From the Scoping Summaries, the total volumes, by subunit, that may require action are as follows:

Lower Discharge Gully $2500 \mathrm{~m} 3(3200 \mathrm{yd} 3)$

Outfall Delta $3750 \mathrm{~m} 3(4850 \mathrm{yd} 3)$

Inner Swamp 20,400 m3 (26,400 yd3)

High Ground $6.740 \mathrm{~m} 3(8,810 \mathrm{yd} 3)$

Outer Swamp No human health or ecological problems identified

I did not do the volume calculations (I think Cliff Cole or Coleman Miles did), so I don't know the assumptions used. I believe it is to a cleanup level of 10-6 to a depth of $4 \mathrm{ft}$, but you may want to check with them. You could use the BRA figures you already have to determine the extent (vertical and lateral) based upon the various risk levels (I don't have this readily available). The area of PTSM has not been determined - you may want to make an conservative assumption of $500 \mathrm{ft} \times 300 \mathrm{ft} \times 3 \mathrm{ft}$ deep for your calculations.

Hope this helps,

Karen Conner 
9.0 APPENDIX C: ABBREVIATED MASS-BALANCE CALCULATIONS EVALUATING PHYTOIMMOBILIZATION APPLICATION AT THE TNX OD SITE 
The results from the calculations below are presented in Section 4.7.

Table 36. Current and allowable soil activity at the study site

\begin{tabular}{cccc}
\hline Isotope & $\begin{array}{c}\text { Current } \\
\text { Soil Activity } \\
(\mathrm{pCi} / \mathrm{g})\end{array}$ & $\begin{array}{c}\text { Allowable } \\
\text { Soil Activity } \\
(\mathrm{pCi} / \mathrm{g})\end{array}$ & $\begin{array}{c}\text { Remediation } \\
\text { Required? }\end{array}$ \\
\hline Ac-228 & 5.2 & NA & NA \\
Pb-212 & 5.4 & 4.6 & Yes \\
Ra-228 & 14.5 & 1.8 & Yes \\
Th-232 & 23.8 & 604.0 & No \\
Th-228 & 21.5 & 1.6 & Yes \\
Th-234 & 169.0 & 284.0 & No \\
U-235 & 8.7 & 5.1 & Yes \\
U-233/234 & 193.0 & 441.0 & No \\
U-238 & 191.0 & 19.6 & Yes \\
(a) From Table 5.1.1, Medium Specific Exposure Point Concentrations (from Section 5, \\
RFI/RI with BRA for the TNX Outfall Delta, Lower Discharge Gully and Swamp \\
Operable Unit, WSRC-RP-98-4158, Rev. 0 Draft) \\
(b) Values form a email message from Karen Connor 10/24/00 (See Appendix B).
\end{tabular}

Table 37. Current soil inventory ( $\mathrm{I}_{\text {current soil }}$, Equation 1) of selected isotopes.

\begin{tabular}{|c|c|c|c|c|c|c|}
\hline Isotope & $\begin{array}{c}\text { Current } \\
\text { Soil Activity }^{(a)} \\
\text { (pCi/g) }\end{array}$ & $\begin{array}{c}\text { Soil } \\
\text { Density }^{(\mathrm{b})} \\
\left(\mathrm{g} / \mathrm{cm}^{3}\right)\end{array}$ & $\begin{array}{c}\mathrm{cm}^{3} \text { to } \\
\mathrm{m}^{3} \\
\text { Conversion }\end{array}$ & $\begin{array}{c}\mathrm{pCi} \text { to } \\
\mathrm{Ci} \\
\text { Conversion }\end{array}$ & $\begin{array}{c}\text { Volume } \\
\text { Contaminant } \\
\text { Site }^{(\mathrm{c})}\left(\mathrm{m}^{3}\right)\end{array}$ & $\begin{array}{c}\text { Soil } \\
\text { Inventory } \\
\text { (Ci) }\end{array}$ \\
\hline Ac-228 & 5.2 & 1.5 & $1.00 \mathrm{E}+06$ & $1.00 \mathrm{E}-12$ & 4214 & 0.033 \\
\hline $\mathrm{Pb}-212$ & 5.4 & 1.5 & $1.00 \mathrm{E}+06$ & $1.00 \mathrm{E}-12$ & 4214 & 0.034 \\
\hline Ra-228 & 14.5 & 1.5 & $1.00 \mathrm{E}+06$ & $1.00 \mathrm{E}-12$ & 4214 & 0.092 \\
\hline Th-232 & 23.8 & 1.5 & $1.00 \mathrm{E}+06$ & $1.00 \mathrm{E}-12$ & 4214 & 0.150 \\
\hline Th-228 & 21.5 & 1.5 & $1.00 \mathrm{E}+06$ & $1.00 \mathrm{E}-12$ & 4214 & 0.136 \\
\hline Th-234 & 169.0 & 1.5 & $1.00 \mathrm{E}+06$ & $1.00 \mathrm{E}-12$ & 4214 & 1.068 \\
\hline U-235 & 8.7 & 1.5 & $1.00 \mathrm{E}+06$ & $1.00 \mathrm{E}-12$ & 4214 & 0.055 \\
\hline $\mathrm{U}-233 / 234$ & 193.0 & 1.5 & $1.00 \mathrm{E}+06$ & $1.00 \mathrm{E}-12$ & 4214 & 1.220 \\
\hline U-238 & 191.0 & 1.5 & $1.00 \mathrm{E}+06$ & $1.00 \mathrm{E}-12$ & 4214 & 1.207 \\
\hline $\begin{array}{l}\text { RFI/RI with } \\
\text { Unit, WSRC } \\
\text { (b) Approxi } \\
\text { (c) Assumed }\end{array}$ & $\begin{array}{l}\text { RA for the TI } \\
\text { RP-98-4158, } \\
\text { ate density of } \\
\text { contaminated }\end{array}$ & $\begin{array}{l}\text { X Outfall } \\
\text { v. } 0 \text { Draft } \\
\text { and-textu } \\
\text { olume of }\end{array}$ & ced sedimen & $\begin{array}{l}\text { nt Concentı } \\
\text { Discharge }\end{array}$ & $\begin{array}{l}\text { tions (from } \\
\text { ully and Swa }\end{array}$ & $\begin{array}{l}\text { ion } 5, \\
\text { Operable }\end{array}$ \\
\hline
\end{tabular}


Table 38. Netted-chain fern and leaf litter activity levels $\left(\mathrm{A}_{\mathrm{plant}} i\right)$ based on soil activity $\left(\mathrm{A}_{\text {current soil }}\right)$ and concentration ratio $\left(\mathrm{CR}_{\text {plant } i}\right)$ data (Equation 2$)$.

\begin{tabular}{cccccc}
\hline Isotope & $\begin{array}{c}\text { Current } \\
\text { Soil Activity } \\
(\mathrm{pCi} / \mathrm{g})\end{array}$ & $\begin{array}{c}\text { Fern } \\
\text { Concentration } \\
\text { Ratio }^{(\mathrm{a})} \\
\text { (unitless) }\end{array}$ & Fern Activity & $\begin{array}{c}\text { Litter } \\
\text { Concentration } \\
\text { Ratio }^{(\mathrm{a})} \\
\text { (unitless) }^{\text {(pCig) }}\end{array}$ & $\begin{array}{c}\text { Leaf Litter } \\
\text { Activity } \\
\text { (pCi/g) }\end{array}$ \\
\hline Ac-228 & 5.2 & 0.25 & 1.3 & 1.80 & 9.3 \\
Pb-212 & 5.4 & 0.4 & 2.1 & 0.16 & 0.9 \\
Ra-228 & 14.5 & 29.7 & 430.7 & 21.20 & 307.4 \\
Th-232 & 23.8 & 1.1 & 26.2 & 0.01 & 0.2 \\
Th-228 & 21.5 & 1.1 & 23.7 & 0.01 & 0.2 \\
Th-234 & 169.0 & 1.1 & 185.9 & 0.01 & 1.7 \\
U-235 & 8.7 & 1.1 & 9.6 & 0.15 & 1.3 \\
U-233/234 & 193.0 & 1.1 & 212.3 & 0.15 & 29.0 \\
U-238 & 191.0 & 1.1 & 210.1 & 0.15 & 28.7 \\
\hline
\end{tabular}

(a) Fern and litter concentration ratios are based on measured values from site samples.

Table 39. Netted-chain fern and leaf-litter isotope inventory ( $\mathrm{I}_{\text {plant } i}$; Equation 3).

\begin{tabular}{lcccc}
\hline Isotope & $\begin{array}{c}\text { Netted-chain Fern } \\
\text { Activity } \\
(\mathrm{pCi} / \mathrm{g})\end{array}$ & $\begin{array}{c}\text { Leaf-litter } \\
\text { Activity } \\
(\mathrm{pCi} / \mathrm{g})\end{array}$ & $\begin{array}{c}\text { Netted-chain Fern } \\
\text { Inventory } \\
(\mathrm{Ci} / \mathrm{yr})\end{array}$ & Litter Inventory \\
$(\mathrm{Ci} / \mathrm{yr})$
\end{tabular}


Table 40. Annual contaminant reduction $\left(\mathrm{ACR}_{\mathrm{plant} i}\right.$; Equations 4 and 5) in soils as a result of plant uptake (inventory in plant/inventory in soil).

\begin{tabular}{ccccccc}
\hline Isotope & $\begin{array}{c}\text { Soil } \\
\text { Inventory } \\
(\mathrm{Ci})\end{array}$ & $\begin{array}{c}\text { Inventory } \\
\text { in Ferns } \\
(\mathrm{Ci} / \mathrm{yr})\end{array}$ & $\begin{array}{c}\text { Yearly } \\
\text { Percentage } \\
\text { Removed (\%) }\end{array}$ & $\begin{array}{c}\text { Inventory } \\
\text { in Litter } \\
(\mathrm{Ci} / \mathrm{yr})\end{array}$ & $\begin{array}{c}\text { Yearly } \\
\text { Percentage } \\
\text { Removed (\%) }\end{array}$ & $\begin{array}{c}\text { Total } \\
\text { Percentage } \\
\text { Removed (\%) }\end{array}$ \\
\hline $\mathrm{Ac}-228$ & 0.033 & $1.67 \mathrm{E}-06$ & $0.005 \%$ & $9.70 \mathrm{E}-05$ & $0.296 \%$ & $0.301 \%$ \\
$\mathrm{~Pb}-212$ & 0.034 & $2.77 \mathrm{E}-06$ & $0.008 \%$ & $8.92 \mathrm{E}-06$ & $0.026 \%$ & $0.035 \%$ \\
$\mathrm{Ra}-228$ & 0.092 & $5.57 \mathrm{E}-04$ & $0.607 \%$ & $3.20 \mathrm{E}-03$ & $3.489 \%$ & $4.096 \%$ \\
$\mathrm{Th}-232$ & 0.150 & $3.38 \mathrm{E}-05$ & $0.022 \%$ & $2.48 \mathrm{E}-06$ & $0.002 \%$ & $0.024 \%$ \\
Th-228 & 0.136 & $3.06 \mathrm{E}-05$ & $0.022 \%$ & $2.24 \mathrm{E}-06$ & $0.002 \%$ & $0.024 \%$ \\
Th-234 & 1.068 & $2.40 \mathrm{E}-04$ & $0.022 \%$ & $1.76 \mathrm{E}-05$ & $0.002 \%$ & $0.024 \%$ \\
$\mathrm{U}-235$ & 0.055 & $1.24 \mathrm{E}-05$ & $0.022 \%$ & $1.36 \mathrm{E}-05$ & $0.025 \%$ & $0.047 \%$ \\
$\mathrm{U}-233 / 234$ & 1.220 & $2.74 \mathrm{E}-04$ & $0.022 \%$ & $3.01 \mathrm{E}-04$ & $0.025 \%$ & $0.047 \%$ \\
$\mathrm{U}-238$ & 1.207 & $2.72 \mathrm{E}-04$ & $0.022 \%$ & $2.98 \mathrm{E}-04$ & $0.025 \%$ & $0.047 \%$ \\
\hline
\end{tabular}

Table 41. Total inventory allowed based on $10 \mathrm{e}-6$ risk.

\begin{tabular}{cccc}
\hline Isotope & $\begin{array}{c}\text { Allowable } \\
\text { Soil Activity } \\
\text { (pCi) } / \mathrm{g})\end{array}$ & $\begin{array}{c}\text { Allowable Soil } \\
\text { Inventory } \\
\text { (Ci) }\end{array}$ & $\begin{array}{c}\text { Current Soil } \\
\text { Inventory } \\
(\mathrm{Ci})\end{array}$ \\
\hline $\mathrm{Ac}-228$ & $\mathrm{NA}$ & $\mathrm{NA}$ & 0.0327 \\
$\mathrm{~Pb}-212$ & 4.6 & 0.0285 & 0.0339 \\
$\mathrm{Ra}-228$ & 1.8 & 0.0112 & 0.0917 \\
Th-232 & 604.0 & 3.7853 & 0.1504 \\
Th-228 & 1.6 & 0.0100 & 0.1359 \\
Th-234 & 284.0 & 1.7798 & 1.0682 \\
U-235 & 5.1 & 0.0320 & 0.0552 \\
U-233/234 & 441.0 & 2.7637 & 1.2200 \\
U-238 & 19.6 & 0.1228 & 1.2073 \\
\hline
\end{tabular}

(a) Allowable soil activity data was suggested by Karen Conner in email transmission dated 10/24/00 (Appendix B)

(b) Volume of contaminated site $=500 \times 300 \times 1 \mathrm{ft}=150,000 \mathrm{ft}^{3}=4214 \mathrm{~m}^{3}$.

(c) Soil bulk density $=1.5 \mathrm{~g} / \mathrm{cm}^{3}$.

(d) Equation 1. 
WSRC-TR-2001-00032, REV. 0 


\subsection{DISTRIBUTION}

B. P. Allen

N. C. Bell

J. T. Bennett

G. C. Blount

R. F. Blundy

K. E. Brewer

B. T. Butcher

S. E. Campbell

K. R. Conner

T. G. Hinton

D. I. Kaplan

A. S. Knox

E. M. McNamee

L. Newman

S. M. Serkiz

R. R. Sharitz

D. L. Stapleton

ERD Document Control

STI

WPT File
Bld. 737A, SREL

Bld. 730-2B, Rm. 1089

Bld. 730-2B, Rm. 2174

Bld. 730-2B, Rm. 2179

Bld. 730-2B, Rm. 2003

Bld. 730-2B, Rm. 3141

Bld. 773-43A, Rm. 216

Bld. 773-2B, Rm. 2170

Bld. 730-2B, Rm. 1099

Bld. 737A, SREL

Bld. 773-43A, Rm. 215

Bld. 737A, SREL

Bld. 730-2B, Rm. 218

Bld. 737A, Rm 215

Bld. 773A, Rm. B121

Bld. 737A, SREL

Bld. 730-2B, Rm. 2151

Project Files, CA1129

703-43A (4 copies)

773-43A, Rm. 213 